\title{
INVOLVEMENT OF THE PAIRED-DOMAIN TRANSCRIPTION FACTOR PAX6 IN THE REgULATION OF GLUCAGON GENE TRANSCRIPTION BY INSULIN
}

\section{Dissertation}

zur Erlangung des Doktorgrades der Mathematisch-Naturwissenschaftlichen Fakultäten der Georg-August-Universität zu Göttingen

vorgelegt von

\section{Rafal Grzeskowiak}

Aus Szczecin / Polen 
Diese Arbeit wurde in der Abteilung Molekulare Pharmakologie am Zentrum Pharmakologie und Toxikologie der Georg-August-Universität Göttingen angefertigt.

Die Untersuchungen wurden durch Mittel des Graduiertenkollegs 335 unterstützt.

Teile der Arbeit wurden bereits veröffentlicht:

Grzeskowiak R, Amin J, Oetjen E, and Knepel W (2000) Insulin Responsiveness of the Glucagon Gene Conferred by Interactions between Proximal Promoter and More Distal Enhancer-like Elements Involving the Paired-domain Transcription Factor Pax6. J Biol Chem, in press

Beimesche S, Neubauer A, Herzig S, Grzeskowiak R, Diedrich T, Cierny I, Scholz D, Alejel T, and Knepel W (1999) Tissue-specific transcriptional activity of a pancreatic islet cell-specific enhancer sequence/Pax6-binding site determined in normal adult tissues in vivo using transgenic mice. Mol Endocrinol 13:718-28

D7

Referent: Prof. Dr. R. Hardeland

Korreferent: Prof. Dr. K. Jungermann

Tag der mündlichen Prüfung: $\quad 31.10 .2000$ 


\section{CONTENTS}

CONTENTS

FIGURES AND TABLES

\section{INTRODUCTION}

1.1 Glucagon in diabetes mellitus

1.2 The insulin signalling pathway

1.3 Glucagon and pancreatic islet

1.4 Expression of the glucagon gene

1.5 The glucagon promoter

1.7 The aim of the study

2. MATERIALS AND METHODS

2.1 Chemicals

2.2 Radiochemicals

2.3 Antibiotics and protease inhibitors

2.4 Enzymes and kits

2.5 Bacterial culture materials

2.6 Eukariotic cell culture materials

2.7 Filters and separation columns

2.8 Buffers and media 
$\begin{array}{ll}2.9 \text { Oligonucleotides } & 15\end{array}$

$\begin{array}{ll}P C R \text { primers } & 15\end{array}$

$\begin{array}{ll}R T \text {-PCR primers } & 15\end{array}$

Sequencing primers $\quad 15$

EMSA oligonucleotide probes 16

2.10 Reporter gene plasmids $\quad 16$

$\begin{array}{ll}2.11 \text { Expression plasmids } & 17\end{array}$

2.12 Bacterial strains $\quad 19$

2.13 Eukariotic cell lines

2.14 Tissue collection 19

2.15 Antisera and antibodies $\quad 19$

2.16 Molecular weight standards $\quad 19$

DNA standards 19

Protein standards 19

2.17 Standard methods for handling DNA/RNA 20

$\begin{array}{ll}\text { Sterilisation } & 20\end{array}$

$\begin{array}{ll}\text { Phenol-chloroform extraction } & 20\end{array}$

DNA/RNA precipitation $\quad 20$

Dialysis $\quad 20$

$\begin{array}{ll}\text { Annealing of single-stranded DNA oligonucleotides } & 21\end{array}$

Radioactive labelling of DNA oligonucleotides by Klenow reaction 21

Estimation of nucleic acids concentration 22

$2.18 \mathrm{Gel}$ electrophoresis $\quad 22$

Agarose gel electrophoresis 22

Purification of DNA fragments from agarose gel 22

Autoradiography 23

2.19 RT-PCR 24

2.20 Enzymatic modification of DNA 26

"Addition of single A" 26

$\begin{array}{ll}\text { Endonuclease restriction } & 26\end{array}$

Ligation of DNA fragments $\quad 27$

2.21 Standart methods of molecular cloning 27

Preparation of competent E.coli bacteria 27 
$\begin{array}{ll}\text { Transformation of competent bacteria } & 28\end{array}$

$\begin{array}{ll}\text { Mini preparation of plasmid DNA } & 28\end{array}$

Maxi preparation of plasmid DNA 29

2.22 DNA sequencing 30

Sequencing reaction $\quad 30$

Sequencing polyacrylamide gel electrophoresis 32

2.23 RNA isolation from animal tissues

2.24 Protein expression in bacteria 33

2.25 Extraction of nuclear proteins (Schreiber-Schaffner Method) 36

2.26 SDS-polyacrylamid gel electrophoresis 37

2.27 Western blot analysis 39

2.28 EMSA (Electro-Mobility Shift Assay) 41

Binding reaction 41

Non-denaturating gel electrophoresis $\quad 42$

2.29 Eukariotic cells culture methods $\quad 43$

Cell culture 43

DEAE-dextran transfection 43

Calcium phosphate transfection 44

The insulin treatment 45

Cell extract preparation 46

Luciferase reporter gene assay 46

$\begin{array}{ll}\text { GFP reporter gene assay } & 47\end{array}$

2.30 Software $\quad 48$

\section{RESULTS}

3.1 The constructs generated in this study 49

3.2 Pax6 gene expression in pancreatic islets as revealed by RT-PCR 50

3.3 Inhibition by insulin of Pax6-mediated transcriptional

activity in InR1-G9 cells

Inhibition by insulin of transcriptional activity

conferred by Pax6 binding site (G3A) from the glucagon promoter

Inhibition by insulin of Pax6-mediated

activity as revealed in GAL4/viral E1B system 
3.4 Requirement of Pax6 for inhibition of glucagon gene transcription by insulin in InR1-G9 cells

Effect of overexpression of the Pax6 paired domain 55

Effect of mutations of the Pax6-binding sites within the glucagon promoter 56

Restoration of the transcriptional activity and insulin responsiveness of the mutated glucagon promoter by overexpression of GAL4-Pax6 58

3.5 DNA-binding and electro-phoretic mobililty of Pax6 proteins after insulin treatment in InR1-G9 cells 59

Effect of insulin treatment on Pax6 DNA binding as revealed by EMSA 59

Effect of insulin on Western blot analysis of

Pax6 protein after insulin treatment

3.6 Effect of a mutation of extracellular signal-regulated kinase (ERK) and p38 kinase sites within the Pax6 transactivation domain on the regulation by insulin

3.7 Effect of insulin on CBP-mediated transcriptional activity

Effect of insulin on GAL4-CBP activity in the context of the glucagon promoter but not in the context of viral E1B promoter

Effect of insulin on transcriptional activity conferred by

$\mathrm{N}$-terminal and $\mathrm{C}$-terminal part of $\mathrm{CBP}$

Mapping the insulin responsive domain within

the $C$-terminal part of $C B P$

Effect of overexpression of the constitutively active protein kinase

$B$ (myrPKB) on the activity of the glucagon promoter

and activity conferred by $C B P$

\section{DISCUSSION}

4.1 The involvement of Pax6 in the regulation of glucagon gene transcription by insulin

4.2 Regulation of Pax6 activity by insulin-induced signalling pathways 72

4.3 Inhibition by insulin of the CBP-mediated transcriptional activity $\quad \mathbf{7 4}$

4.4 Defining the insulin responsive region of CBP 75

4.5 Regulation of CBP activity by PKB 76 
4.6 Final concept: Inhibition of glucagon gene transcription by insulin through IRE-binding factor (IRF) independent mechanism

REFERENCES 80 


\section{FIGURES AND TABLES}

Fig. 1 Insulin signalling pathway.

Fig. $2-350$ bp region of the rat glucagon gene with indicated regulatory DNA elements and their transcription factors.

Fig. 3 Pax6 cDNA. 9

Fig. 4 Pax6 gene expression in mouse pancreas as revealed by RT-PCR. $\quad 50$

Fig. 5 Effect of insulin on the transcriptional activity conferred by the Pax6 binding site (G3A).

Fig. 6 Inhibition by insulin of Pax6 transcriptional activity as determined using the GAL4 system.

Fig. 7 Lack of inhibition by insulin of GAL4-Pax6 expression as revealed by electrophoretic mobility shift assay.

Fig. 8 Lack of inhibition by insulin of GAL4-Pax6 expression as revealed by Western blotting.

Fig. 9 Effect of overexpression of the Pax6 paired domain on insulin responsiveness.

Fig. 10 Schematic representation of the wild-type and mutated glucagon reporter genes.

Fig. 11 Basal activity and insulin responsiveness of the mutant glucagon reporter genes.

Fig. 12 Overexpression of GAL4-Pax6 restores basal activity and insulin responsiveness of glucagon gene transcription after mutation of the Pax6 binding sites into GAL4 binding sites.

Fig. 13 Effect of insulin treatment on Pax6 DNA binding. 60

Fig. 14 Western blot analysis of Pax6 after insulin treatment.

Fig. 15 Mutation of p38/ERK phosphorylation sites within Pax6 transactivation domain does not abolish negative regulation by insulin. 62 
Fig. 16 Inhibition by insulin of GAL4-CBP activity in the context of the glucagon promoter.

Fig. 17 Schematic representation of the CBP protein.

Fig. 18 Insulin inhibition of transcriptional activity conferred by the $\mathrm{N}$ - and $\mathrm{C}$-terminal parts of $\mathrm{CBP}$.

Fig. 19 Mapping the insulin responsive domain within the C-terminal part of CBP.

Fig. 20 Inhibition of GAL4-CBP activity by myrPKB overexpression.

Fig. 21 The importance of Pax6 and CBP in the insulin responsiveness of the glucagon promoter.

Tab. 1. Reporter gene constructs, which were used in this work and were not prepared.

Tab. 2. Expression constructs, which were used in this work and were not prepared.

Tab. 3. PCR temperature profiles.

Tab. 4. Temperature profiles of the cyclic sequencing reactions.

Tab. 5. List of the constructs generated in this study. 


\section{ABBREVIATIONS}

$\begin{array}{ll}\text { Ab. } & \text { antibody } \\ \text { A } & \text { adenine } \\ \text { Abs. } & \text { absolute } \\ \text { Ac } & \text { acetate } \\ \text { Amp } & \text { ampicillin } \\ \text { Ampuwa } & \text { aqua ad injectabilia } \\ \text { APS } & \text { ammonium persulfate } \\ \text { BAD } & \text { bcl-xl/bcl-2-associated in death } \\ \text { BHK } & \text { baby hamster kidney cells } \\ \text { BSA } & \text { bovine serum albumin } \\ \text { Bp } & \text { base pair } \\ \text { C } & \text { cytosine } \\ { }^{\circ} \text { C } & \text { celsius grade } \\ \text { CA } & \text { chloramphenicol } \\ \text { CAT } & \text { chloramphenicol-acetyl-transferase } \\ \text { cAMP } & \text { cyclic adenosine-3',5'-monophosphate } \\ \text { cDNA } & \text { dideoxy-ribonucleoside-triphosphate } \\ \text { Ci } & \text { copy deoxyribonucleic acid } \\ \text { CMV } & \text { curie } \\ \text { Cpm } & \text { cytomegalo virus } \\ \text { CRE } & \text { counts per minute } \\ \text { CsCl } & \text { cesium chloride } \\ \text { dATP } & \text { deoxyadenosine-5'-triphosphate } \\ \text { dCTP } & \text { deoxycytidine-5'-triphosphate } \\ \text { dd } & \text { dide }\end{array}$




\begin{tabular}{|c|c|}
\hline DEPC & diethylpyrocarbonate \\
\hline dGTP & deoxyguanosine-5'-triphosphate \\
\hline DMEM & Dulbecco's modified eagle medium \\
\hline DMSO & dimethylsulfoxide \\
\hline DNA & deoxyribonucleic acid \\
\hline DNAse & deoxyribonuclease \\
\hline dNTP & deoxynucleoside-5'-triphosphate \\
\hline DTT & dithiothreitol \\
\hline DTTP & deoxythymidine-5'-triphosphate \\
\hline E. coli & Escherichia coli \\
\hline EDTA & ethylendiamine-tetra-acetic acid \\
\hline EMSA & electrophoretic mobility shift assay \\
\hline ERK & externally regulated kinase \\
\hline FCS & fetal calf serum \\
\hline $\mathrm{FKH}-4$ & forkhead-4 \\
\hline FKHR & forkhead-related \\
\hline$g$ & gram \\
\hline G & guanine \\
\hline GCG & genetics computer groups \\
\hline GFP & green fluorescent protein \\
\hline GSK3 & glycogen synthase kinase 3 \\
\hline GST & glutathione S-transferase \\
\hline $\mathrm{h}$ & hour or hours \\
\hline Hepes & 2-(-4-2-hydroxyethyl)-piperazinyl---ethansulfonate \\
\hline HBS & hepes-buffered saline \\
\hline HIT & hamster insulinoma tumor cell line \\
\hline HNF-3 & hepatocyte nuclear factor-3 \\
\hline IRE & insulin-responsive element \\
\hline IRS & insulin receptor substrate \\
\hline IPTG & isopropyl-thio-galactoside \\
\hline Kan & kanamycin \\
\hline $\mathrm{Kb}$ & kilobases \\
\hline
\end{tabular}




\begin{tabular}{|c|c|}
\hline $\mathrm{kDa}$ & kilodalton \\
\hline KP-Buffer & potassium phosphate buffer \\
\hline$L$ & liter \\
\hline LB & laura bertani \\
\hline MAPK & mitogen-activated protein kinase \\
\hline$\beta-\mathrm{ME}$ & $\beta$-mercaptoethanol \\
\hline MEK & MAPK/ERK kinase \\
\hline $\min$ & minute or minutes \\
\hline MOPS & 3-(N-morpholino)-propansulfonic acid \\
\hline mRNA & messenger ribonucleic acid \\
\hline $\mathrm{mw}$ & molecular weight \\
\hline $\mathrm{NaAc}$ & sodium acetate \\
\hline $\mathrm{NaOH}$ & sodium hydroxide \\
\hline NFAT & nuclear factor of activated t-cells \\
\hline OD & optical density \\
\hline $\mathrm{Pa}$ & pascale \\
\hline PAGE & polyacrylamide gel electrophoresis \\
\hline PBS & phosphate-buffered saline \\
\hline $\mathrm{Pbx}$ & pre-b-cell-homeobox-protein \\
\hline PCR & polymerase chain reaction \\
\hline PEG & polyethylenglycol \\
\hline PDK & phosphatidylinositol-triphosphate-dependent kinase \\
\hline $\mathrm{PH}$ & plekstrin homology \\
\hline $\mathrm{Pl}$ & phosphatidylinositol \\
\hline $\mathrm{PI}-3-\mathrm{K}$ & phosphatidylinositol -3-OH-kinase \\
\hline PISCES & pancreatic islet cell-specific enhancer sequence \\
\hline $\mathrm{PKB}$ & protein kinase B \\
\hline PMSF & phenylmethyl-sulfonylfluoride \\
\hline Prep1 & pbx-regulating protein 1 \\
\hline RNA & ribonucleic acid \\
\hline RNase & ribonuclease \\
\hline $\mathrm{RT}$ & room temperature / reverse transcription \\
\hline
\end{tabular}




\begin{tabular}{|c|c|}
\hline RTK & receptor tyrosine kinase \\
\hline RT-PCR & reverse transcriptase polymerase chain reaction \\
\hline Tth & Thermus thermophilus \\
\hline Sec & second \\
\hline SDS & sodium-dodecyl-sulfate \\
\hline SEM & standard error of the mean \\
\hline SP6 & bacteriophage sp6 \\
\hline $\mathrm{T}$ & thymine \\
\hline $\mathrm{T} 7$ & bacteriophage T7 \\
\hline Tab. & table \\
\hline TAE & tris-acetate-EDTA \\
\hline TBE & tris-borate-EDTA \\
\hline TBS & tris-buffered saline \\
\hline TE & tris-EDTA \\
\hline TEMED & N', N', N', N'-tetramethyldiamine \\
\hline TK & thymidine kinase \\
\hline Tris & tris-(hydroxymethyl)-aminomethane \\
\hline Tween 20 & polyoxyethylen-sorbit-monolaurate \\
\hline U & unit (enzymatic activity) \\
\hline RPM & rotations per minute \\
\hline UV & ultraviolet \\
\hline $\mathrm{V}$ & volt \\
\hline Vol. & volume \\
\hline $\mathrm{V} / \mathrm{v}$ & volume per volume \\
\hline W & watt \\
\hline$W / v$ & weight per volume \\
\hline X-Gal & 5-bromo-4-chloro-3-indolyl-o-d-galactoside \\
\hline
\end{tabular}




\section{SUMMARY}

Regulation of gene transcription is an important aspect of insulin's action. However, the mechanisms involved are poorly understood. Insulin inhibits glucagon gene transcription and insulin deficiency is associated with hyperglucagonemia that contributes to hyperglycemia in diabetes mellitus.

In the present study transient transfection analysis in a glucagon-producing pancreatic islet cell line was performed, where the activity of an artificial minienhancer consisting of synergizing Pax6 binding sites (G3A) in front of a heterologous promoter, as well as Pax6 activity when assessed using a GAL4/viral E1B system, were inhibited by insulin. This provides evidence that Pax6 can confer negative regulation by insulin in pancreatic islets.

Furthermore, Pax6 seems to play a critical role in the insulin responsiveness of the glucagon promoter because the overexpression of the Pax6 paired domain as well as the mutation of the Pax6 binding sites within the glucagon promoter element G1 and G3 markedly reduced basal activity and insulin responsiveness. The expression of GAL4-Pax6 and GAL4-VP16 restored basal activity of the doubly mutated promoter, whereas only GAL4-Pax6 restored also insulin responsiveness.

When the potential Pax6 coactivator CBP was fused to the GAL4 DNA-binding domain, the GAL4-CBP activity was inhibited by insulin within the glucagon promoter context but not in front of the viral E1B promoter. Fusing $\mathrm{N}$-, C-terminal and middle parts of CBP with the GAL4 domain only the $\mathrm{N}$ - and C-terminal part conferred transcriptional activity and insulin responsiveness. Further mapping of the C-terminal of CBP revealed a single region between aminoacids 2040 and 2170 sufficient to confer the negative regulation by insulin. The activity conferred by this region as well as by the $\mathrm{N}$-terminal part of $\mathrm{CBP}$ was inhibited by the overexpression of the constitutively active form of PKB, myrPKB.

The results of present study suggest that the paired domain transcription factor Pax6 is required for insulin responsiveness of the glucagon promoter. They also 
indicate that the Pax6-interacting coactivator CBP might be involved in this process. It is finally speculated that within the specific context of the glucagon promoter a nucleoprotein complex is being induced with Pax6 and CBP as critical components. Insulin-induced signalling pathways might target this large, glucagon promoterspecific protein complex rather than any single transcriptional factor and therefore act through a IRE-binding factor (IRF)-independent mechanism. 


\section{INTRODUCTION}

The regulation of gene transcription by insulin is an important facet of this hormone's action. Insulin has been shown to stimulate or inhibit the transcription of a large number of genes (O'Brien and Granner 1996). Based on the hormone response element paradigm, there has long been speculation that the effects of insulin are mediated through a common insulin-responsive element (IRE) and binding transcription factor (Alexander-Bridges et al. 1992, O'Brien and Granner 1991, O'Brien et al. 1990). IREs have been characterized in a number of genes but, unlike CAMP, which regulates gene transcription predominantly through one cis-acting element, the CRE (Meyer and Habener 1993), it became apparent that a single consensus IRE does not exist (O'Brien and Granner 1996, Chapman et al. 1999). Likewise, diverse transcription factors have been suggested to mediate the insulin response, including AFX (Kops et al. 1999), FKHRL1 (Brunet et al. 1999), FKHR (Durham et al. 1999), GABP (Ouyang et al. 1996), Fra-2/Jun D (Chapman et al. 1999, Streeper et al. 1998), Egr-1 (Barroso and Santisteban 1999), NF-1 (Ortiz et al. 1999), USF (Wang and Sul 1997), IRE-ABP (Alexander-Bridges et al. 1992), and SRF (Thompson et al. 1994). On the other hand, it has also been suggested that insulin may act independently of an IRE and target arrays of interacting transcription factors at the coactivator level (Leathy et al. 1999, Pierreux et al. 1999, Pierreux et al. 1998).

The genes that are negatively regulated by insulin include the one encoding glucagon (Philippe 1989).

\subsection{Glucagon in diabetes mellitus.}

Diabetes mellitus is one of the most prevalent disease in the Western world, affecting 3 to $5 \%$ of the population of Europe and Northern America and about 100 million world-wide (Cohen et al. 1997). Apart from insulin deficiency diabetes is also characterised by high glucagon levels. The key biological actions of glucagon converge on regulation of glucose homeostasis: glucagon stimulates glucose 
production by glycogen breakdown and gluconeogenesis in the liver (Unger and Orci 1981, Lefébvre 1995). Secretion of glucagon is inhibited by insulin and glucagon functions as a counterregulatory hormone, opposing the actions of insulin, and maintaining the levels of blood glucose. Therefore in insulin-deficient patients with diabetes, excess glucagon secretion plays an essential role in the metabolic perturbations associated with diabetes, such as hyperglycaemia (Unger and Orci 1981, Philippe 1989, Lefébvre 1995, Shah et al. 1999). Hence mechanisms of inhibition by insulin of glucagon secretion and gene transcription present an important and useful target for medical intervention in treating diabetics with insulin deficiency.

\subsection{The insulin signalling pathway.}

The recent years have seen great advance in the understanding of initial steps in insulin signalling pathway (Fig. 1). Insulin initiates its pleiotropic effects by binding to its specific, cell surface receptor, the insulin receptor (Kasuga et al. 1982). Insulin binding leads to the autophosphorylation of the insulin receptor and activation of the receptor tyrosine kinase (RTK), which in turn leads to the phosphorylation of endogenous substrates (Kasuga et al.1982). Direct substrate for the insulin RTK are molecules of insulin receptor substrates (IRS) (Kellerer et al.1999), which are phosphorylated by the RTK on numerous tyrosine residues. The phospho-tyrosines of the IRS serve as docking sites for many signalling molecules (Cheatham and Kahn 1995). One of the proteins binding to IRS is PI-3-OH-kinase (PI-3-K). Binding to the IRS activates PI-3-kinase, which in turn phosphorylates membrane inositol lipids at the 3' position of the inositol ring to generate the 3-phosphoinositides: $\mathrm{PI}(3) \mathrm{P}$, $\mathrm{PI}(3,4) \mathrm{P}_{2}$ and $\mathrm{PI}(3,4,5) \mathrm{P}_{3}$ (Vanhaesebroeck et al.1997). One of the well-established targets of PI-3-K activation is the Ser/Thr protein kinase B (PKB). PKB is thought to bind through its pleckstrin homology domain $(\mathrm{PH})$ to the 3-phosphoinositides, which leads to PKB recruitment to the plasma membrane and also contributes to its activation (Downward 1998). In response to insulin and growth factors PKB becomes phosphorylated at two major sites, Thr308 and Ser473 (Alessi et al.1996), which results in its activation (Alessi et al.1997, Stokoe et al.1997). Two kinases responsible for this phosphorylation have been recently identified and termed PDK1 and PDK2 (Alessi et al.1997). The first direct in vivo substrate of PKB to be identified 
was GSK3 (Cross et al.1995), which upon phosphorylation by PKB is inactivated, and this leads to activation of glycogen synthesis, an important feature of insulin action on the metabolism (Shaw et al.1997). Another target for PKB is the ribosomal protein S6 kinase (p70 ${ }^{\mathrm{S} 6 \mathrm{~K}}$ ) (Burgering and Coffer 1995), and the 6-phosphofructo-2kinase (PFK-2) (Deprez et al.1997). Recent reports reveal that PKB is also involved in protecting cells from apoptosis, and in promoting cell survival by phosphorylating the pro-apoptotic Bcl-2 family member, BAD (Datta et al.1997).

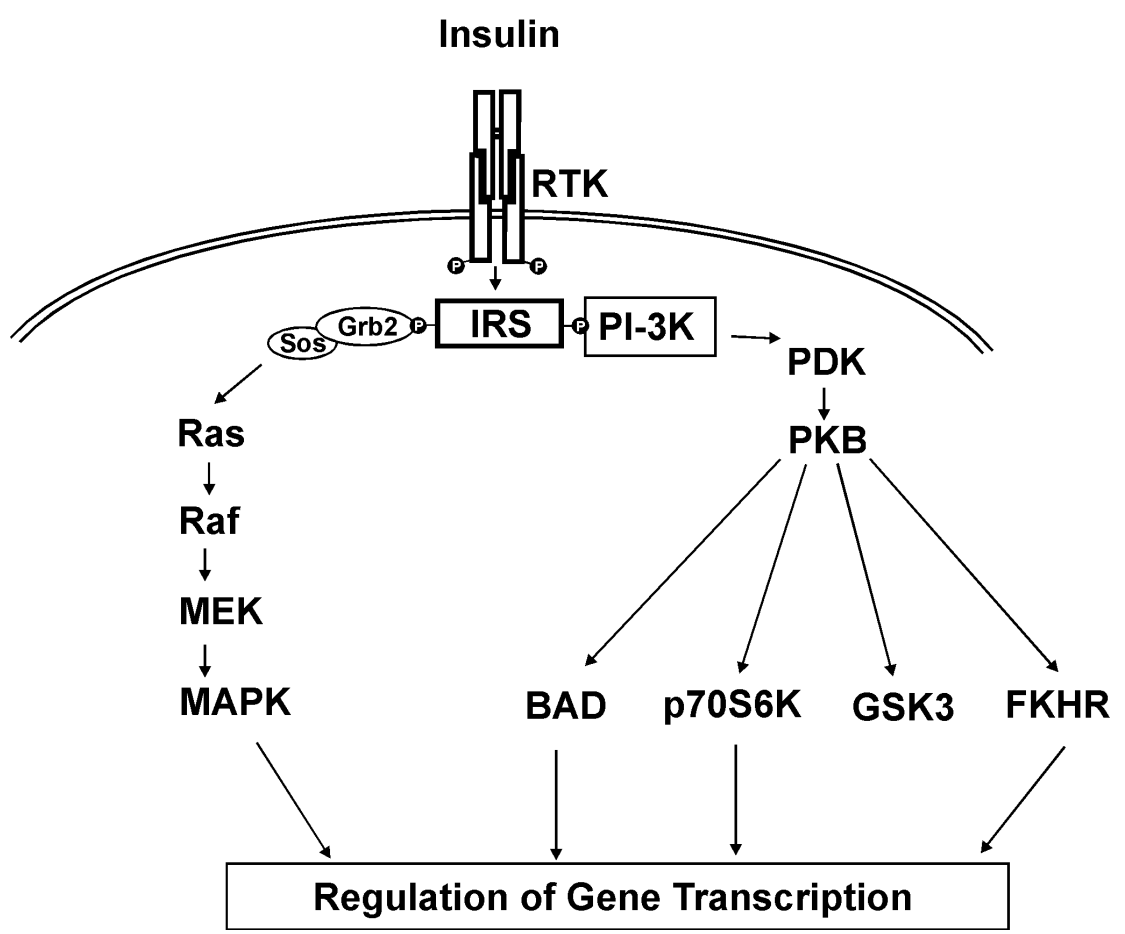

Fig. 1. Insulin signalling pathway. (See the text for further details).

Insulin can act also through another, ras/MAP-dependent pathway (Fig. 1). In this pathway growth factor receptor-bound protein 2 (GRB-2) links IRS to the guanine nucleotide exchange protein Sos, which activates p21 $1^{\text {ras }}$ (Cheatham and Kanh 1995). Ser/Thr protein kinase Raf- 1 is a direct target of activated $\mathrm{p} 21^{\text {ras }}$, and Raf- 1 has been demonstrated to phosphorylate and activate MAP kinase-kinases (MAPKK or MEK) (Kyriakis 1992), which then activate MAP kinases. 


\subsection{Glucagon and pancreatic islet.}

Glucagon is a 29-amino acid peptide hormone. It is a member of a structurally related group of peptides which include secretin (Mutt et al.1970), vasoactive intestinal peptide (Mutt and Said 1974), gastric inhibitory peptide (Brown 1971), and growth hormone-releasing hormone (Spiess et al.1982). Glucagon is produced and secreted by the A cell of the pancreatic islets (Unger and Orci 1981, Orskov et al.1986) and its secretion is regulated by blood levels of glucose (Gerich et al.1976), and amino acids (Assan et al.1977) as well as a variety of hormonal stimuli (Samols et al.1983). The pancreatic islet is a highly specialised endocrine organ with a specific structure. Insulin-secreting B-cells (60\% of the islet) form the core of the islet, whereas A-cells $(25 \%)$ form the outer rim. Somatostatin-producing D-cells and pancreatic peptideproducing PP-cells are dispersed between A and B cells and constitute about $10 \%$ of islet mass (Bonner-Weir et al.1991, Thews et al.1991, Slack 1995). This highly organised structure is believed to be crucial for properly co-ordinated secretion of pancreatic hormones and reflects functional interrelations between them. B-cells in the islet centre produce insulin, which directly acts on the A-cells where it inhibits glucagon secretion. In this tightly co-ordinated biologic system antagonist hormones are regulated in autocrine, paracrine, nervous and metabolic way: somatostatin inhibits insulin and glucagon secretion, glucagon on the other hand stimulates secretion of insulin and somatostatin (Reichlin 1983).

\subsection{Expression of the glucagon gene.}

The glucagon gene is mainly expressed in the A-cell of the endocrine pancreas (Unger and Orci 1981, Habener et al.1991), intestinal L-cells (Drucker 1998), few neurons in the brain (Drucker and Asa 1988) and at low levels in the thymus (Throsby et al.1998). The resulting proglucagon peptide is processed differentially in these tissues (Drucker and Asa 1988, Habener et al.1991, Drucker 1998), giving rise to glucagon in the pancreatic A cells, glucagon-like peptide 1 (GLP-1), GLP-2, and oxyntomodulin in the intestinal L-cells, which are implicated in the regulation of insulin secretion, stimulation of intestinal epithelium proliferation and glucose absorption in the intestine, respectively (Drucker 1998). In the brain GLP-1 is formed that was suggested to play a role in the control of feeding and in the action of leptin (Drucker 1998). 


\subsection{The glucagon promoter.}

The molecular mechanism of inhibition of glucagon gene transcription by insulin is poorly understood. It has been demonstrated that in pancreatic islets the level of glucagon mRNA is negatively regulated by insulin (Philippe 1989) and 350 base pairs of the 5'-flanking region of the rat glucagon promoter are sufficient to confer the insulin responsiveness in the glucagon producing islet cell line InR1-G9 (Philippe 1991). It has been also proposed that an enhancer-like element G3 functions as an IRE of the glucagon gene (Philippe 1991). However, recently a 5'-, 3'-, and internal deletion analysis and oligonucleotide cassette insertions failed to identify a single insulin-responsive element in the glucagon gene (Grzeskowiak et al. 2000). Consequently, it was proposed that insulin responsiveness depends on the presence of both proximal promoter elements and more distal enhancer-like elements (Grzeskowiak et al. 2000).

During the last decade, by deletional, linker-scanning and DNase I footprint analyses, major cis-regulatory elements in the -350 region of the glucagon promoter have been identified. It was possible in many instances to characterise also transacting nuclear proteins (Fig. 2) (Philippe et al.1988, Lee et al.1992, Knepel et al.2000). Within these elements two groups can be distinguished: proximal promoter elements encompassing $\mathrm{G} 1$ and $\mathrm{G} 4$, and so called more distal enhancer-like elements: G2, G3 and CRE. The proximal promoter region (base pairs -136 to +58 ) confers on its own low transriptional activity, however is required to mediate activation of transcription by enhancer elements $\mathrm{G} 2$ and G3, and may play a role in restricting transcription to cell lines with A-cell phenotype (Philippe et al. 1988, Morel et al. 1995). The proximal promoter element $\mathrm{G} 1$ (base pairs -97 to -65 ) contains AT-rich motifs (Morel et al.1995), which have been demonstrated to bind homeodomain-containing transcription factors. These include LIM homeodomain protein IsI-1 (Wang and Sul 1995), the caudal-related homeodomain protein cdx-2/3 (James et al.1994, Jin and Drucker 1996, Laser et al.1996) and the POU domain transcription factor brain-4 (Hussain et al.1997). In addition to Isl-1, cdx-2/3 and brain-4, also the transcription factor Pax6 binds to the G1 element (Fig.2 and 3). Pax6 contains two DNA-binding domains: a homeodomain and a paired domain. Pax6 binding to $G 1$ was shown to regulate positively transcription of the glucagon gene in a synergistic way with cdx-2/3 (Andersen et al.1999, Ritz-Laser et al.1999). 
Next to the G1 element is a region called G4 (-150 to $-91 \mathrm{bp})$ containing sites binding $\mathrm{Pdx} 1$, the basic region helix-loop-helix proteins E2A (E12/E47/E2/5) and Beta2 (Neuro D) (Kruse et al.1993). Further upstream are located two enhancer like elements: G2 (-192 to $-174 \mathrm{bp})$ and G3 (-264 to $-238 \mathrm{bp}$ ), which display islet-specific enhancer-like properties inasmuch as they enhance expression in some phenotypically distinct pancreatic islet cell lines but not in several nonislet cell lines. G2-binding transcriptional factors include Hepatocyte Nuclear Factor (HNF) $-3 \alpha,-3 \beta$, $-3 \gamma$, which belong to HNF-3/forkhead family of transcription factors (Kaufmann and Knöchel 1996) and also Ets-like domain-containing protein (Ets) and NFATp (Janknecht 1993, Rao 1994, Fürstenau et al.1997, Fürstenau et al.1999). The third enhancer-like element, octameric CRE, resides between bases -291 to -298 and confers activation of glucagon gene transcription in response to a rise in the intracellular cAMP levels (Knepel et al.1990a) and by protein kinase A activation (Knepel et al.1990a, Miller et al.1993). The CRE-binding protein CREB belongs to the leucine zipper family of transcription factors. It has been shown to confer calcium and CAMP-dependent activation of the glucagon gene transcription (Meyer and Habener 1993). The $G 3$ element (-264 to -238 bp) comprises two domains: $A$ and $B$ which bind different nuclear proteins (Knepel et al.1990b). Transcription factors which bind to G3B domain were characterised as a heterodimer containing homeodomain proteins: prep1/pbx (Herzig et al. 2000). G3A domain contains a core sequence TTTYACRCCTSA which is also found in upstream element (UE) of the rat somatostatin gene, the enhancer 1 element (E1) of the rat insulin I gene and G1 element of rat glucagon gene (Knepel et al.1991).

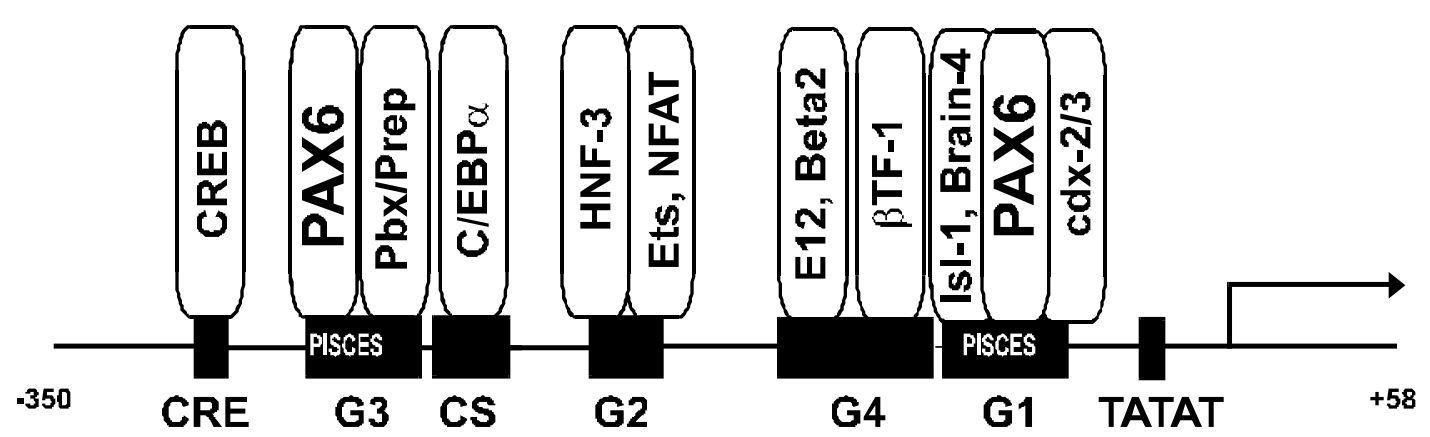

Fig. 2. -350 bp region of the rat glucagon gene with indicated regulatory DNA elements and their transcription factors. See the text below for further details. 
This sequence confers transcriptional activity in cell lines of A-cell phenotype and therefore was termed pancreatic islet cell-specific enhancer sequence, PISCES (Knepel et al.1991). Recently the paired box-containing transcription factor Pax6 has been identified as a G3A-binding protein (Sander et al.1997).

\subsection{Pax6.}

Pax6 is expressed in the central nervous system and the endocrine pancreas during development and in adult (Strachan and Read 1994), and has been shown to be crucial for development of these tissues (Sander et al.1997, Mansouri et al.1996). Pancreata of Pax6 homozygous mutant mice lack glucagon-producing cells, suggesting that Pax6 is essential for the differentiation of the A-cell (St-Onge et al.1997).

The Pax6 gene is expressed in at least two isoforms, only one of which binds the PISCES motif (Beimesche et al.1999). An alternatively spliced exon 5a results in the insertion of 14-amino acid peptide in the N-terminal part of the Pax6 paired domain (Fig. 3). The Pax6 paired domain binds PISCES very well, whereas the extended variant (Pax6-5a) does not (Beimesche et al. 1999).

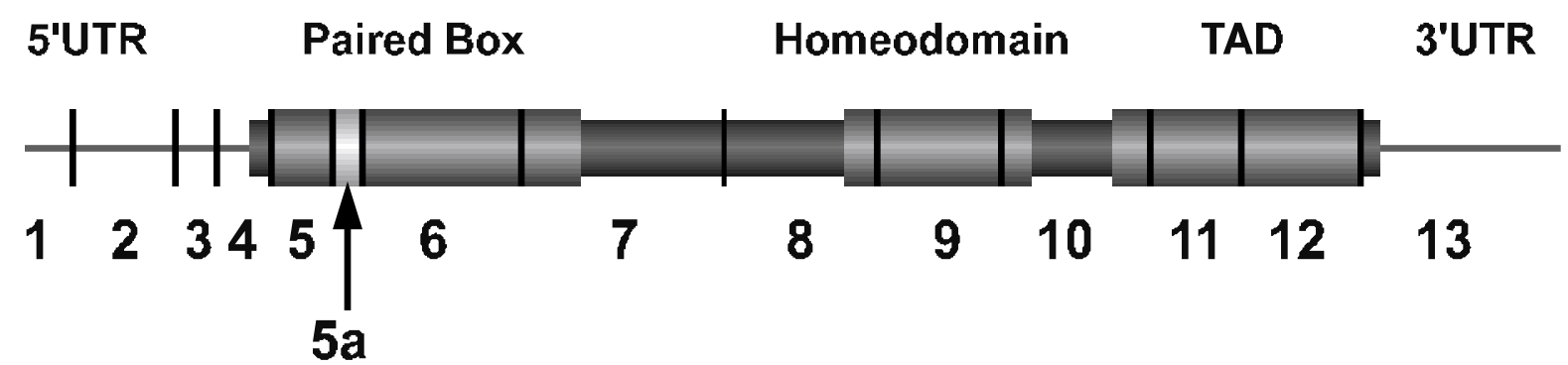

Fig. 3. Pax6 cDNA. Indicated are main functional domains (enlarged) and exon structure from human. UTR - untranslated region, TAD - transactivation domain. An arrow indicates the alternatively spliced exon $5 a$.

Recently it has been shown that the C-terminal transactivation domain of Pax6 can bind to the coactivator p300/CBP (Tang et al.1998, Hussain and Habener 1999), suggesting that recruitment of CBP may be important for the function of Pax6 at the glucagon promoter. 


\subsection{The aim of the study.}

The aim of the present work was to study the involvement of Pax6 in the regulation of glucagon gene transcription by insulin. This was approached mainly by performing transient transfection assays using glucagon-reporter fusion genes and the glucagonproducing pancreatic islet cell line InR1-G9. The GAL4/E1B system was applied as well. 


\section{MATERIALS AND METHODS}

\subsection{Chemicals}

Braun, Melsungen

Aqua ad injectabilia (Ampuwa)

Merck, Darmstadt

Calcium chloride-dihydrate

Natriumacetate-trihydrate

Pharmacia, Freiburg

DEAE-Dextran 6000

Deoxynucleotides (dATP, dCTP, dGTP, dTTP)

Serva, Heidelberg

Acrylamide

$\mathrm{N}, \mathrm{N}-$ Methylenebisacrylamide
Sigma, Munich

APS

BSA

Bromophenol Blue

DEPC

Ethidiumbromide

IPTG

Luciferin

Polyvinylalcohol

Glutathione

TEMED

Tween 20

Triton X-100

$X$-Gal

Xylene Cyanol FF

\subsection{Radiochemicals}

$\left(\alpha^{-32} \mathrm{P}\right)$-dCTP (activity $3000 \mathrm{Ci} / \mathrm{mmol}$ ) (ICN Biomedicals $\mathrm{GmbH}$, Eschwege) $\left(\gamma^{32} \mathrm{P}\right)$-dATP (activity $>6000 \mathrm{Ci} / \mathrm{mmol}$ ) (NEN Life Science Products, Köln)

\subsection{Antibiotics and protease inhibitors}

Ampicillin

Penicillin-Streptomycin solution

$(10,000 \mathrm{U} / \mathrm{ml}-10,000 \mu \mathrm{g} / \mathrm{ml})$

Aprotinin

Pepstatin

PMSF
(Boehringer, Mannheim)

(Boehringer, Mannheim)

(GIBCO-BRL , Karlsruhe)

(Sigma, Munich)

(Sigma, Munich)

(Boehringer, Mannheim) 


\subsection{Enzymes and kits}

Klenow fragment of DNA polymerase I

Lysozyme

Restriction endonucleases

RNase A

T4 DNA ligase

T4 DNA polynucleotidekinase

Taq DNA polymerase

Trypsin/EDTA

Bio-Rad protein assay

Gene $\quad A p^{\circledR} \quad$ Thermostable rTth

Reverse-Transcriptase RNA PCR Kit

High Pure ${ }^{\mathrm{TM}}$ PCR Purification Kit

Mermaid Kit

Original TA Cloning ${ }^{\circledR}$ Kit

OIAquick ${ }^{\text {TM }}$ Gel Extraction Kit

Thermo Sequenase Fluorescent

Labelled Primer Cycle Sequencing Kit
(Pharmacia, Munich)

(Sigma, Munich)

Pharmacia, Munich)

(MBI, St. Leon-Rot)

(Boehringer, Mannheim)

(MBI Fermentas, St. Leon-Rot)

(Boehringer, Mannheim)

(GIBCO-BRL , Karlsruhe)

(Bio-Rad, Munich)

(Perkin Elmer, Langen)

(Boehringer, Mannheim)

(Bio 101 Inc., USA)

(Invitrogen, NV Leek, Nederlands)

(Qiagen, Hilden)

Amersham (Braunschweig)

\subsection{Bacterial culture materials}

Select-Agar (GIBCO-BRL, Karlsruhe), Select-Peptone (GIBCO-BRL, Karlsruhe), Select-Yeast Extract (GIBCO-BRL , Karlsruhe), Petri dishes (10 cm) (Greiner, Frickenhausen).

\subsection{Eukayriotic cell culture materials}

DMEM and RPMI 1640 media, and FCS (Gibco-BRL, Karlsruhe).

Falcon dishes (Becton, Dickson, UK).

\subsection{Filters and separation columns}

Nitrocellulose membranes (Hybond-ECL) (Amersham, USA)

"Poly-Prep Chromatography Columns" (Bio-Rad, Munich) 


\subsection{Buffers and media}

Routinely used buffers and media were prepared according to "Molecular Cloning" laboratory manual (Sambrook et al. 1989) using bidestilated, deionised water.

\section{Buffers}

\section{LB Medium}

Select Peptone

$$
1 \% \quad(w / v)
$$

Select Yeast Extract

$\mathrm{NaCl}$

For the preparation of agar plates, agar $(1.5 \% \mathrm{w} / \mathrm{v})$ was added to LB medium, and if appropriate ampicillin $(50 \mu \mathrm{g} / \mathrm{ml})$, or chloramphenicol $(34 \mu \mathrm{g} / \mathrm{ml})$ added. The medium was autoclaved to sterilise.

\section{$10 \times$ MOPS}

MOPS

$\mathrm{NaAc}$

EDTA, pH 7.0

\section{$1 \times$ PBS}

$\mathrm{NaCl}$

$\mathrm{KCl}$

$\mathrm{Na}_{2} \mathrm{HPO}_{4}$

$\mathrm{KH}_{2} \mathrm{PO}_{4}$

$\mathrm{pH}$ adjusted to 7.4

\section{RNase A solution}

\section{RNase A}

Tris, pH 8.0

$\underline{6 \times \text { Stop mix }}$

$\begin{array}{ll}\text { Glycerine } & 30 \%(\mathrm{v} / \mathrm{v}) \\ \text { Bromophenol Blue } & 0.25 \%(\mathrm{w} / \mathrm{v}) \\ \text { Xylene Cyanol FF } & 0.25 \%(\mathrm{w} / \mathrm{v})\end{array}$

$200 \mathrm{mM}$

$50 \mathrm{mM}$

$10 \mathrm{mM}$

$140 \mathrm{mM}$

$2.5 \mathrm{mM}$

$8.1 \mathrm{mM}$

$1.5 \mathrm{mM}$
$0.1 \mathrm{mg} / \mathrm{ml}$

$5 \mathrm{mM}$

$0.25 \%(\mathrm{w} / \mathrm{v})$ 


\section{$5 \times \mathrm{TBE}$}

Tris, $\mathrm{pH} 8.0$

$450 \mathrm{mM}$

Boric Acid

$450 \mathrm{mM}$

EDTA, pH 8.0

$10 \mathrm{mM}$

TE

Tris, pH 8.0

$10 \mathrm{mM}$

EDTA, pH 8.0

$1 \mathrm{mM}$

Stock solutions

Ampicillin

$50 \mathrm{mg} / \mathrm{ml}$

Chloramphenicol

$34 \mathrm{mg} / \mathrm{ml}$

6X Loading buffer

Bromophenol blue

$30 \% \mathrm{w} / \mathrm{v}$

Glycerol

$50 \% \mathrm{v} / \mathrm{v}$

TE buffer

ad $100 \%$

Media for eukaryiotic cells culture

DMEM medium ( $1 \mathrm{~L}$ ): DMEM powder $13 \mathrm{~g}, \mathrm{NaHCO}_{3} 3.7 \mathrm{~g}$, volume adjusted to $1 \mathrm{~L}$ with distilled water and filter sterilised.

RPMI medium (1 L): RPMI 1640 medium powder, $\mathrm{NaHCO}_{3} 2 \mathrm{~g}$, volume adjusted to 1

$\mathrm{L}$ with distilled water and filter sterilised.

Medium for InR1G9 cell line

RPMI medium ad $500 \mathrm{ml}$

FCS $50 \mathrm{ml}$

Penicillin-Streptomycin Solution $\quad 5 \mathrm{ml}$

Medium for HepG2 cell line

DMEM medium ad $500 \mathrm{ml}$

FCS $50 \mathrm{ml}$

Penicillin-Streptomycin solution $\quad 5 \mathrm{ml}$ 
Medium for JEG cell line

$\begin{array}{ll}\text { DMEM medium } & \text { ad } 500 \mathrm{ml} \\ \text { FCS } & 50 \mathrm{ml} \\ \text { Penicillin-Streptomycin Mix } & 5 \mathrm{ml}\end{array}$

\subsection{Oligonucleotides}

All oligonucleotides are depicted in 5' to 3' orientation.

\section{PCR primers}

Gal4 motif in small letters. Restriction site in bold face.
1 (-350up)
CGTACTCGAGATGGCCAAATAGCACATCAAGG
2 (+58down)
GTAGATCTAGACAGGTGGAGCTCCTTTGG
3 (-149down)
CTGACCGCGGTACCGGGGTGAGACCTCAGAG
4 (-92up)
CTGACCGCGGATTATTTACAGATGAGAAATTTATATTG
5 (G3down)
CAGTCTAGACTTCAGCTCTCTGAAGTGAATTTG
6 (G3up)
CAGTCTAGAcggagtactgtcctccgTTGAAGGGTGTATTTCAAAC
7 (G1down)
CGAATTCTGGGGTTTTGTTCAAATGATTTCACTCGC
8 (G1up) CGAATTCcggagtactgtcctccgATTGTCAGCGTAATATCTGC
BamHI (up) GCCTTGGATCCATGCAGAACAGTCACAGC
Munl (down)
GTAGGCAATTGCTCGATCACATGCTCTCT

RT-PCR primers

exon2 (up)

ACGAAAGAGAGGATGCCTC

exon6 (down)

CCCAAGCAAAGATGGAAG

exon6 (up)

CATCTTTGCTTGGGAAATC

exon13 (down)

AACTTGGACGGGAACTGAC

Sequencing primers

5'-end fluorescently labelled with IRD800 (MWG-Biotech, Ebersberg)

M13reverse

CAGGAAACAGCTATGAC

T7Promoter

TAATACGACTCACTATAGGG

Luciferase gene CCATTTTACCAACAGTACCG

CMV promoter

CAGAGCTCGTTTAGTGAACC 


\section{EMSA oligonucleotide probes}

An oligonucleotide with the sequence of the rat glucagon promoter between bases 290 and -237 containing the G3 element (bold font), with the 5'-end GATC overhang (italics font) was used as a probe in EMSA: The PISCES element is double underlined:

GATCCTGAAGTAGTTIITCACGCCTGACTGAGATTGAAGGGTGTAGC

The second oligonucleotide used in this work contained the GAL4-binding motif and the 5'-end GATC overhang (italics font):

\section{GATCCGGAGTACTGTCCTCCG}

\subsection{Reporter gene plasmids}

All constructs were sequenced by enzymatic cycle sequencing to confirm the identity and the orientation of the inserts.

The construct -350(-150/-91)GluLuc, containing an internal deletion from -149 to 92, was prepared by PCR replacing the deleted bases by single Sacl site. Two PCR products generated with primer pairs 1/3 and 2/4 (2.8), were digested by Xhol/Sacll and Sacl//Bg/l/ respectively and ligated into Xhol/Bg/ll site of pXP2. In the constructs -350(mutG1)GluLuc, -350(mutG3)GluLuc, and -350(mutG1/G3)GluLuc the Pax6binding PISCES motifs within G1, G3 or G1 plus G3 were mutated into a GAL4 binding site. The constructs were generated by PCR from -350GluLuc. For 350(mutG1)GluLuc two PCR fragments were synthetised with the primer pairs 1/7 and 8/2 (2.9); after digest with Xhol/EcoRl and EcoRl/Bg/ll respectively, the fragments were ligated into the Xhol/Bglll sites of pXP2. For -350(mutG3)GluLuc two PCR fragments were generated with the primer pairs $1 / 5$ and 6/2 (2.9); after digest with $X \mathrm{Xol} / \mathrm{Xbal}$ and $\mathrm{Xbal} / \mathrm{Bg} / \mathrm{ll}$ respectively, the fragments were ligated into the $\mathrm{Xhol}$ Bg/ll sites of pXP2. Similarly for -350(mutG1/G3)GluLuc three PCR fragments were generated with the primer pairs 1/5, 6/7, and 8/2 (2.9); after digest with Xhol/Xbal, $X b a l / E c o R l$ and $E c o R I / B g / l$ respectively these fragments were ligated into the Xhol/Bglll sites of pXP2. The plasmid pCMV-GFPtpz was purchased from CanberraPackard, Dreieich, Germany. The plasmid pBP (Bluescript) was purchased from 
Stratagene, Germany. The constructs, which were used in this work and were not prepared, are summarised in Tab. 1. The 4xG3A(T81)Luc contains four copies of the oligonucleotides containing the A domain from the rat G3 element (bp -277 to -261) were cloned in front of the $-81 \mathrm{bp}$ of the minimal thymidine kinase promoter. In case of the $4 \times$ G2(-136)GluLuc construct four copies of the $\mathrm{G} 2$ oligonucleotides were cloned in front of the -136 glucagon promoter region.

Reporter gene construct

Reference

pT81Luc

Nordeen, 1988

-350GluLuc

Schwaninger et al., 1993

-136GluLuc

Grzeskowiak et al., 2000

5xGal4(E1B)Luc

Krüger et al., 1997

4xG2(T81)LuC

Grzeskowiak et al., 2000

4xG3A(T81)Luc

Wrege et al., 1995

pXP2

Nordeen, 1988

Tab. 1. Reporter gene constructs, which were used in this work and were not prepared.

\subsection{Expression plasmids}

All constructs were sequenced by enzymatic cycle sequencing to confirm the identity, the orientation or/and frame of the inserts.

An expression vector encoding GAL4-Pax6 fusion protein was prepared as follows: the BamHI-Kpnl fragment of the plasmid Pax-sc-35 (obtained from P. Gruss, MPI Göttingen, Germany), containing full length Pax6 cDNA, was cloned into the BamHIKpnl sites of Gal4-fusion expression vector - pSG424 (Sadowski et al., 1989); the HindllI-EcoRV fragment of this plasmid, containing the GAL4-Pax6 fusion protein, was cloned into the HindllI-EcoRV sites of the CMV-driven eukaryotic expression vector pBAT14 (obtained from M. German, San Francisco, CA). For preparation of an expression vector encoding the Pax6 paired domain ( $P$ Pax6-PD) the plasmid pBAT14m.Pax6 (obtained from M. German, San Francisco, CA) was digested with 
Bg/ll and HindlII, blunt ended by Klenow fill-in reaction, and fragment containing only paired box (amino acids 1-246) was religated. All constructs were sequenced by enzymatic cycle sequencing to confirm the identity and the orientation of the inserts.Plasmid encoding GST-fused full length Pax6, pGST-Pax6(FL), for bacterial expression was cloned as follows: PCR product, using as a template Pax-sc-35 (obtained from P. Gruss, Göttingen, Germany) and primer pair BamHI(up)/Munl(down) (2.9), was digested by BamH/Munl and ligated into $B a m \mathrm{HI} / E c o R$ l site of pGEX-2T (Amersham-Pharmacia). The expression constructs, which were used in this work but were not prepared are listed in the Tab. 2.

GAL-CBP8 (full length: amino acids 1-2141)

GAL4CBP[1-451]

GAL4CBP[1061-1891]

GAL4CBP[1892-2441]

GAL4CBP[1880-2441]

GAL4CBP[2040-2441]

GAL4CBP[2040-2170]

GAL4CBP[2306-2441]

GAL4CBP[2171-2441]

GAL4CBP[1678-2441]

GAL4CBP[1678-2441] ${ }^{\Delta 2040-2306}$

GAL4CBP[1678-2441] ${ }^{\Delta 2040-2170}$

GAL4-VP16

GAL4-TADwt

GAL4-TADm3

myrPKB
Chrivia et al., 1993

Kurokawa et al., 1998

Kurokawa et al., 1998

Kurokawa et al., 1998

research group Prof. W. Knepel

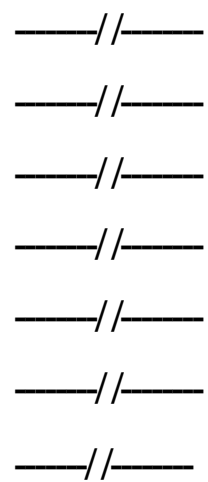

Roberts et al., 1994

Mikkola et al. 1999

Mikkola et al. 1999

Tab. 2. Expression constructs, which were used in this work and were not prepared. GAL4-CBP constructs were generated by fusing the GAL4 DNA-binding domain (amino acids 1-147) to part of CBP (amino acids indicated in the square brackets). Internal deletion in the last two CBP constructs is indicated in upper case. 


\subsection{Bacterial strains}

E. coli strain HB101 $\left(\mathrm{amp}^{\mathrm{R}}\right)$ was used for for standard cloning procedures and plasmid amplification. E. coli strain BL21(DE3)pLys $\left(\mathrm{amp}^{\mathrm{R}}, \mathrm{CA}^{\mathrm{R}}\right.$ ) (Novagen, USA) was used for bacterial GST-PAX6 expression. This strain carries pLys plasmid with IPTG-inducible T-7 lysozymogen gene. E. coli strain TOP10F' (amp ${ }^{\mathrm{R}}, \mathrm{KA}^{\mathrm{R}}$, Lacl) (Invitrogen, NV, Leek) was used for blue/white screening of RT-PCR product cloning.

\subsection{Eukaryotic cell lines}

The following cell lines were used: glucagon-producing Golden Hamster pancreatic tumor cell line, InR1G9 (A-cell phenotype) (Takaki et al. 1986); human choriocarcinoma cell line, JEG-3 (Kohler and Bridson 1971).

\subsection{Tissue collection}

Brain, cerebellum, eye and whole pancreas or pancreatic islets were collected from wild type mice strain Bar Harbor CF1. Tissues were immediately frozen in liquid nitrogen and stored at $-80^{\circ} \mathrm{C}$.

\subsection{Antisera and antibodies}

Pax6 (C-20) goat polyclonal IgG (Santa Cruz Biotechnology, Heidelberg)

Anti-goat IgG-HRP

(Santa Cruz Biotechnology, Heidelberg)

Anti-Pax6 serum

(Turque et al. 1994)

\subsection{Molecular weight standards}

DNA standards

$\lambda$-DNA digested with HindIII/EcoRI (Pharmacia, Freiburg) and "20 bp ladder" (Invitrogen, NV Leek).

\section{Protein Standards}

For SDS PAGE analysis pre-stained protein weight standard (Sigma, Munich) with the size range $205,112,87,69,56,38,5,33.5 \mathrm{kD}$ were used. 


\subsection{Standard methods for handling RNA and DNA}

\section{Sterilisation}

Glassware and solutions which required inactivation of microorganisms, proteases or nucleases were autoclaved under following conditions: $20 \mathrm{~min}, 120^{\circ} \mathrm{C}, 10^{5} \mathrm{~Pa}$. Heatlabile substances (i.e. antibiotics, SDS, PEG) were prepared with sterile water or were sterilized by filtration (Minisart-Filters, Sartorius, Göttingen).

\section{Phenol-chloroform extraction}

Protein impurities were removed by vigorous shaking of DNA solution with equal volume of phenol/chloroform/isoamyl alcohol mixture (25:24:1). Emulsion was then centrifuged (1 min, RT, $14000 \mathrm{rpm}$ ), and upper aqueous phase was collected for DNA precipitation.

\section{DNA/RNA precipitation}

DNA was precipitated by addition of $\mathrm{NaAc}$ (final conc. $0.3 \mathrm{M}$ ) and one volume of isopropanol. The mixture was then vortexed and centrifuged $\left(5 \mathrm{~min}, 4^{\circ} \mathrm{C}, 14000\right.$ rpm). The pellet was washed with $70 \%$ ethanol and centrifuged (5 min, RT, 14000 rpm). After washing the supernatant was aspirated and the pellet was vacuum dried. Dried DNA was redissolved in sterile water or TE buffer. RNA was precipitated in a similar way. After addition of $\mathrm{NaAc}$ and isopropanol the mixture was freezed for 30 $\min$ at $-80^{\circ} \mathrm{C}$. After thawing the mixture was centrifuged $\left(15 \mathrm{~min}, 4^{\circ} \mathrm{C}, 14000 \mathrm{rpm}\right)$ and than washed twice with $80 \%$ ethanol as above. After washing the supernatant was aspirated and the pellet was vacuum dried. Dry pellet was redissolved in RNase free water or TE buffer.

\section{Dialysis}

DNA solutions were put into a dialysis tube (GIBCO/BRL, Karlsruhe), which was then closed with clips and placed in 1L TE buffer in a container with stirring. Dialysis was done twice for $12-16 \mathrm{hrs}$ at $4^{\circ} \mathrm{C}$. 


\section{Annealing of DNA oligonucleotides}

Double-stranded EMSA probes were prepared as follows: in $50 \mu \mathrm{l}$ volume two singlestranded oligonucleotides (100 pmol each) and $\mathrm{NaCl}$ (final conc. $10 \mathrm{mM}$ ) were mixed. Using TRIO-Thermoblock (BIOMETRA) the mixture was denaturated for 1 min at $95^{\circ} \mathrm{C}$ and then cooled down slowly where each following temperature step lasted 5 min: $85^{\circ} \mathrm{C}, 75^{\circ} \mathrm{C}, 65^{\circ} \mathrm{C}, 55^{\circ} \mathrm{C}, 45^{\circ} \mathrm{C}, 35^{\circ} \mathrm{C}, 20^{\circ} \mathrm{C}$.

\section{Radioactive labeling of DNA oligonucleotides by Klenow "fill-in" reaction}

Double-stranded DNA probes possessing 5'-GATC overhangs were labeled using ${ }^{32} \mathrm{P}$ - dCTP and Klenow fragment of DNA Polymerase I. The "fill-in" reaction was set up on ice in total volume $20 \mu \mathrm{l}$ :

$\begin{array}{ll}\text { double-stranded oligonucleotide, } 2 \mathrm{pmol} / \mu \mathrm{l} & 1 \mu \mathrm{l} \\ \text { dNTPs (without dCTP), } 1 \mathrm{mM} & 1 \mu \mathrm{l} \\ \left.10 \times \text { Klenow Buffer (Tris } 0.5 \mathrm{M}, \mathrm{MgCl}_{2} 0.1 \mathrm{M}\right) & 2 \mu \mathrm{l} \\ \text { Klenow Fragment, } 1 \mathrm{U} / \mu \mathrm{l} & 2 \mu \mathrm{l} \\ \alpha^{-32} \mathrm{P} \text {-dCTP, } 10 \mu \mathrm{Ci} / \mu \mathrm{l} & 2 \mu \mathrm{l} \\ \text { water } & 12 \mu \mathrm{l}\end{array}$

The reaction mixture was incubated for $1 \mathrm{hr}$ at $37^{\circ} \mathrm{C}$. Unincorporated nucleotides and salts were removed using Nucleotide Removal Kit (Qiagen, Hilden). For $20 \mu \mathrm{l}$ reaction, $200 \mu \mathrm{l}$ of binding buffer was added and after $1 \mathrm{~min}$ incubation the mixture was applied to QIA-quick column and centrifuged (2 min, RT, $6000 \mathrm{rpm}$ ). The flowthrough was discarded and $500 \mu \mathrm{l}$ of Washing Buffer was applied to the column followed by centrifugation $2 \mathrm{~min}, \mathrm{RT}, 6000 \mathrm{rpm}$ (flow through discarded). The washing step was repeated and then column was again centrifuged without addition of any buffer to dry (2 min, RT, $6000 \mathrm{rpm}$ ). Probe was eluted with $20 \mu \mathrm{l}$ of Elution Buffer and fraction was collected by centrifugaton: $2 \mathrm{~min}, \mathrm{RT}, 6000 \mathrm{rpm}$. $1 \mu \mathrm{l}$ of the eluate was mixed with $4 \mathrm{ml}$ of Scintillation Liquid (Quicksafe A, Zinser Analytic, Frankfurt) and measurement of the radioactivity incorporation was done using scintillation counter (Beckman LS 1801, Munich). The probe was then diluted to final activity of $20,000 \mathrm{cpm} / \mu \mathrm{l}$. 


\section{Estimation of nucleic acid concentration}

The concentration of nucleic acids was estimated by measuring absorbtion at $260 \mathrm{~nm}$ using Shimadzu UV 160-Spectralphotometer (Duisburg). Concentration was calculated using the $\mathrm{OD}_{260}=1$ for the following amounts of nucleic acids

$\begin{array}{lll}\text { Double-stranded DNA } & 50 & \mu \mathrm{g} / \mathrm{ml} \\ \text { Single-stranded DNA } & 20 & \mu \mathrm{g} / \mathrm{ml} \\ \text { RNA } & 40 & \mu \mathrm{g} / \mathrm{ml}\end{array}$

In addition to $\mathrm{OD}_{260}$ also the absorbtion at $280 \mathrm{~nm}$ was measured indicating protein concentration. DNA or RNA preparations which had ratio of $O D_{260} / \mathrm{OD}_{280}$ in the range of 1.8-2.0 were regarded as pure and protein-free (Sambrook et al. 1989).

\subsection{Gel electrophoresis}

\section{Agarose gel electrophoresis}

Analysis of RT-PCR products, restriction enzyme digest, minipreparations of plasmid DNA or enzymatic modifications of DNA was done with the use of agarose gel electrophoresis. Agarose gel $(0.8 \%-2.5 \%)$ was prepared in TBE buffer by heating to ca. $60^{\circ} \mathrm{C}$, and ethidium bromide $(0.5 \mu \mathrm{g} / \mathrm{ml})$ was added before pouring the gel into the tray. Before loading samples were mixed with $6 x$ loading buffer. Electrophoresis was run in a horizontal apparatus (Bio Rad, Munich) under constant current and voltage of 5-10 V per $1 \mathrm{~cm}$ of gel length. After electrophoresis DNA fragments in the agarose gel containing ethidium bromide were visualised using UV (254 or $366 \mathrm{~nm}$ ) transiluminator (Vetter $\mathrm{GmbH}$, Wiesloch) and photographed for archivisation and analysed using a camera and software set (E.A.S.Y., Wiesloch).

\section{Purification of DNA fragments from agarose gel}

DNA fragments were purified after agarose gel electrophoresis using High Pure ${ }^{\mathrm{TM}}$ PCR Purification Kit (Boeringer, Mannheim). This procedure allows DNA fragments separated electrophoretically to be purified from other DNA fragments, salts or unincorporated nucleotides prior to cloning or other procedures. 
After electrophoresis the DNA fragment was excised from the agarose gel with sterile scalpel (band was visualised by UV transiluminator), transferred to sterile Etube and mixed with Binding Buffer ( $300 \mu \mathrm{l}$ per $1 \mathrm{mg}$ of gel). Samples were incubated for $15 \mathrm{~min}$ at $56^{\circ} \mathrm{C}$ to melt agarose and then vortexed shortly. For fragments shorter than $300 \mathrm{bp}$, isopropanol was added $(150 \mu \mathrm{l} / 1 \mathrm{mg}$ of gel). Samples were then transferred into the High Pure SpinColumns and centrifuged for $30 \mathrm{sec} ., 14000 \mathrm{rpm}$, RT. Flow through was discarded and $500 \mu \mathrm{l}$ of Washing Buffer was applied to the columns followed by centrifugation for $30 \mathrm{sec}$., $14000 \mathrm{rpm}$, RT. Again the flow through was discarded and for the second wash $200 \mu \mathrm{l}$ of Washing Buffer was applied and then samples were centrifuged as before. To elute the DNA fragment columns were placed in fresh, sterile E-tubes and 30-100 $\mu \mathrm{l}$ of water or Elution Buffer was applied. Elution was done by centrifugation of samples for $30 \mathrm{sec}$., $14000 \mathrm{rpm}$, RT.

Washing Buffer ( $\mathrm{pH} 7.5)$

$\mathrm{NaCl}$ $20 \mathrm{mM}$

Tris- $\mathrm{HCl}$ $10 \mathrm{mM}$

Et-OH $30 \%$

Binding Buffer ( $\mathrm{pH} 6.6)$

Guanidin-thiocyanate $3 \mathrm{M}$

Tris- $\mathrm{HCl}$ $10 \mathrm{mM}$

Ethanol $5 \%(\mathrm{v} / \mathrm{v})$

Elution Buffer ( $\mathrm{pH} 8.5)$

Tris- $\mathrm{HCl}$ $10 \mathrm{mM}$

EDTA $1 \mathrm{mM}$

\section{Autoradiography}

Radioactively labelled DNA fragments from EMSA were visualised by autoradiography. After electrophoresis, the gel was dried under vacuum using gel dyer (G200, Fröbel, Blaufelden) and placed over Phosphor-Imager screen and exposed for 16 hrs, RT. Screens were scanned using Phosphor-Imager reader (Fujix 
BAS 1500, Raytest, Straubenhardt) and data subject to software analysis (TINA Data Reader $^{\mathrm{TM}}$ ). Alternatively EMSA gels were subject to autoradiography with use of Roentgen films (Hyperfilm MP, Amersham, Braunschweg). Exposition was done in Roentgen cassettes (Kodak X-Omatic) in $-80^{\circ} \mathrm{C}$ for $2-4$ days. Development of the film was done by incubation ca. $15 \mathrm{sec}$. in developer solution (LX 24, Kodak) then short wash in water and incubation in fixer solution ca. $15 \mathrm{sec}$. (AL 4, Kodak). After final wash in water film was dried.

\subsection{RT-PCR}

RT-PCR combines reverse transcription of RNA to cDNA performed by reverse transcriptase followed by PCR amplification of CDNA by DNA Polymerase. This extremely sensitive technique allows to detect or/and clone, in form of cDNA, even very rare mRNA molecules. In this work so called single-tube RT-PCR was employed, using Gene Amp ${ }^{\circledR}$ Thermostable rTth Reverse Transcriptase RNA PCR Kit (Perkin Elmer, Langen), to clone cDNA of PAX6 transcriptional factor from different tissues. Here rTth-DNA-Polymerase was used which in the presence of Manganium ions $\left(\mathrm{MnCl}_{2}\right)$ performs reverse transcription reaction primed by a mRNA sequence-specific primer. After cDNA synthesis the reaction conditions are changed by addition of $\mathrm{Mn}^{+2}$ chelator and $\mathrm{MgCl}_{2}$. In presence of $\mathrm{Mg}^{+2}$ rTth-DNA-Polymerase performs DNA synthesis and the PCR is started. General algorythm of the PCR was as follows: denaturation of template, annealing of primers, elongation of primers with thermostable DNA-Polymerase. This cycle was repeated 25 to 30 times allowing to amplify exponentially DNA fragments of interest (derived from PAX6 mRNA). After all cycles were performed, a final elongation step was included to assure that full lenght DNA fragments are synthesised. To avoid inefficient reverse transcription reaction due to secondary mRNA structures, initial denaturation step $\left(5 \mathrm{~min}, 70{ }^{\circ} \mathrm{C}\right)$ was included before addition of $r$ Tth-DNA-Polymerase (RT MixA). Pipetting, pipette tips and solutions were kept RNase/DNase free as were the tubes used (Thin-Walled PCR Tubes, $500 \mu$ l, Boerhinger, Mannheim).

Typically RT reaction was done as follows: RT Mix A was incubated 5 min at $70^{\circ} \mathrm{C}$ (Biometra TRIO-Thermoblock with heated cover) and then $5.6 \mu \mathrm{l}$ of RT Mix B was added. RT reaction was run for $15 \mathrm{~min}$ at $60^{\circ} \mathrm{C}$ in Biometra TRIO-Thermoblock with heated cover. In parallel negative control reaction without RT step was done by 
incubating samples for the same time on ice. After RT reaction step samples were cooled on ice (5 min) and $80 \mu \mathrm{l}$ of PCR Mix was added to each. PCR was run according to profiles in Tab. 3.

Primer Pair Denaturation PCR cycles profile Cycles Elongation

2up/6down $\quad 94^{\circ} \mathrm{C} / 4 \min \quad 95^{\circ} \mathrm{C} / 30$ sec., $58^{\circ} \mathrm{C} / 1 \mathrm{~min}, 72^{\circ} \mathrm{C} / 3 \min \quad 35 \quad 72^{\circ} \mathrm{C} / 5 \mathrm{~min}$

6up/13down $\quad 94^{\circ} \mathrm{C} / 5 \min \quad 95^{\circ} \mathrm{C} / 30$ sec., $59^{\circ} \mathrm{C} / 1 \mathrm{~min}, 72^{\circ} \mathrm{C} / 2 \min \quad 40 \quad 72^{\circ} \mathrm{C} / 5 \mathrm{~min}$

Tab. 3. PCR temperature profiles. Summary of primer pairs and PCR profiles used to amplify fragments of PAX6 cDNA covering the whole protein coding sequence. Two regions were amplified: one containing exons 2-6, and second exons 6-13 with overlapping region in exon 6."Primer Pair" - see 2.9.1 for sequences. "Denaturation" - temperature and time of initial DNA denaturation before starting main PCR cycles. "Cycles" - number of cycles in PCR protocol. "Elongation" - temperature and time of final elongation step after all PCR cycles.

$\underline{\mathrm{RT} \operatorname{Mix} \mathrm{A}}$

$10 \times$ RT Buffer

(Tris- $\mathrm{HCl}(\mathrm{pH}$ 8.3) 100 mM, KCl 900 mM)

"Down" Antisense Primer $(60 \mu \mathrm{M})$

total RNA

Ampuwa ad

$\underline{\text { RT Mix B }}$

$\mathrm{MnCl} 2(10 \mathrm{mM})$

dNTPs (each $10 \mathrm{mM}$ )

rTth-DNA-Polymerase $(2.5 \mathrm{U} / \mu \mathrm{l})$

PCR Mix

10x Chelating Buffer

$\mathrm{MgCl}_{2}$ (25 mM)

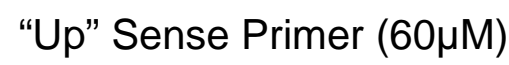

Ampuwa ad $\underline{\text { final conc. }}$

$\begin{array}{ll}2 \mu \mathrm{l} & 1 \mathrm{x} \\ 0.25 \mu \mathrm{l} & 0.75 \mu \mathrm{M} \\ \mathrm{x} \mu \mathrm{l} & 200 \mathrm{ng}\end{array}$

$14.4 \mu \mathrm{l}$

final conc.

$2 \mu \mathrm{l} \quad 1 \mathrm{mM}$

$1.6 \mu \mathrm{l} \quad$ each $200 \mu \mathrm{M}$

$2 \mu \mathrm{l} \quad 5 \mathrm{U} / 20 \mu \mathrm{l}$

final conc.

$8 \mu \mathrm{l} \quad 0.8 \mathrm{x}$

$4 \mu \mathrm{l} \quad 1 \mathrm{mM}$

$0.25 \mu \mathrm{l} \quad 0.15 \mu \mathrm{M}$

$80 \mu \mathrm{l}$ 
After the RT-PCR reaction, the products $(20-50 \mu \mathrm{l})$ were analysed by agarose gel electrophoresis (2.18). Specific product(s) were excised from gel and DNA was purified (2.18) for cloning into pCR2.1 T vector (Invitrogen, NV Leek).

\subsection{Enzymatic modification of DNA}

\section{"Addition of single A"}

RT-PCR products after purification from agarose gel were subject to cloning using "T/A" system: Taq DNA polymerase catalyses template-independent single A nucleotide addition to RT-PCR product ( $r$ Tth-DNA-Polymerase does not poses this activity). This single A "overhang" anneals with single T of linearised vector (pCR2.1 $T$ ) and facilitates cloning (igation is performed by Topo Isomerase bound to vector termini). Reaction was performed in total volume of $15 \mu \mathrm{l}$ :

"Addition of single A" Reaction

purified from gel RT-PCR product

$11.5 \mu \mathrm{l}$

10x PCR Buffer (Perkin Elmer)

$1.5 \mu \mathrm{l}$

Taq DNA Polymerase $(4 \mathrm{U} / \mu \mathrm{l})$

$0.5 \mu l$

dATP (10 mM)

$1.5 \mu \mathrm{l}$ (final conc. $1 \mathrm{mM}$ )

Reaction was incubated for $30 \mathrm{~min}$ at $72^{\circ} \mathrm{C}$ and $4 \mu \mathrm{l}$ were directly used for T/A TOPO cloning (see below).

\section{Endonuclease restriction}

Usually restriction digest was performed for $3-10$ hrs at $37^{\circ} \mathrm{C}$ using buffers and enzymes commercially available (MBI, Pharmacia) in total volume of 20-50 $\mu$ l. 1-2 U of restrictase was used per $1 \mu \mathrm{g}$ of DNA. The volume of restriction enzymes in the reaction was not greater than $10 \%$ of the total volume. 


\section{Ligation of DNA fragments}

Ligation of double-stranded DNA fragments (after restrictase digest) was performed with T4-DNA-Ligase. This enzyme performs ATP-dependent phospho-di-ester bond catalysis between 3'-hydroxyl and 5'-phosphate ends ("sticky" or "blunt"). DNA fragments were added in molar ratio vector to insert of 1:5-50 respectively. Ligation reaction was usually incubated for $16-20 \mathrm{hrs}$ at $10-16^{\circ} \mathrm{C}$. In $20 \mu \mathrm{l}$ of total volume were mixed:

T4-DNA-Ligase ligation

10x Buffer (MBI Fermentas) $2 \mu \mathrm{l}$

ATP $(2 \mathrm{mM}) \quad 0.5 \mu \mathrm{l}$

DNA fragments $\quad x \mu \mathrm{l}$

T4-DNA-Ligase $(1 \mathrm{U} / \mu \mathrm{l}) \quad 4 \mu \mathrm{l}$

water $\quad$ ad $20 \mu \mathrm{l}$

In case of T/A TOPO cloning system (Invitrogen, NV Leek) reaction was incubated in RT for 5 min (according to manual) and contained: $4 \mu \mathrm{l}$ of RT-PCR reaction and $1 \mu \mathrm{l}$ of pCR2.1 TOPO T-Vector (Invitrogen). Ligation reaction was directly used to transform bacteria.

\subsection{Standard methods of molecular cloning}

\section{Preparation of competent E.coli bacteria}

Competent bacteria are produced by modification of cell wall which facilitates DNA uptake. $100 \mathrm{ml}$ of LB medium was inoculated with single colony of E.coli strain $\mathrm{HB} 101$ (from stock plate) and culture was grown at $37^{\circ} \mathrm{C}, 200 \mathrm{rpm}$ till $\mathrm{OD}_{600}=0.6$. Bacteria were centrifuged $\left(10 \mathrm{~min}, 4^{\circ} \mathrm{C}, 3000 \mathrm{rpm}\right)$ and the pellet was resuspended in $50 \mathrm{ml}$ of sterile $50 \mathrm{mM} \mathrm{CaCl}$ solution $\left(4^{\circ} \mathrm{C}\right)$ and incubated on ice for $30 \mathrm{~min}$. The suspension of bacteria were centrifuged $\left(10 \mathrm{~min}, 4^{\circ} \mathrm{C}, 3000 \mathrm{rpm}\right)$ and the pellet was resuspended in $10 \mathrm{ml}$ of sterile $50 \mathrm{mM} \mathrm{CaCl} 2\left(4^{\circ} \mathrm{C}\right)$ with $15 \%$ glycerol. The mixture 
was dispensed into aliquots of $100 \mu \mathrm{l}$ and stored at $-80^{\circ} \mathrm{C}$. Competent TOP $10 \mathrm{~F}^{\prime}$ and BL21(DE3)pLys bacteria were purchased from Invitrogen, NV Leek.

\section{Transformation of competent bacteria}

Transformation of TOP10F' bacteria was done by gentle mixing of one aliquot (50 $\mu$ l) with $2 \mu \mathrm{l}$ of $0.5 \mathrm{M}$ B-ME and 2-3 $\mu \mathrm{l}$ of ligation reaction (RT-PCR products cloning with T/A TOPO system). After incubation for $30 \mathrm{~min}$ on ice bacteria were heated for 45 sec. at $42^{\circ} \mathrm{C}$, cooled for 3 min on ice and $300-\mu$ l of LB medium was added. Bacteria were incubated at $37^{\circ} \mathrm{C}, 200 \mathrm{rpm}, 1 \mathrm{hr}$ to allow antibiotic resistance expression and were plated out on LB-agar plates containing Amp 50 $\mu \mathrm{g} / \mathrm{ml}$, IPTG $1 \mathrm{mM}$ and X-Gal $40 \mathrm{mg} / \mathrm{ml}$ to allow "Blue-White" screening. Transformation of HB101 - used for standard cloning procedures - was done in a similar way. LB-agar plates did not contain IPTG and X-Gal. In case of BL21(DE3)pLys, $50 \mu$ aliquot was mixed with $2 \mu \mathrm{l}$ of $0.5 \mathrm{M}$ B-ME and 5-10 $\mathrm{ng}$ of construct DNA (GST-PAX6 fusion protein construct) and incubated on ice $30 \mathrm{~min}$. Bacteria were heated for exactly $30 \mathrm{sec}$. at $42^{\circ} \mathrm{C}$ and quickly cooled on ice ( $3 \mathrm{~min}$ ). Then $250 \mu \mathrm{l}$ of prewarmed SOC medium was added and bacteria were incubated in shaking incubator at $37^{\circ} \mathrm{C}, 225 \mathrm{rpm}$ for $1 \mathrm{~h}$ The whole transformation mixture was then used to inoculate $50-100 \mathrm{ml}$ of LB medium containing $100 \mu \mathrm{g} / \mathrm{ml}$ amp. $34 \mu \mathrm{g} / \mathrm{ml}$ of CA was added in the pilot culture for induction study or maxi scale culture for fusion protein isolation.

\section{Mini preparation of plasmid DNA}

A modified alkaline lysis method was used (Le-Gouill et al. 1994) to purify plasmid DNA. A single colony was inoculated into $5 \mathrm{ml}$ of LB amp medium and grown for 10$16 \mathrm{hrs}$ at $37^{\circ} \mathrm{C}, 225 \mathrm{rpm}$. Then bacterial culture was subject to the following protocol:

1. $1.5 \mathrm{ml}$ of culture was centrifuged of $\left(4^{\circ} \mathrm{C}, 6000 \mathrm{rpm}, 5 \mathrm{~min}\right)$, Eppendorf $5415 \mathrm{C}$.

2. The pellet was resuspended in $100 \mu \mathrm{l}$ of SOLUTION I.

3. $200 \mu \mathrm{l}$ of SOLUTION II was added (the tube was carefully inverted to mix) and $200 \mu \mathrm{l}$ of chloroform was added.

4. After 1 min of lysis $150 \mu \mathrm{l}$ of ice cold SOLUTION III was added and the mixture was vortexed for 2 seconds.

5. The mixture was centrifuged (RT, $14000 \mathrm{rpm}, 2 \mathrm{~min}$ ). 
6. The upper phase was taken (about $360 \mu \mathrm{l}$ ) and was precipitated with 1 vol. of $100 \%$ isopropanol.

7. The mixture was centrifuged $\left(4^{\circ} \mathrm{C}, 14000 \mathrm{rpm}, 5 \mathrm{~min}\right)$ and after this the supernatant was discarded.

8. The pellet was washed twice with $80 \% \mathrm{Et}-\mathrm{OH}$ and then dried under vacuum.

9. Dry pellet was redissolved in $20 \mu \mathrm{l}$ of RNAse I solution ( $1 \mu \mathrm{g}$ in $1 \mathrm{ml}$ of TE buffer) and incubated at $37^{\circ} \mathrm{C}$ for $1 \mathrm{hr}$ (RNA digestion).

10. Plasmid DNA was stored at $4^{\circ} \mathrm{C}$.

Solution I: $50 \mathrm{mM}$ glucose, $10 \mathrm{mM}$ EDTA, $25 \mathrm{mM}$ Tris-HCl, pH 8.0

Solution II: $0.2 \mathrm{~N} \mathrm{NaOH}, 1 \%$ SDS

Solution III: $29.4 \mathrm{~g} \mathrm{KAc}, 5 \mathrm{ml} \mathrm{HCOOH}$ and water to $100 \mathrm{ml}$

\section{"Maxi" preparation of plasmid DNA}

Large amounts of plasmid DNA (1-2 mg) were produced using preparative ultracentrifugation of bacterial lysate in a $\mathrm{CsCl}$ gradient. The protocol was as follows:

1. $15 \mathrm{ml}$ of LB+amp medium (final amp concentration $50 \mathrm{ng} / \mathrm{ml}$ ) was inoculated with a single colony.

2. The culture was grown overnight in a rotary shaker $\left(225 \mathrm{rpm}, 37^{\circ} \mathrm{C}\right)$.

3. 1 liter of a LB+amp medium was inoculated with $10 \mathrm{ml}$ of the overnight culture (rest of the overnight culkture was kept for reference).

4. The 1 liter culture was grown at $37^{\circ} \mathrm{C}$ until the $O D_{600}=0.8-1.0$ and then $C A$ was added to final concentration of $200 \mathrm{mg} / \mathrm{L}$. The culturte was further incubated in rotary shaker $\left(225 \mathrm{rpm}, 37^{\circ} \mathrm{C}\right)$ for additional $10-12 \mathrm{~h}$.

5. The 1 liter culture was centrifuged at $10000 \mathrm{rpm}$ (Beckman JA-14 Rotor) for 15 $\min$ at $4^{\circ} \mathrm{C}$.

6. The pellet was resuspended in $45 \mathrm{ml}$ ice-cold STE ( $25 \%$ saccharose, $1 \mathrm{mM}$ EDTA, $50 \mathrm{mM}$ TRIS pH 8.0) and $3 \mathrm{ml}$ of lysozyme $(60 \mathrm{mg} / \mathrm{ml} \mathrm{STE})$ was added.

7. After ncubation for $20 \mathrm{~min}$ on ice, $3.6 \mathrm{ml}$ of $0.5 \mathrm{M}$ EDTA was added and the mixture was incubated for $5 \mathrm{~min}$ on ice. Then $28.8 \mathrm{ml}$ of Triton-mix was added (0.1\% Triton X-100, $50 \mathrm{mM}$ Tris pH 8.0, $60 \mathrm{mM}$ EDTA). 
8. The mixture was incubated $30 \mathrm{~min}$ on ice (shaking every $5 \mathrm{~min}$ ).

9. The mixture was centrifugated for $1 \mathrm{hr}$, at $16000 \mathrm{rpm}$ (Beckman JA-20 Rotor) at $4^{\circ} \mathrm{C}$.

10. To the supernatant $40 \mathrm{ml}$ of $30 \% \mathrm{PEG}$ was added (30\%PEG $6000,1.5 \mathrm{M} \mathrm{NaCl}$ ), and the mixture was incubated for $1 \mathrm{~h}$ on ice.

11. The mixture was centrifugated for $10 \mathrm{~min}, 10000 \mathrm{rpm}$ (Beckman JA-14 Rotor) at $4^{\circ} \mathrm{C}$ and the supernatant was discarded.

12. The pellet was resuspended in $10 \mathrm{ml}$ of TNE buffer $(10 \mathrm{mM}$ Tris pH 8.0, $10 \mathrm{mM}$ $\mathrm{NaCl}, 1 \mathrm{mM}$ EDTA) and $10.9 \mathrm{~g}$ of $\mathrm{CsCl}$ plus $150 \mu \mathrm{l}$ of ethidiumbromide $(10 \mathrm{mg} / \mathrm{ml})$ was added.

13. The solution was pipetted into an ultracentrifuge tube and weighted. The difference between the tubes were not more than $0.05 \mathrm{~g}$.

14. The tubes were centrifuged (20 hrs, $60000 \mathrm{rpm}, 20^{\circ} \mathrm{C}$ ) (Beckman Ultracentrifuge L5-65, 70 Ti-Rotor).

15. The band containing plasmid DNA was recovered with syringe and niddle.

16. The Et-Br from the DNA solution was extracted several times with equal volumes of isoamyalcohol untill the solution was colorless.

17. The clear solution was put into dialysis tubings and dialysed twice at $4^{\circ} \mathrm{C}$ against TE (10 mM Tris pH 8.0, 1 mM EDTA pH 8.0) to remove CsCl.

18. The concentration and purity of the plasmid DNA was estimated spectrophotometrically $\left(\mathrm{OD}_{260}, \mathrm{OD}_{280}\right)$.

\subsection{DNA sequencing}

\section{Sequencing reaction}

Sequencing was done using Thermo Sequenase Fluorescent Labelled Primer Cycle Sequencing Kit (Amersham-Pharmacia, Braunschweg). This kit combines conventional dideoxy sequencing reactions (Sanger et al. 1977) with thermal cycling conditions to generate high quality sequences from very small amounts of template DNA. The use of thermostable Taq DNA polymerase makes it possible to repeatedly cycle the template through alternating periods of heat denaturation, annealing and polymerization at elevated temperatures. Under these conditions, the purity and quantity of starting template are less critical, with single colonies or plaques often 
providing sufficient template for use. The elevated temperatures inhibit reannealing of linear double-stranded DNA templates, such as PCR products, thus improving the effective amount of template available for reaction. False stops are also less frequent since annealing and polymerization are both performed at elevated temperatures, where the stringency of primer hybridization is greater and secondary structure of the template is reduced. Fluorescent labelled (5'-IRD-800) sequencing primers allow to read the sequence using laser scanner. Typically $4 \mu$ reaction contained:

Plasmid DNA (40-80 $\mathrm{ng} / \mathrm{\mu l})$

Sequencing Primer $(1 \mathrm{pmol} / \mu \mathrm{l})$

$\mathrm{A} / \mathrm{C} / \mathrm{G} / \mathrm{T}$ reagent (Amersham)
$2.5 \mu \mathrm{l}$

$0.5 \mu \mathrm{l}$

$1 \quad \mu l$ (different in each reaction)

Components were pipetted on ice into "Thin-Walled PCR Tubes" (Boerhinger, Mannheim) and overlayed with mineral oil (Sigma, Munich). Reaction was done in Biometra TRIO-Thermoblock according to following PCR temperature profiles depending on sequencing primer used:

Cycles

$\begin{array}{llll}\text { M13reverse } & 95^{\circ} \mathrm{C} / 5 \mathrm{~min} & 95^{\circ} \mathrm{C} / 30 \text { sec., } 60^{\circ} \mathrm{C} / 20 \text { sec., } 70^{\circ} \mathrm{C} / 45 \mathrm{sec} . & 30 \\ \text { T7promoter } & 95^{\circ} \mathrm{C} / 5 \mathrm{~min} & 95^{\circ} \mathrm{C} / 30 \text { sec., } 55^{\circ} \mathrm{C} / 20 \text { sec., } 70^{\circ} \mathrm{C} / 45 \mathrm{sec} . & 30 \\ \text { CMVpromoter } & 95^{\circ} \mathrm{C} / 5 \mathrm{~min} & 95^{\circ} \mathrm{C} / 30 \text { sec., } 57^{\circ} \mathrm{C} / 20 \text { sec., } 70^{\circ} \mathrm{C} / 45 \mathrm{sec} . & 30 \\ \text { Luciferase gene } & 95^{\circ} \mathrm{C} / 5 \mathrm{~min} & 95^{\circ} \mathrm{C} / 30 \text { sec., } 49^{\circ} \mathrm{C} / 20 \text { sec., } 70^{\circ} \mathrm{C} / 45 \mathrm{sec} . & 30\end{array}$

Tab. 4. Temperature profiles of the cylic sequencing reactions. The primers used for sequencing reaction are indicated. Also are shown the temperatures, the times for each step and the number of cycles.

Samples of the sequencing reaction were mixed with $1 \mu$ of Sequencing Stop Buffer (Amersham-Pharmacia, Braunschweg) and denatured for 3 min before loading on the sequencing polyacrylamide gel. 
Sequencing polyacrylamide gel electrophoresis

To separate DNA fragments with very small molecular weight differences (single nucleotide) as is required in the sequencing, a denaturing polyacrylamide gel electrophoresis was used with urea as a denaturing agent. The gel was prepared using SequaGel XR-Acrylamide kit (Biozym, Hess. Oldendorf) in total volume of 40 $\mathrm{ml}$ :

SequaGel XR-Acrylamid solution $32 \mathrm{ml}$

SequaGel complete buffer reagent $8 \mathrm{ml}$

DMSO $400 \mu \mathrm{l}$ APS (10\%) $300 \mu \mathrm{l}$

After addition of APS the gel mix was poured in to a casting frame (Biozym, Hess. Oldendorf) with $0.25 \mathrm{~mm}$ spacer thickness, and allowed to polymerise for ca. $2 \mathrm{~h}$. After polymerisation the gel was fixed onto sequencing apparatus (Li-Cor 4000 , MWG-Biotech, Ebersberg) and pre-run for $30 \mathrm{~min}(1500 \mathrm{~V})$ to achieve the denaturing temperature $\left(50^{\circ} \mathrm{C}\right) .4 \mu \mathrm{l}$ of the sequencing reaction with $1 \mu \mathrm{l}$ of the loading buffer (USB/Amersham, Braunschweg) were denaturated $\left(95^{\circ} \mathrm{C}, 3 \mathrm{~min}\right.$ ) and directly loaded into the gel. Electrophoresis was run in $1 \mathrm{x}$ TBE buffer under $1500 \mathrm{~V}$ for ca. $16 \mathrm{~h}$. The sequences was automatically scanned by sequencing laser (fluorescently labelled sequencing primers were used). Reading of sequence was done by software attached to the sequencer (Data Collection, Li-Cor Inc., Lincoln, USA). The sequences were analysed further by the GCG software package (2.30).

\subsection{RNA isolation from animal tissues}

Pax6 transcript analysis by RT-PCR was performed using total RNA isolated from murine tissues: whole brain, cerebellum, eye, whole pancreas, pancreatic islets. The embryonic poly $(A)^{+}$RNA was also used which was obtained from Luc St-Onge (Develogen, Göttingen). Total RNA purification was done with the RNeasy Mini Kit (Qiagen, Hilden). $20-80 \mathrm{mg}$ of frozen $\left(-80^{\circ} \mathrm{C}\right)$ tissue was used. Following protocol from the Qiagen manual was used:

1. The frozen tissue was homogenised by mortar and pestle in liquid $N_{2}$. Tissue powder was transferred into $\mathrm{N}_{2}$-cooled, E-tube. The liquid $\mathrm{N}_{2}$ was let to evaporate. 
2. A $1.9 \mathrm{ml}$ of the Buffer RLT was added to lyse the homogenate. After vortexing for 5 sec. the lysate was applied on the QIAshredder Spin Column (further homogenisation) and centrifuged (2 min at $4^{\circ} \mathrm{C}, 14000 \mathrm{rpm}$ ) (Eppendorf $5415 \mathrm{C}$ ).

3. The flow-through from the QIAshredder Spin Column was centrifuged for $5 \mathrm{~min}$, $14000 \mathrm{rpm}, 4^{\circ} \mathrm{C}$ and the supernatant was taken for further steps.

4. A 1 volume of $70 \%$ ethanol was added to the supernatant (ca. $1.9 \mu \mathrm{l}$ ) and after vortexing for $5 \mathrm{sec}$. the mixture was applied on the RNeasy Spin Column. The column was centrifuged for $5 \mathrm{~min}$ at RT, $14000 \mathrm{rpm}$ and flow-through was discarded.

5. A $3.8 \mathrm{ml}$ of the Buffer RW1 was applied and the column was again centrifuged (as before) to wash.

6. The same washing step was repeated twice with $2.5 \mathrm{ml}$ of the Buffer RPE. After the second wash column was centrifuged empty to let it dry.

7. Elution of RNA was done twice with $30 \mu \mathrm{l}$ of sterile, RNase-free water (column was let standing for $1 \mathrm{~min}$ and then centrifuged for $5 \mathrm{~min}, 14000 \mathrm{rpm}$ at RT).

8. Concentration and purity of total RNA preparation was estimated spectrophotometriacally by measuring $\mathrm{OD}_{260} / \mathrm{OD}_{280}$ ratio (Shimadzu UV -160 Spectrophotometer). Aliquots of $10 \mu \mathrm{l}$ were stored at $-80^{\circ} \mathrm{C}$.

Composition of buffers is patent pending and was not published by Qiagen company.

\subsection{Protein expression in bacteria}

Full length PAX6 and PAX6 Paired Domain GST fusion proteins were cloned and bacterially expressed using GST Gene Fusion Vector - pGEX-2T, and BL21(DE3)pLys strain of E. coli. This system is designed for inducible, high-level intracellular expression of proteins as fusions with Schistosoma japonicum glutathione S-transferase (GST). All of the GST Gene Fusion Vectors (pGEX-2T) include the following features: a tac promoter for inducible, high-level expression, an internal lac $1^{q}$ gene for use in any $E$. coli host. Additionally these vectors encode thrombin, factor Xa or PreScission Protease recognition sites for cleaving the desired protein from the fusion product. Collectively, the pGEX vectors provide all three translational reading frames beginning with the EcoR I restriction site. The GST moiety provides an affinity tag for fusion protein purification using Glutathione 
Sepharose 4B. Highly pure proteins are eluted under mild conditions which preserve protein antigenicity and functional activity. The following characteristics of the pGEX system was described by its producer (Amersham / Pharmacia): Induction: tac promoter is inducible with 1-5 mM IPTG. Expression: Proteins are expressed as fusion protein, with the 26-kDa glutathione S-transferase (GST). The GST gene contains an ATG and ribosome-binding site and is under control of the tac promoter. A translation terminator is provided in each reading frame. The resulting fusion protein can be purified using the GST Purification Module. Host(s): E. coli. The plasmid provides lac $1^{9}$ repressor; supplied with E. coli BL21. Selectable marker(s): Plasmid confers resistance to $100 \mu \mathrm{g} / \mathrm{mi}$ ampicillin. The GST-Pax6 full lenght fusion protein was bacterially expressed and purified according to the following protocol:

1. Freshly thawed BL21(DE3)pLys E.coil bacteria were transformed with pGEX-2TPAX6 FL (GST-Pax6 full lenght vector) as described 2.20.

2. A $300 \mu \mathrm{l}$ of transformation mixture was inoculated to $20 \mathrm{ml}$ of LB medium containing $100 \mu \mathrm{g} / \mathrm{ml}$ ampicillin and $34 \mu \mathrm{g} / \mu \mathrm{l}$ chloramphenicol. Culture was grown for $12 \mathrm{hrs}, 37^{\circ} \mathrm{C}, 225 \mathrm{rpm}$.

3. The $20 \mathrm{ml}$ culture was used to inoculate $1 \mathrm{~L}$ of $L B$ medium with amp, $C A$ as above and was grown till $\mathrm{OD}_{600}=0.6$. Reference sample (non-induced) of $1 \mathrm{ml}$ was taken and culture was induced with IPTG to final concentration of $1 \mathrm{mM}$. After IPTG induction culture was further grown for additional $4 \mathrm{hrs}$ at $37^{\circ} \mathrm{C}, 200 \mathrm{rpm}$.

4. Culture was centrifuged to harvest bacteria for $15 \mathrm{~min}, 3500 \mathrm{rpm}, 4^{\circ} \mathrm{C}$ (Beckman JA20 Rotor) and pellet was resuspended in ice-cold 1x PBS Buffer (containing 1 $\mathrm{mM}$ DTT and $1 \mathrm{mM}$ PMSF). Suspension was frozen and stored overnight at $80^{\circ} \mathrm{C}$.

5. Frozen bacterial suspension was slowly thawed on ice for ca. 3 hrs and sonicated $10 \times 20 \mathrm{sec}$. pulses of 400W (Labsonic 1510, Braun, Melsungen). Sonication was done on ice-water with $30 \mathrm{sec}$. intervals between sonicating pulses to avoid sample overheating.

6. To homogenate NP-40 detergent was added to final concentration of $0.2 \%$ and sample was agitated at rocking platform (Mini Rocking Platform, Biometra, Göttingen) for $30 \mathrm{~min}$ at RT. Reference sample of $500 \mu \mathrm{l}$ was taken. 
7. Lysate was centrifuged for $10 \mathrm{~min}, 10000 \mathrm{rpm}, 4^{\circ} \mathrm{C}$ (Beckman JA20 Rotor). $10 \mu \mathrm{l}$ reference samples from pellet and supernatant were taken.

8. Supernatant was taken and $1 \mathrm{ml}$ of the prehydrated Glutathione Agarose Slurry (Sigma, Munich) was added. DTT was added to final concentration of $5 \mathrm{mM}$.

9. Suspension was agitated at rocking platform for $12 \mathrm{hrs}$ min at $4^{\circ}$ and then suspension was centrifuged for $2 \mathrm{~min}, 2000 \mathrm{rpm}, \mathrm{RT}$ (Heraeus Megafuge 1.0).

10. Pellet of agarose beads was washed by resuspension in $10 \mathrm{ml}$ of ice-cold $1 \mathrm{x}$ PBS Buffer (containing $1 \mathrm{mM}$ DTT and $1 \mathrm{mM} \mathrm{PMSF}$ ) and centrifugation for $2 \mathrm{~min}$, 2000 rpm, RT. Washing was repeated two more times. At each washing step 10 $\mu \mathrm{l}$ reference sample was taken.

11. Pellet was resuspended in $2-3 \mathrm{ml}$ of $1 \times$ PBS Buffer and transferred in to a chromatography column (Poly-Prep Chromatography Columns, Bio-Rad, Munich) and let to sediment for $15 \mathrm{~min}, \mathrm{RT}$.

12. Column was opened and eluted twice with $1.5 \mathrm{ml}$ of Elution Buffer collecting 200 $\mu$ fractions.

13. Each fraction was then colorimetrically assayed for protein content: $5 \mathrm{ml}$ of each fraction was mixed with $100 \mu \mathrm{l}$ "Coomasie Brilliant Blue" -G 250- Reagent (BioRad, Munich) and each saple pipetted into micro-well plate (96). After $10 \mathrm{~min}$ of colour development, the elution profile was estimated and fractions with the most protein content were pooled.

14. Pooled fractions were placed in dialysis tubing and dialysed twice against Dignam D Buffer for $2 \mathrm{hrs}, 4^{\circ} \mathrm{C}$.

15. After dialysis protein concentration was estimated using "Coomasie Brilliant Blue" -G 250- Reagent and BSA standard concentration/absorbtion plot. Samples were stored at $-80^{\circ} \mathrm{C}$.

\section{Dignam D Buffer}

$\begin{array}{ll}\text { HEPES (pH 7.5) } & 20 \mathrm{mM} \\ \text { Glycerol } & 20 \%(\mathrm{v} / \mathrm{v}) \\ \mathrm{KCl} & 0.1 \mathrm{M} \\ \text { EDTA }(\mathrm{pH} 8.0) & 0.2 \mathrm{mM} \\ \text { DTT } & 0.5 \mathrm{mM} \\ \text { PMSF } & 0.5 \mathrm{mM}\end{array}$




\section{Elution Buffer (pH 7.7)}

$\begin{array}{ll}\text { Glutathione } & 40 \mathrm{mM} \\ \text { Tris }(\mathrm{pH} 8.0) & 100 \mathrm{mM} \\ \mathrm{NaCl} & 120 \mathrm{mM} \\ \text { Triton X-100 } & 0.1 \%(\mathrm{v} / \mathrm{v}) \\ \text { Glycerol } & 20 \%(\mathrm{v} / \mathrm{v}) \\ \text { PMSF } & 1 \mathrm{mM} \\ \text { DTT } & 1 \mathrm{mM}\end{array}$

\section{Glutathione Agarose Slurry}

$800 \mathrm{mg}$ of Glutathione Agarose (Sigma, Munich) was suspended in $10 \mathrm{ml}$ of water to hydrate $\left(3 \mathrm{hrs}, 4^{\circ} \mathrm{C}\right)$ and then agarose was washed twice with $10 \mathrm{ml}$ of 1 XPBS and resuspended in $10 \mathrm{ml}$ of ice-cold 1x PBS Buffer (containing $1 \mathrm{mM}$ DTT and $1 \mathrm{mM}$ PMSF). The glutathione agarose sluryr was stored at $4^{\circ} \mathrm{C}$.

\subsection{Extraction of nuclear proteins (Schreiber-Schaffner method)}

Nuclear proteins were isolated from the InR1G9 cells. Per sample $60 \mathrm{~mm}$, fully confluent plates were used. The following protocol was used:

1. A 6-cm plate was washed with 5-8 $\mathrm{ml}$ ice-cold TBS Buffer.

2. Cells were removed by scraping in $2 \mathrm{ml}$ of ice-cold TBS Buffer and transferred to $15 \mathrm{ml}$ tube (Blue Max, Falcon, UK).

3. Plate was washed again with $8 \mathrm{ml}$ TBS Buffer and the cell suspension was added to the same $15 \mathrm{ml}$ tube.

4. Cells were centrifuged for $2 \mathrm{~min}, 1600 \mathrm{rpm}, \mathrm{RT}$ (Heraeus Megafuge 1.0).

5. Pellet was resuspended in $1 \mathrm{ml}$ ice-cold TBS Buffer, transferred to E-tube and centrifuged for $2 \mathrm{~min} 1600 \mathrm{rpm}, 4^{\circ} \mathrm{C}$ (Eppendorf 5415C).

6. Pellet was resuspended in $400 \mu \mathrm{l}$ ice cold BUFFER A and incubated for $15 \mathrm{~min}$ on ice.

7. $25 \mu \mathrm{l}$ of $10 \%$ NONIDET p40 was added and sample was vortexed for $10 \mathrm{sec}$.

8. Sample was centrifuged for $2 \mathrm{~min}, 6000 \mathrm{rpm}, 4^{\circ} \mathrm{C}$ (Eppendorf 5415C) and supernatant containing cytoplasmatic fraction was discarded. 
9. Pellet was resuspended in $50 \mu \mathrm{l}$ ice-cold BUFFER $\mathrm{C}$ and shaken on rotary shaker $300 \mathrm{rpm}, 4^{\circ} \mathrm{C}$ for $20 \mathrm{~min}$.

10. Sample was centrifuged for $4 \mathrm{~min}, 14000 \mathrm{rpm}, 4^{\circ} \mathrm{C}$.

11. Supernatant was collected (ca. $55 \mu \mathrm{l}$ ) and stored in $-80^{\circ} \mathrm{C}$.

For Western blot analysis $15 \mu \mathrm{l}$ from the above sample were used. In case of EMSA 1-3 $\mu \mathrm{l}$ of freshly prepared extracts were used.

\section{Buffer A}

Buffer C

$\begin{array}{llllll}\text { HEPES pH 7.9 } & 10 & \mathrm{mM} & \text { HEPES pH 7.9 } & 20 & \mathrm{mM} \\ \text { KCI } & 10 & \mathrm{mM} & \text { NaCl } & 400 & \mathrm{mM} \\ \text { EDTA } & 0.1 & \mathrm{mM} & \text { EDTA } & 1 & \mathrm{mM} \\ \text { EGTA } & 0.1 & \mathrm{mM} & \text { EGTA } & 1 & \mathrm{mM} \\ \text { DTT } & 1 & \mathrm{mM} & \text { DTT } & 1 & \mathrm{mM} \\ \text { PMSF } & 0.5 & \mathrm{mM} & \text { PMSF } & 1 & \mathrm{mM}\end{array}$

TBS Buffer: $8 \mathrm{~g} \mathrm{NaCl}, 0.2 \mathrm{~g} \mathrm{KCl}, 3 \mathrm{~g}$ TRIS were dissolved in $800 \mathrm{ml}$ water. $\mathrm{pH}$ was adjusted to $7.4(\mathrm{HCl})$ and water added to $1000 \mathrm{ml}$.

\subsection{SDS-polyacrylamide gel electrophoresis}

Analytical SDS gel electrophoresis of proteins is carried out in polyacrylamide gels under conditions that ensure dissociation of the proteins into their individual polypeptide subunits and that minimize aggregation. The strongly anionic detergent SDS is used in combination with a reducing agent (B-ME) and heat to dissociate the proteins before they are loaded on the gel. The denatured polypeptides bind SDS and become negatively charged. Because the amount of SDS bound is almost always proportional to the molecular weight of the polypeptide and is independent of its sequence, SDS-polypeptide complexes migrate through polyacrylamide gels in accordance with the size of the polypeptide. By using markers of known molecular weight, it is therefore possible to estimate the molecular weight of the polypeptide chain(s). In most cases, SDS-polyacrylamide gel electrophoresis is carried out with a discontinuous buffer system in which the buffer in the reservoirs is of a different $\mathrm{pH}$ 
and ionic strength from the buffer used to cast the gel. After migrating through a stacking gel of high porosity, the complexes are deposited in a very thin zone (or stack) on the surface of the resolving gel. The ability of discontinuous buffer systems to concentrate all of the complexes in the sample into a very small volume greatly increases the resolution of SDS-polyacrylamide gels. The sample and the stacking gel contain Tris- $\mathrm{Cl}(\mathrm{pH}$ 6.8), the upper and lower buffer reservoirs contain Tris-glycine ( $\mathrm{pH}$ 8.3), and the resolving gel contains Tris - $\mathrm{Cl}(\mathrm{pH}$ 8.8). All components of the system contain $0.1 \%$ SDS (Laemmli 1970). In this study 4\% "stacking" gel and $10 \%$ resolving gel were prepared and electrophoresis was run in Mighty Small-System apparatus,SE 250 (Hoefer, San Francisco) in 1x Tank Buffer at constant current of $170 \mathrm{~mA}$. Before loading the protein samples were mixed with Loading Buffer and denatured by incubation for $5 \mathrm{~min}$ at $95-100^{\circ} \mathrm{C}$ (boiling water bath). Per lane 15-17 $\mu \mathrm{l}$ of samples were loaded. After electrophoresis gel was stained with Coomasie-Blue Solution for 4-10 hrs at RT. Destaining was done by incubation in Destain Solution for 4-8 hrs changing the solution 3-5 times. Destained gel was dried by sealing it between porous cellophane sheets (Pharmacia, Hoefer, San Francisco) and letting stand at RT for $12 \mathrm{~h}$.

\section{$10 \%$ Separating Gel}

Acrylamide Mix

Resolving Buffer (1.5M Tris pH 8.8)

Water

$10 \%$ SDS

$10 \%$ APS $(0.1 \mathrm{~g} / 1 \mathrm{ml})$

TEMED

\section{4\% Stacking Gel}

Acrylamide Mix

Stacking Buffer (0.5M Tris pH 6.8)

Water

$10 \%$ SDS

$10 \%$ APS $(0.1 \mathrm{~g} / 1 \mathrm{ml})$

TEMED
$3.33 \mathrm{ml}$

$2.5 \mathrm{ml}$

$4 \mathrm{ml}$

$100 \mu \mathrm{l}$

$100 \mu \mathrm{l}$

$6 \mu \mathrm{l}$

$0.67 \mathrm{ml}$

$1.25 \mathrm{ml}$

$2.98 \mathrm{ml}$

$50 \mu \mathrm{l}$

$50 \mu \mathrm{l}$

$2.4 \mu \mathrm{l}$ 
Acrylamide Mix

Acrylamide

$29.2 \mathrm{~g}$

Bisacrylamide

$0.8 \mathrm{~g}$

Water

$100 \mathrm{ml}$

\section{Loading Buffer (5x)}

Tris (pH7.4)

$150 \mathrm{mM}$

Bromophenolblue

$0.2 \%(\mathrm{w} / \mathrm{v})$

SDS

$5 \%$

Glycerol

$10 \%$

B-ME

$12 \%$

Tank Buffer (5X)

Tris (pH 8.3)

$25 \mathrm{mM}$

Glycine

$192 \mathrm{mM}$

SDS

$0.1 \%$

\subsection{Western blot analysis}

In Western blotting electrophoretically separated components are transferred from a gel to a solid support and probed with antibodies that react specifically with antigenic epitopes displayed by the target protein attached to the solid support. In Western blotting, the samples to be assayed are solubilized with detergents and reducing agents, separated by SDS-polyacrylamide gel electrophoresis (2.25), and transferred to a solid support (usually a nitrocellulose filter). The filter is subsequently exposed to unlabeled antibodies specific for the target protein. Finally, the bound antibody is detected by one of several secondary immunological reagents ( ${ }^{125}$ I-labeled protein A or anti-immunoglobulin, or anti-immunoglobulin or protein A coupled to horseradish peroxidase or alkaline phosphatase). As little as 1-5 ng of an average-sized protein can be detected by western blotting. The following protocol was used:

1. InR1G9 cells were splitted the day before insulin treatment. The fully confluent, 6$\mathrm{cm}$ plates were used for each time point. $1 \mathrm{hr}$ before the insulin treatment the FCS-containing medium was withdrawn and a new medium with BSA and antibiotics was applied. Insulin was added in the desired intervals to each 6 -cm 
plate. After the insulin stimulation nuclear extracts were prepared as described (2.25). The nuclear extract samples were separated by SDS-PAGE $(15 \mu \mathrm{l}$ of extract loaded) (2.26) and the proteins were subject to Western blot.

2. The SDS gel was incubated for $20 \mathrm{~min}$ in Buffer $\mathrm{C}$. In this time membrane used for blotting (Hybond-ECL ${ }^{\mathrm{TM}}$, Nitrocellulose, Amersham) was incubated for few seconds in water and then for 15 min in Buffer B.

3. Proteins were electroblotted from the gel to the membrane using dry electroblotting apparatus (Scientific Equipment Workshop, Clinics of Goettingen University) under constant current of $70 \mathrm{~mA}$ for 1.5-2 $\mathrm{h}$ The arrangement of blotting stack was as follows (from "+" -bottom to "-" -top electrode): $2 x$ Whattman Paper in Buffer $A, 2 x$ Whattman Paper in Buffer $B$, membrane (in Buffer B), gel (in Buffer C), 4x Whattman Paper in Buffer C, 15-30x Whattman Paper (dry).

4. After electroblotting the membrane was blocked (unspecific protein binding) by incubation for 2 hrs at RT in Blocking Solution. Membrane was then washed three times in TBST Buffer for 20 min at RT (Mini Rocking Platform).

5. Primary Pax6 antibody (goat polyclonal IgG, Santa Cruz Biotechnology, Santa Cruz) was applied to membrane (diluted in TBST 1:600, final concentration 0.33 $\mu \mathrm{g} / \mathrm{ml})$. Incubation was done for $16 \mathrm{hrs}, 4^{\circ} \mathrm{C}$ (Mini Rocking Platform).

6. Membrane was then washed three times in TBST Buffer for 20 min at RT (Mini Rocking Platform). Membrane was incubated with secondary antibody: anti-goat IgG-HRP (coupled to Horse Radish Peroxidase) which was diluted in TBST Buffer 1:15000 (final concentration $6.67 \mathrm{ng} / \mathrm{ml}$ ). Incubation was done for $30 \mathrm{~min}$, RT.

7. Membrane was then washed three times in TBST Buffer for 20 min at RT (Mini Rocking Platform).

8. The blot was visualised using ECL Western Blotting System - AmershamPharmacia, Vienna (HRP-catalysed chemiluminescence detection). Shortly, the membrane was incubated for $1 \mathrm{~min}$ in $5 \mathrm{ml}$ of developing mixture $(2.5 \mathrm{ml}$ Solution A and $2.5 \mathrm{ml}$ Solution B) and then was wrapped in Saran foil and exposed to Roentgen films (Hyperfilm MP, Amersham, Braunschweg) for time intervals ranging from 0.5 to $5 \mathrm{~min}$. The films were developed as described (2.18) and air dried. 
Buffer A (pH 11.3)

Tris

$0.3 \mathrm{M}$

Methanol

$20 \%(v / v)$

Buffer B (pH 10.6)

Tris

Methanol

$25 \mathrm{mM}$

$20 \%(v / v)$

Buffer C (pH 9.0)

Tris

$25 \mathrm{mM}$

Methanol

$20 \%(v / v)$

Blocking Solution: TBST Buffer with 10\% (w/v) Skim Milk Powder (Fluka, Buchs)

\section{$\underline{\text { TBST Buffer }}$}

Tris $(\mathrm{pH} \mathrm{8.0)} \quad 10 \quad \mathrm{mM}$

$\mathrm{NaCl} \quad 150 \mathrm{mM}$

Tween-20 $\quad 0.05 \%(\mathrm{v} / \mathrm{v})$

\subsection{EMSA (electro-phoretic mobility shift assay)}

EMSA technique was used for investigation of protein-DNA interactions. It relies on the observation that protein-DNA complexes migrate in non-denaturating acrylamide gels slower than the free, not protein-bound DNA fragment. In the experiments nuclear extracts from the InR1G9 cells (2.24) were used as well as the bacterially expressed GST-PAX6 paired box fusion protein (2.23). The probe was radioactively labelled using $\left(\alpha^{-32} \mathrm{P}\right)$-dCTP.

\section{Binding reaction}

The binding reaction was set up on ice in total volume of $20 \mu \mathrm{l}$ as presented below. The binding buffer, nuclear extract or bacterially expressed protein plus poly $\mathrm{dl} / \mathrm{dC}$ were mixed first and incubated on ice for $10 \mathrm{~min}$. (non-specific competition). Then the probe was added and incubation was continued for another $15 \mathrm{~min}$. Reaction was 
stopped by addition of $4 \mu \mathrm{l}$ of $6 \mathrm{x}$ Stop Mix and immediately loaded on the nondenaturing polyacrylamid gel.

\section{Binding Reaction (added as described above)}

$5 x$ Binding Buffer

Nuclear Extract plus water

Poly dl/dC $(1 \mu \mathrm{g} / \mu \mathrm{l})$

Probe $(20000 \mathrm{cpm} / \mu \mathrm{l})$

1x Binding Buffer:

Hepes, pH 7.9

$\mathrm{KCl}$

EDTA, pH 8.0

DTT

Glycerol
$4 \mu \mathrm{l}$

$11 \mu \mathrm{l}$

$4 \mu \mathrm{l}$

$1 \mu \mathrm{l}$

$20 \mathrm{mM}$

$140 \mathrm{mM}$

$1 \mathrm{mM}$

$0.5 \mathrm{mM}$

$10 \%(\mathrm{v} / \mathrm{v})$

\section{Non-denaturating Gel Electrophoresis}

The binding reaction mixture after addition of stop buffer was resolved in the nondenaturating polyacrylamide, $5 \%$ gel (1XTBE). The gel was prepared by pouring the gel mix in to a set of glass plates $(15 \times 10 \mathrm{~cm}$ ) placed in a gel casting base (SE 600, Hoefer, San Francisco, USA). The gel was run prior to the loading of the samples for $30 \mathrm{~min}$. After loading the samples, the electrophoresis was run for 1-2 hrs at room temperature, under the voltage of $180 \mathrm{~V}$. Then the gel was transferred on Whattman paper, wrapped with plastic foil and dried under vacuum $\left(70^{\circ} \mathrm{C}, 1 \mathrm{hr}\right)$. Dry gel was subject to autoradiography.

\section{5\% Gel Composition}

$\begin{array}{ll}38 \% / 2 \% \text { Acrylamide/Bisacrylamide } & 6.25 \mathrm{ml} \\ 5 \times \text { TBE } & 5 \mathrm{ml} \\ \text { Water } & 38.5 \mathrm{ml} \\ 10 \% \text { APS } & 250 \mu \mathrm{l} \\ \text { TEMED } & 25 \mu \mathrm{l}\end{array}$




\subsection{Eucariotic cells culture methods}

All procedures with eukariotic cell cultures like culturing and transfection were done under sterile conditions using sterile hood (Heraeus, Hamburg). Solutions and media were sterilized by autoclaving or filtration and were prewarmed before use $\left(37^{\circ} \mathrm{C}\right.$ water bath). All glassware items like pipettes and bottles were autoclaved, and bottles with liquids were cleaned each time before placing under the sterile hood by whipping with $70 \%$ isopropanol. All centrifugations of cell suspension during transfection or propagating procedures were done for $2 \mathrm{~min}, 1300 \mathrm{rpm}$ at RT (Megafuge 1.0, Heraeus, Hamburg).

\section{Cell culture}

InR1G9 and JEG-3 cell lines were grown in $30 \mathrm{ml}$ of culture medium (2.7) on 15-cm plates $(2.3)$ in $5 \% \mathrm{CO}_{2}, 97 \%$ humidity atmosphere $\left(37^{\circ} \mathrm{C}\right)$, in cell culture incubator (Steri-Kult Incubator, Labotect $\mathrm{GmbH}$, Göttingen). Cells were grown to $80-90 \%$ confluency and then propagated as follows: Plates were washed with 10-15 $\mathrm{ml} 1 \mathrm{x}$ PBS. Then $3 \mathrm{ml}$ of Trypsin/EDTA (GIBCO BRL, Karlsruhe) was applied to dis-attach the cells. After incubation for $2-3 \mathrm{~min}$ at $37^{\circ} \mathrm{C}$, plates were shaken and cells were washed off from the plate with $10-15 \mathrm{ml}$ of culture medium and transferred to $50 \mathrm{ml}$ tube (Blue Max, Falcon, Becton). The suspension was centrifuged and the pellet was resuspended in $10 \mathrm{ml}$ of culture medium and again centrifuged. Cells were resuspended in $30 \mathrm{ml}$ of culture medium in desired ratio and suspension was plated out.

\section{DEAE-Dextran transfection}

Positively charged DEAE-Dextran forms complexes with negatively charged DNA which then is taken through the cell plasma membrane. This method was used to transfect the InR1G9 cells. One $15-\mathrm{cm}$ plate was taken at $80-90 \%$ confluency. The plate was washed with $15 \mathrm{ml}$ of $1 \times$ PBS, then $3 \mathrm{ml}$ of Trypsin/EDTA was applied. After incubation for $2-3 \mathrm{~min}$ at $37^{\circ} \mathrm{C}$, the plate was shaken to dis-attach the cell. The cells were washed off with culture medium (containing no serum) and transferred to $50 \mathrm{ml}$ tube (Blue Max, Falcon, Becton). After centrifugation, the cell pellet was resuspended in 20-30 $\mathrm{ml}$ Buffer TD and centrifuged again (wash step). Cell pellet was then resuspended TD Buffer in amount of $1 \mathrm{ml}$ TD Buffer per 6-cm plate. To the 
cell suspension DEAE-Dextran solution was added ( $5 \mu \mathrm{l}$ per 6 -cm plate) and after gentle mixing, cell suspension was transferred to $50 \mathrm{ml}$ tubes containing DNA to be transfected. After gentle mixing DNA/cell suspension was incubated for $15 \mathrm{~min}$ at RT to allow DNA uptake, and then serum-containing culture medium $(1 \mathrm{ml}$ per $\mathrm{ml}$ of cell suspension) was added to stop the transfection. Cells were centrifuged and washed with culture medium (5-10 $\mathrm{ml}$ per tube). After final centrifugation cells were suspended in culture medium (5 $\mathrm{ml}$ per $6-\mathrm{cm}$ plate) and plated out. Cells were harvested $48 \mathrm{hrs}$ after transfection and luciferase and GFP reporter gene assays were performed (see below). As control for transfection efficiency and squelching pGFPtpz-cmv [R] (2.10) was cotransfected (500ng per 6-cm plate). Reporter gene constructs were transfected in amount of $2 \mu \mathrm{g}$ per $6-\mathrm{cm}$ plate (otherwise indicated) and total DNA content was kept constant throughout all groups in a given experiment by balancing with pBS DNA.

\section{$\underline{\text { TD Buffer }}$}

$\begin{array}{lll}\text { Tris }(\mathrm{pH} \mathrm{7.4)} & 25 & \mathrm{mM} \\ \mathrm{NaCl} & 140 & \mathrm{mM} \\ \mathrm{KCl} & 5 & \mathrm{mM} \\ \mathrm{K}_{2} \mathrm{HPO}_{4} & 0.7 & \mathrm{mM}\end{array}$

DEAE-Dextran: $60 \mathrm{mg} / \mathrm{ml}$ in water. Sterilised by filtration.

$\underline{\text { Insulin solution }(10 \mu \mathrm{M})}$

$\begin{array}{lll}\text { Porcine Insulin } & 3 & \mathrm{mg} / 50 \mathrm{ml} \\ \text { BSA } & 100 & \mathrm{mg} / 50 \mathrm{ml}\end{array}$

Insulin was dissolved in $0.9 \% \mathrm{NaCl}$ solution $(\mathrm{pH} 2.8)$. The $\mathrm{pH}$ of the solution was neutralised by addition of $1 \mathrm{~N} \mathrm{NaOH}$ and then BSA was added. The aliquots of $1 \mathrm{ml}$ were stored at $80^{\circ} \mathrm{C}$.

\section{Calcium phosphate transfection}

In this protocol a coprecipitate of DNA and calcium phosphate is formed, which is taken to the cell through phagocytosis. This method was used to transfect the JEG-3 cells. The cells were splitted from $15-\mathrm{cm}$ culture plates $(80-90 \%$ confluency) to $6-\mathrm{cm}$ plates 20-24 hrs before transfection (one 15-cm plate per 10-12 6-cm plates) and 
grown under standard conditions. DNA/calcium phosphate coprecipitate was prepared as follows: per $6-\mathrm{cm}$ plate $150 \mu \mathrm{l}$ of DNA solution (in water) was mixed with $150 \mu \mathrm{l}$ of $0.5 \mathrm{M} \mathrm{CaCl}_{2}$ solution and after thorough mixing $300 \mu \mathrm{l}$ of $2 \mathrm{x} \mathrm{HBS}$ was added (slowly pipetting and simultaneous vortexing). The mixture was then incubated for 30 min at RT to allow formation of the coprecipitate. After incubation, the mixture containing the coprecipitate was vortexed and pipetted to $6-\mathrm{cm}$ plates $(600 \mu \mathrm{l}$ per plate). Cells were incubated with the DNA/calcium phosphate coprecipitate for $4 \mathrm{hrs}$ in $5 \% \mathrm{CO}_{2}, 97 \%$ humidity atmosphere $\left(37^{\circ} \mathrm{C}\right)$, Steri-Kult Incubator (Labortect $\mathrm{GmbH}$, Gorttingen). Then the precipitate-containing medium was discarded and cells were washed twice with $5 \mathrm{ml}$ of $1 \mathrm{x}$ PBS Buffer. The cells were grown for additional $48 \mathrm{~h}$ in fresh culture medium ( $5 \mathrm{ml}$ per plate) and then harvested. As control for transfection efficiency and squelching pGFPtpz-cmv [R] (2.10) was cotransfected (50ng per 6-cm plate). Reporter gene constructs were transfected in amount of $3 \mu \mathrm{g}$ per $6-\mathrm{cm}$ plate and total DNA content was kept constant through all groups in a given experiment by balancing with $\mathrm{pBS}$ DNA.

\section{$\underline{2 x \mathrm{HBS}(\mathrm{pH} 7.05)}$}

$\begin{array}{ll}\text { Hepes } & 50 \mathrm{mM} \\ \mathrm{NaCl} & 140 \mathrm{mM} \\ \mathrm{Na}_{2} \mathrm{HPO}_{4} & 1.5 \mathrm{mM}\end{array}$

\section{The insulin treatment}

The InR1-G9 cells were treated with insulin. In a standard procedure, the cells were incubated for $24 \mathrm{~h}$ after transfection in a medium containing FCS and antibiotics. Then, $23 \mathrm{~h}$ before harvesting, the medium was withdrawn and a new medium was applied containing BSA and antibiotics. $24 \mathrm{~h}$ before harvesting insulin was applied: 5 $\mu \mathrm{l}$ of $10 \mu \mathrm{M}$ solution per $6-\mathrm{cm}$ plate (final conc. $10 \mathrm{nM}$ ) and cells were returned to a incubator.

In case of the Western blot or EMSA analysis the cells were treated with insulin in similar way. After application of the medium with BSA insulin was pipetted in the time intervals as indicated in a given experiment. 
Cell extract preparation

Cells were harvested 48-50 hrs after transfection. 6-cm plates were washed twice with 2-3 $\mathrm{ml}$ of ice-cold $1 \times$ PBS buffer. $1 \mathrm{ml}$ of a "Scraping Buffer" was then applied to the each $6-\mathrm{cm}$ plate. Cells were scraped with rubber scraper and the cell suspension was transferred to Eppendorf tubes standing on ice. Each plate was washed with 0.5 $\mathrm{ml}$ of "Scraping Buffer" and suspension transferred to the same Eppendorf tube. Cells were centrifuged for $5 \mathrm{~min}, 6000 \mathrm{rpm}, 4^{\circ} \mathrm{C}$ (Eppendorf 5415C). The cell pellet was resuspended in $150 \mu$ of Potasium Phosphate Buffer. Cells were then disrupted by three cycles of freezing and thawing (liquid nitrogen $/ 37^{\circ} \mathrm{C}$ water bath). The lysate was vortexed for $2 \mathrm{sec}$. and centrifuged ( $5 \mathrm{~min}, 14000 \mathrm{rpm}, 4^{\circ} \mathrm{C}$ ). The cleared lysate was directly used for the luciferase or the GFP reporter gene assay (see below).

"Scraping Buffer"

$\begin{array}{lll}\text { Tris }(\mathrm{pH} 7.5) & 40 & \mathrm{mM} \\ \mathrm{NaCl} & 150 & \mathrm{mM} \\ \text { EDTA }(\mathrm{pH} \mathrm{8.0)} & 1 & \mathrm{mM}\end{array}$

Potassium Phosphate Buffer ( $\mathrm{pH} 7.8)$

$\begin{array}{lrc}\mathrm{K}_{2} \mathrm{HPO}_{4} & 100 \mathrm{mM} \\ \mathrm{KH}_{2} \mathrm{PO}_{4} & 100 \mathrm{mM}\end{array}$

\section{Luciferase reporter gene assay}

Firefly luciferase enzyme catalyses oxydative decarboxylation of luciferin. This reaction is dependent on $\mathrm{Mg}^{2+}$ ions and ATP, and apart from AMP, $\mathrm{CO}_{2}$ and oxyluciferine, photons are produced. Light emission depends on the luciferase concentration, therefore luminometric measurement allows to estimate expression level of luciferase reporter gene. For the luciferase assay $50 \mu \mathrm{l}$ of cell extract (see above) was taken and mixed with $368 \mu$ of Assay Mix in luminometric tubes (Sarstedt, Nümbrecht). Tubes were vortexed and placed in a luminometer (AutoLumat LB 953, E\&G Berthold, Wildbach), where to each tube Luciferine Mix was injected and light emission in $560 \mathrm{~nm}$ was measured for $20 \mathrm{sec}$. One tube, 
containing only Luciferine Mix, served as reference sample to estimate the background level.

\section{Assay Mix}

Potassium Phosphate Buffer

$16.5 \mathrm{mM}$

Glycylglycine Buffer

$82.4 \%(v / v)$

DTT

$1.1 \mathrm{mM}$

ATP

$2.2 \mathrm{mM}$

$\underline{\text { Luciferine Mix (In Glycylglycine Buffer) }}$

Luciferine

$1 \mathrm{mM}$

DTT

$10 \mathrm{mM}$

\section{Glycylglycine Buffer}

Glycylglycine ( $\mathrm{pH} 7.8)$

$25 \mathrm{mM}$

$\mathrm{MgSO}_{4}$

$15 \mathrm{mM}$

EGTA

$4 \mathrm{mM}$

\section{GFP reporter gene assay}

The Green Fluorescent Protein (GFP) mutant (tpz) used in the assay is derived from jelly fish (Aequoria victoria). When irradiated with UV rays, GFP protein possesses capability of emission of green light (fluorescent absorption/emission) which is proportional to its concentration. In this work a GFP construct was used which is under control of a constitutive CMV promoter (pGFPtpz-cmv [R]). Transfection of this GFP construct served as a control of transfection efficiency and to monitor squelching (non-specific inhibition of luciferase reporter gene activity due to titration of transcriptional factors by cotransfected expression constructs). For GFP assay 50 $\mu \mathrm{l}$ of cell extracts (see above) were taken and pipetted into microplate (96 K, Greiner $\mathrm{GmbH}$, Frickenhausen). Microplates were read by FluoroCount (Packard) with excitation/emission wavelengths of $485 \mathrm{~nm}$ and $530 \mathrm{~nm}$ respectively. 


\subsection{Software}

(RT)PCR primer design, restriction mapping analysis, DNA/protein sequence analysis and databases searching was done using GCG package - "Genetics Computer Groups"- Software version 9.1 (GCG, Madison).

Statistic analysis and plotting graphs was done with Sigma Stat-Programmes, version 2.0 (Jandel Scientific GmbH, Erkrath). 


\section{RESULTS}

\subsection{The constructs generated in this study}

The constructs which were prepared in this study are summarised below in the Tab. 5. All of these constructs were verified by sequencing. The detailed description of the cloning strategies is presented in the "Materials and Methods" section (2.10 and 2.11).

Construct

Description

-350 (mutG3)GluLuc

-350 (mutG1)GluLuc

-350 (mutG1/G3)GluLuc

$-350(-150 /-91)$ GluLuc

GAL4-Pax6

GST-Pax6(FL)
Internal deletion of the G3 element.

Internal deletion of the $\mathrm{G} 1$ element.

Internal deletion of the $\mathrm{G} 1$ and $\mathrm{G} 3$ element.

Internal deletion of the G4 element.

Tab. 5. List of the constructs generated in this study. In the upper part of the table are shown the glucagon-reporter fusion gene constructs containing the -350 region with an internal deletion of regulatory element(s). The deletion was done by converting the respective elements into the GAL4-binding site. In the lower part are shown the expression constructs. 


\subsection{Pax6 gene expression in pancreatic islets as revealed by RT-PCR}

In order to analyse Pax6 gene expression a RT-PCR analysis was performed. Two primer pairs were used, one of which flanks the alternatively spliced exon 5a (Fig. 4).
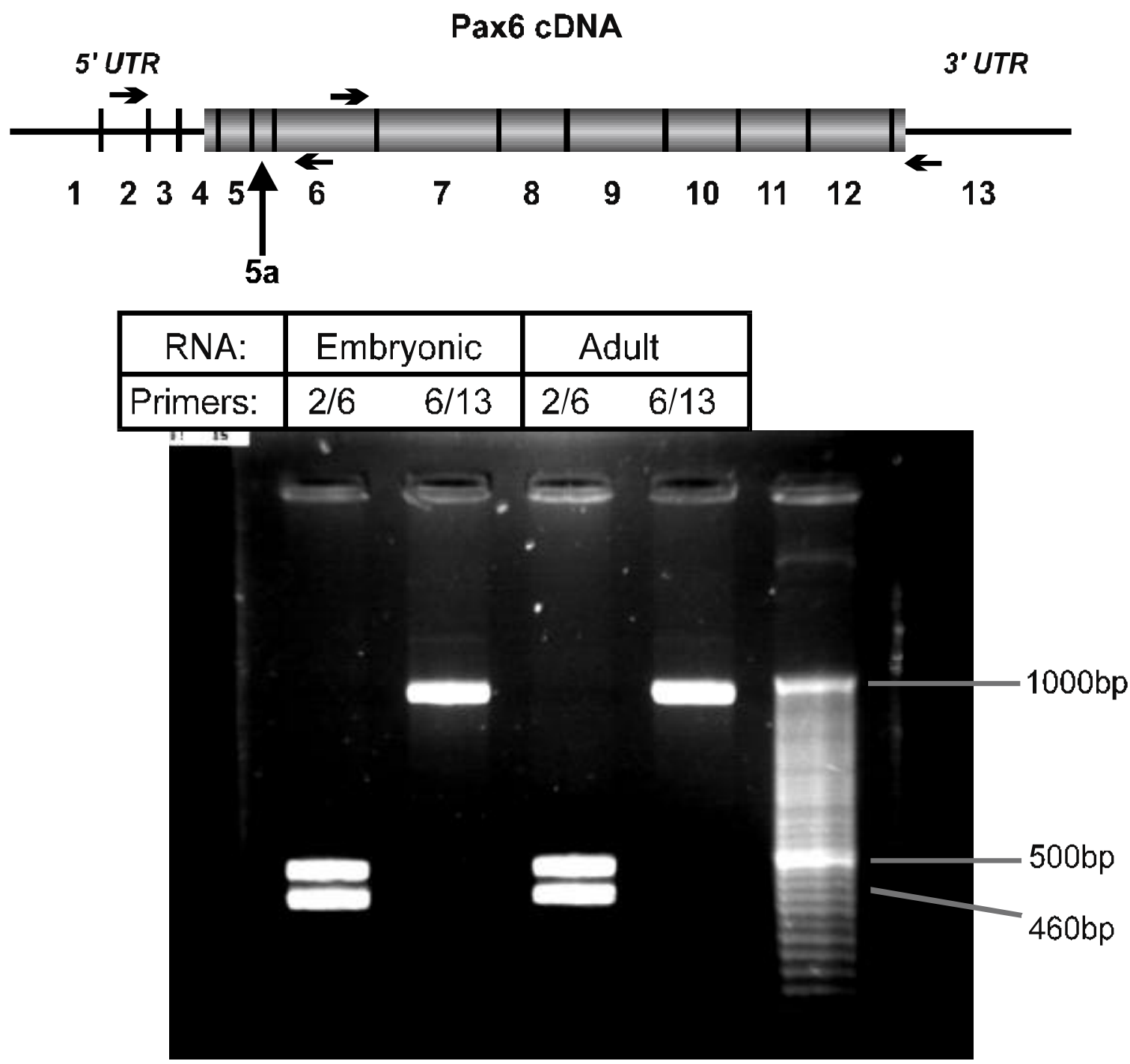

Fig. 4. Pax6 gene expression in mouse pancreas as revealed by RT-PCR. The upper part of the figure shows the relative positions of the two primer pairs used. The Pax6 CDNA is shown with the exons of the human gene. UTR - untranslated region. The sizes of the expected RT-PCR products are 499 and 457 bp with the primer pair targeting exon 2 and exon 6 (with and without exon $5 \mathrm{a}$ ), and 933 bp with the primer pair targeting exon 6 and exon 13. Total RNA from adult or embryonic poly $(A)^{+}$RNA (day $11.5 / 12.0$ p.c.) pancreas was used. The RT-PCR products were verified by subcloning and sequencing. 
With total RNA extracted from adult pancreas (Fig. 4) or from isolated pancreatic islets (data not shown), the primer pair targeting exon 2 and exon 6 detected pax 6 transcripts with and without exon 5a (499- and 457-bp fragment, respectively, Fig. 4). The primer pair that targets exon 6 and exon 13 (Fig. 4) generated a single product of expected size (933-bp fragment, Fig. 4). The RT-PCR products were verified by subcloning (T/A system, Invitrogen) and sequencing.

Similar results were obtained with poly $(A)^{+}$RNA extracted from the embryonic pancreata on days 11.5/12.0 p.c. (obtained from Luc St-Onge, Develogen, Goettingen) (Fig. 4). With total RNA extracted from the eye and cerebellum, both primer pairs generated products of the expected size for both splice variants (not shown), consistent with published reports of the Pax6 splice variants expression in the eye and central nervous system (Epstein et al.1994, Walther and Gruss 1991).

\subsection{Inhibition by insulin of Pax6-mediated transctriptional activity in InR1-G9 cells}

Inhibition by insulin of transcriptional activity conferred by a Pax6 binding site (G3A) from the glucagon promoter

It has been shown previously that, as a synthetic minienhancer in front of the minimal thymidine kinase promoter, four copies of the A domain from the G3 element, which contain a Pax6 binding site, confer strong transcriptional activity (Wrege et al.1995) in the glucagon-producing islet cell line InR1-G9.

In this study this is confirmed as four copies of the A domain from the G3 element raised the transcriptional activity $157 \pm 10$-fold $(n=6)$ over that of the thymidine kinase promoter alone. This G3A-dependent transcriptional activity was inhibited by insulin (10 nM) by about 30\% (Fig. 5). In contrast, three copies of the glucagon CRE or four copies of the G2 element did not confer insulin responsiveness to this heterologous promoter (Grzeskowiak et al. 2000). 


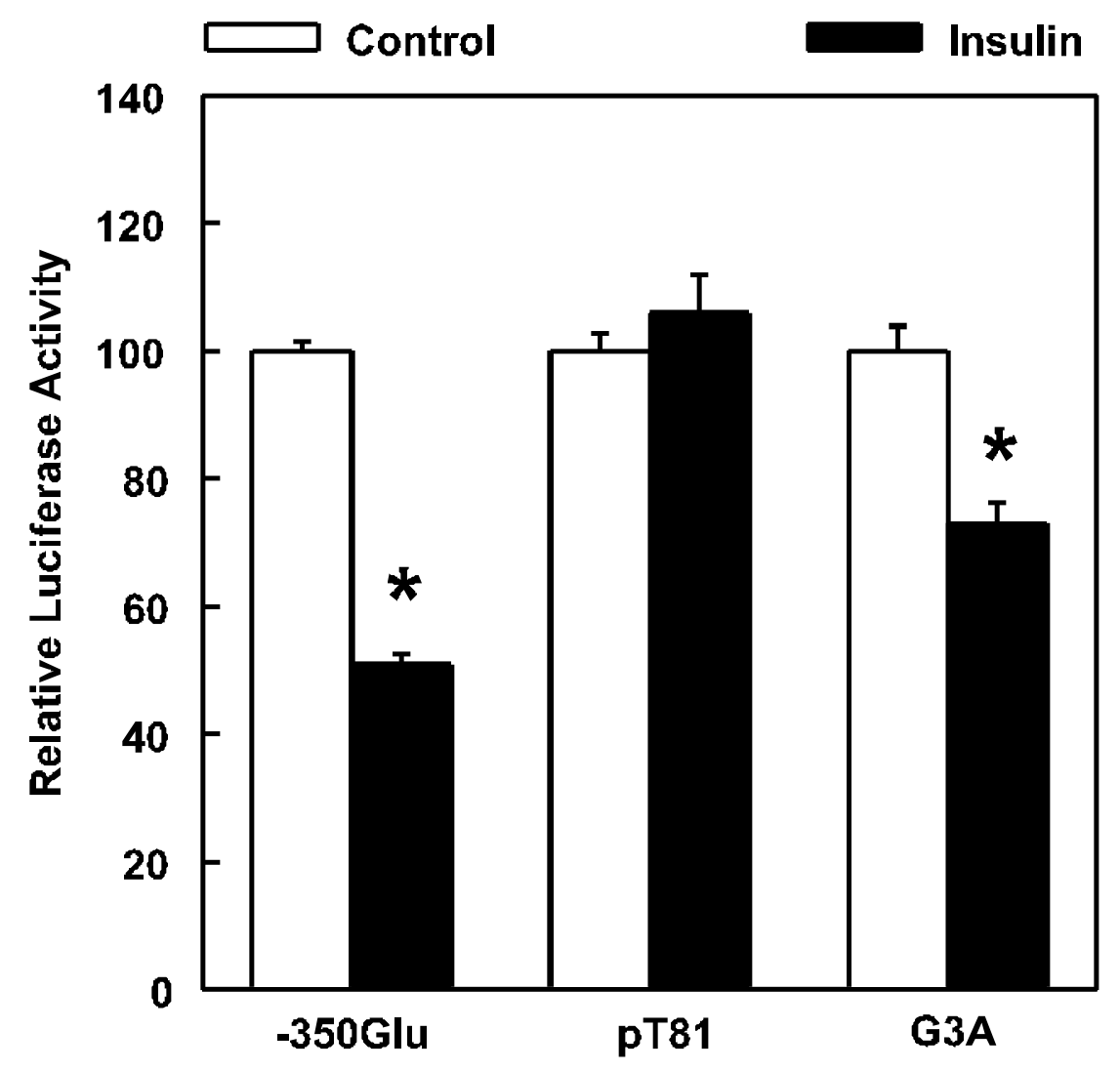

Fig. 5. Effect of insulin on the transcriptional activity conferred by the Pax 6 binding site G3A. The plasmids -350GluLuc, pT81Luc, and 4xG3A(T81)Luc were transfected into InR1-G9 cells, and the cells were treated with insulin $(10 \mathrm{nM})$ as indicated. Luciferase activity is expressed as percentage of the mean value, in each experiment, of the activity measured in the respective control (no treatment). Values are means $\pm S E$ of three independent experiments, each done in duplicate. ${ }^{*} P<0.005$ (Student's $t$-test).

Inhibition by insulin of Pax6-mediated activity as revealed in GAL4/viral E1B system As shown above four copies of G3A domain conferred insulin responiveness to the heterologous, minimal TK promoter. G3A contains the PISCES motif (Wrege et al.1995, Beimesche et al.1999, Knepel et al.1991) which binds the paired-domain transcriptional factor Pax6 (Beimesche et al.1999, Sander et al.1997).

To examine more directly, whether Pax6-dependent transcriptional activity is regulated by insulin, the GAL4 system was used. The GAL4 system allowed to avoid the background of the natively expressed Pax6 in InR1-G9 cells (which was the line used for experiments). A CMV-driven expression vector was constructed where full length Pax6 cDNA (without exon 5a) was fused to the GAL4 DNA-binding domain 
(amino acids 1-147). The GAL4 DNA-binding domain is derived from the yeast transcriptional factor GAL4. The GAL4-Pax6 fusion construct was transiently transfected into InR1-G9 cell line together with a luciferase reporter gene placed under control of a minimal, viral E1B promoter and five copies of a GAL4-binding site (5xGal4(E1B)Luc) (Fig. 6).
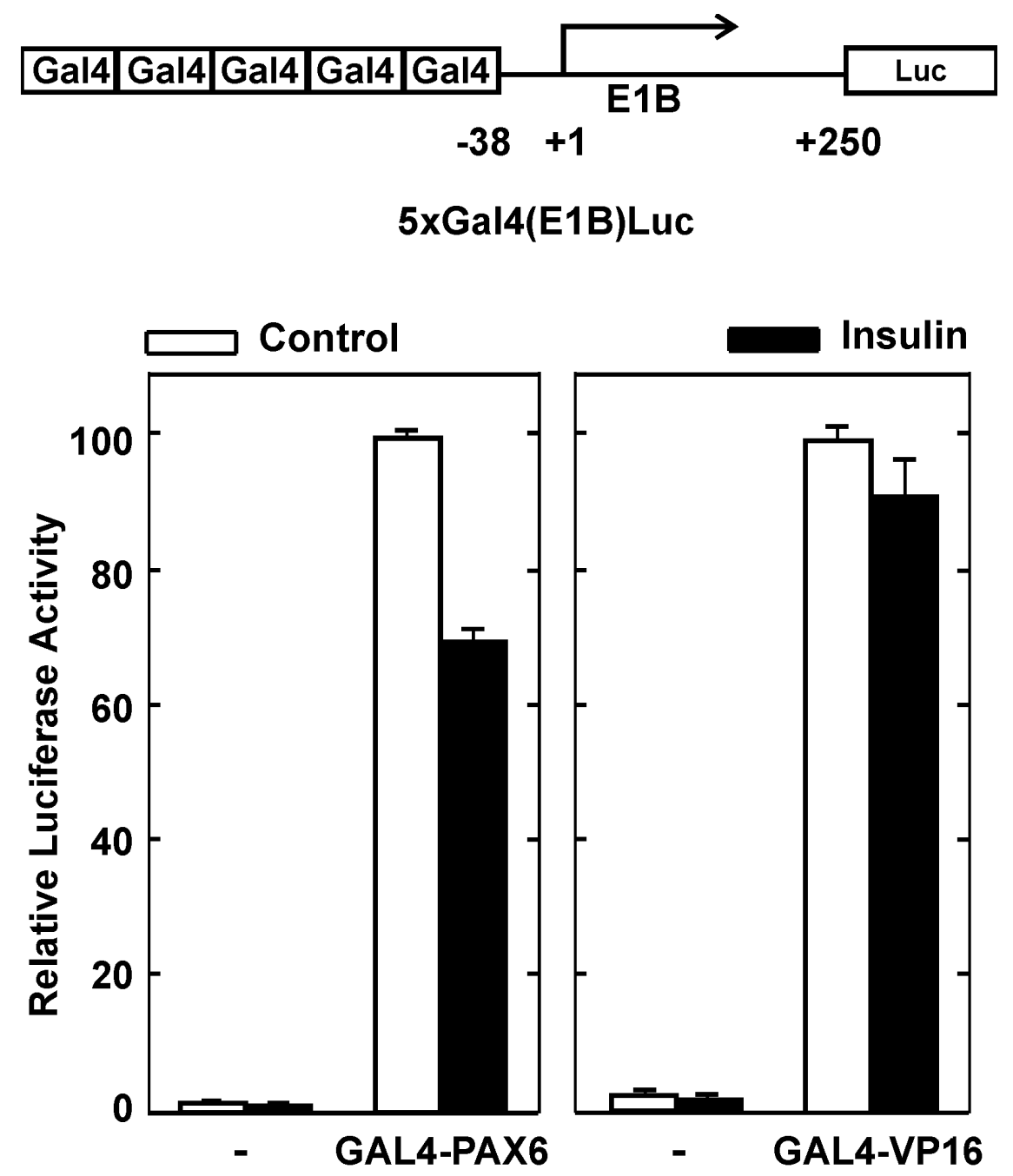

Fig. 6. Inhibition by insulin of Pax6 transcriptional activity as determined using the GAL4 system. Expression vectors encoding GAL4-Pax6 or GAL4-VP16 (1 or $0.5 \mu \mathrm{g} / 6-\mathrm{cm}$ dish, respectively) were transfected into InR1-G9 cells together with the $5 \times$ Gal4(E1B)Luc reporter gene ( $2 \mu \mathrm{g} / 6-\mathrm{cm}$ dish), depicted above, and the cells were treated with insulin (10 $\mathrm{nM}$ ) as indicated. Luciferase activity is expressed as percentage of the mean value, in each experiment, of the activity measured after cotransfection of GAL4-Pax6 or GAL4-VP16 without insulin treatment. Values are means \pm SE of three (GAL4-Pax6) or four (GAL4-VP16) independent experiments, each done in duplicate. Luc, Luciferase; Control, no insulin treatment. 
In this system transcriptional activity of the reporter gene construct, 5xGal4(E1B)Luc, depends on the binding and transactivation achieved by the GAL4-Pax6 fusion protein. As shown in Fig. 6, coexpression of the GAL4-Pax6 fusion protein raised transcriptional activity $68 \pm 1$-fold. Insulin inhibited GAL4-Pax6 transcriptional activity by $30 \%$ (Fig. 6). Furthermore, insulin had no effect on the transcriptional activity conferred by the viral VP16 protein (Fig. 6), which was used as a negative control. VP16 is a strong, viral transcriptional factor is not involved in the regulation of the rat glucagon gene transcription (Berk 1999). Insulin did not inhibit the expression of the GAL4-Pax6 fusion protein as revealed by electrophoretic mobility shift assay (Fig. 7) and Western blotting (Fig. 8).

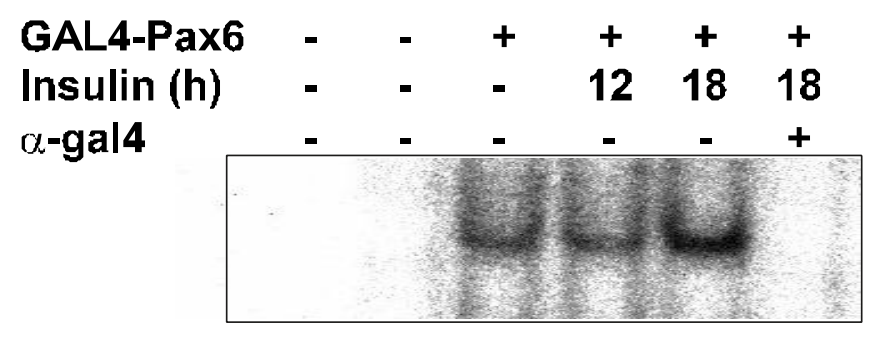

Fig. 7. Lack of inhibition by insulin of GAL4-Pax6 expression as revealed by electrophoretic mobility shift assay. An expression vector encoding GAL4-Pax6 (1 $\mu \mathrm{g} / 6$ $\mathrm{cm}$ dish) was transfected into InR1-G9 cells, and the cells were treated with insulin (10 $\mathrm{nM})$ for 12 or $18 \mathrm{~h}$ or were left untreated. Nuclear extracts were prepared and incubated with a labelled GAL4 DNA binding site as described in "Materials and Methods" (2.27). The retarded band is shown, which is recognised by an antiserum directed against the DNAbinding domain of GAL4 ( $\alpha$-gal4) (Santa Cruz Biotechnology, Heidelberg, Germany). First lane to the left, no nuclear extract added (probe only).

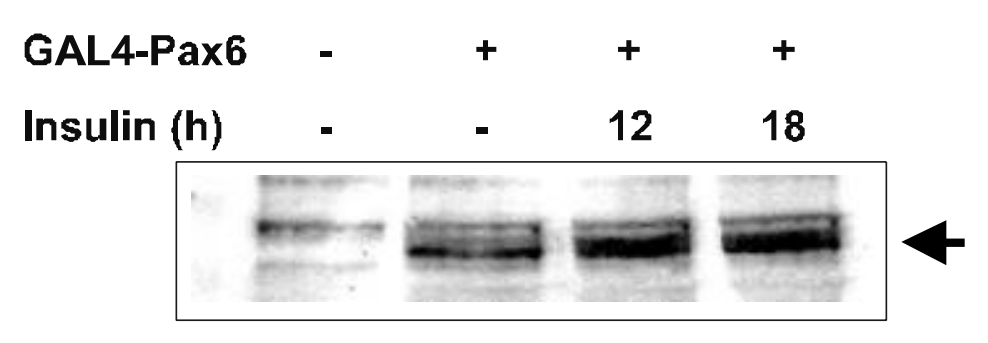

Fig. 8. Lack of inhibition by insulin of GAL4-Pax6 expression as revealed by Western blotting. An expression vector encoding GAL4-Pax6 $(1 \mu \mathrm{g} / 6-\mathrm{cm}$ dish) was transfected into InR1-G9 cells, and the cells were treated with insulin (10 $\mathrm{nM})$ for 12 or $18 \mathrm{~h}$ or were left untreated. Nuclear extracts from InR1-G9 cells were separated by SDS-PAGE and blotted onto nitrocellulose filter. The filter was probed with antiserum directed against the DNAbinding domain of GAL4 ( $\alpha$-gal4, Santa Cruz Biotechnology, Heidelberg, Germany). An arrow indicates a band which is specific for the GAL4-Pax6 protein. 


\subsection{Requirement of Pax6 for inhibition of glucagon gene transcription by insulin in InR1-G9 cells}

\section{Effect of overexpression of the Pax6 paired domain}

To further study the role of Pax6 in the repression of glucagon gene transcription by insulin, a portion of the Pax6 protein (amino acids 1 to 246) was overexpressed, which contains the paired domain (splice variant without exon 5a) but lacks the transactivation domain and most of the homeodomain. This splice variant of the Pax6 paired domain has been shown to bind to the PISCES motif (Beimesche et al.1999), within the G3A and G1 elements of the glucagon gene (Beimesche et al.1999, Knepel et al.1990, Knepel et al.1991). It was assumed that through competition for DNA binding, the overexpression of the Pax6 paired domain can prevent transactivation domain-dependent functions of endogenous Pax6. As a positive control the construct $4 \times G 3 A(T 81) L u c$ was included in this experiment, since it is driven by a synthetic minienhancer built of four copies of the Pax6 binding site within G3A, and its activity entirely depends on Pax6 function. As shown in Fig. 9, the expression of the Pax6 paired domain decreased basal activity of the construct 4xG3A(T81)Luc by $90 \%$ and completely abolished negative regulation by insulin. After transfection of -350 GluLuc, the overexpression of the Pax6 paired domain decreased basal glucagon gene transcription by $70 \%$ (Fig. 9). Whereas insulin inhibited glucagon gene transcription in the controls by $65 \%$, it failed to do so in the presence of the Pax6 paired domain (Fig. 9). It has been shown in another study (Grzeskowiak 2000) that four copies of the G2 element confer insulin responsiveness to the insulin-nonresponsive truncated glucagon promoter (-136GluLuc). The G2 element does not contain a Pax6 binding site, although the nonresponsive, truncated glucagon promoter does (PISCES within the G1element) (Beimesche et al.1999, Knepel et al.1990, Knepel et al.1991b, Andersen et al.1999). To examine the role of Pax6 under this condition, the effect of expression of the Pax6 paired domain on G2driven transcriptional activity was studied. As shown in Fig. 9, the expression of the Pax6 paired domain did not alter basal transcriptional activity of the G2 element in front of the truncated glucagon promoter. However, the expression of the Pax6 paired domain completely abolished the inhibition of transcription by insulin (Fig. 9). 
Effect of mutations of the Pax6-binding sites within the glucagon promoter

As a second approach to study the role of Pax6 in the repression of glucagon gene transcription by insulin, the Pax6 binding sites (PISCES motifs) of the glucagon promoter within G3A, G1 or both were changed and thereby mutated into binding sites of the yeast transcription factor GAL4 (Fig. 10).
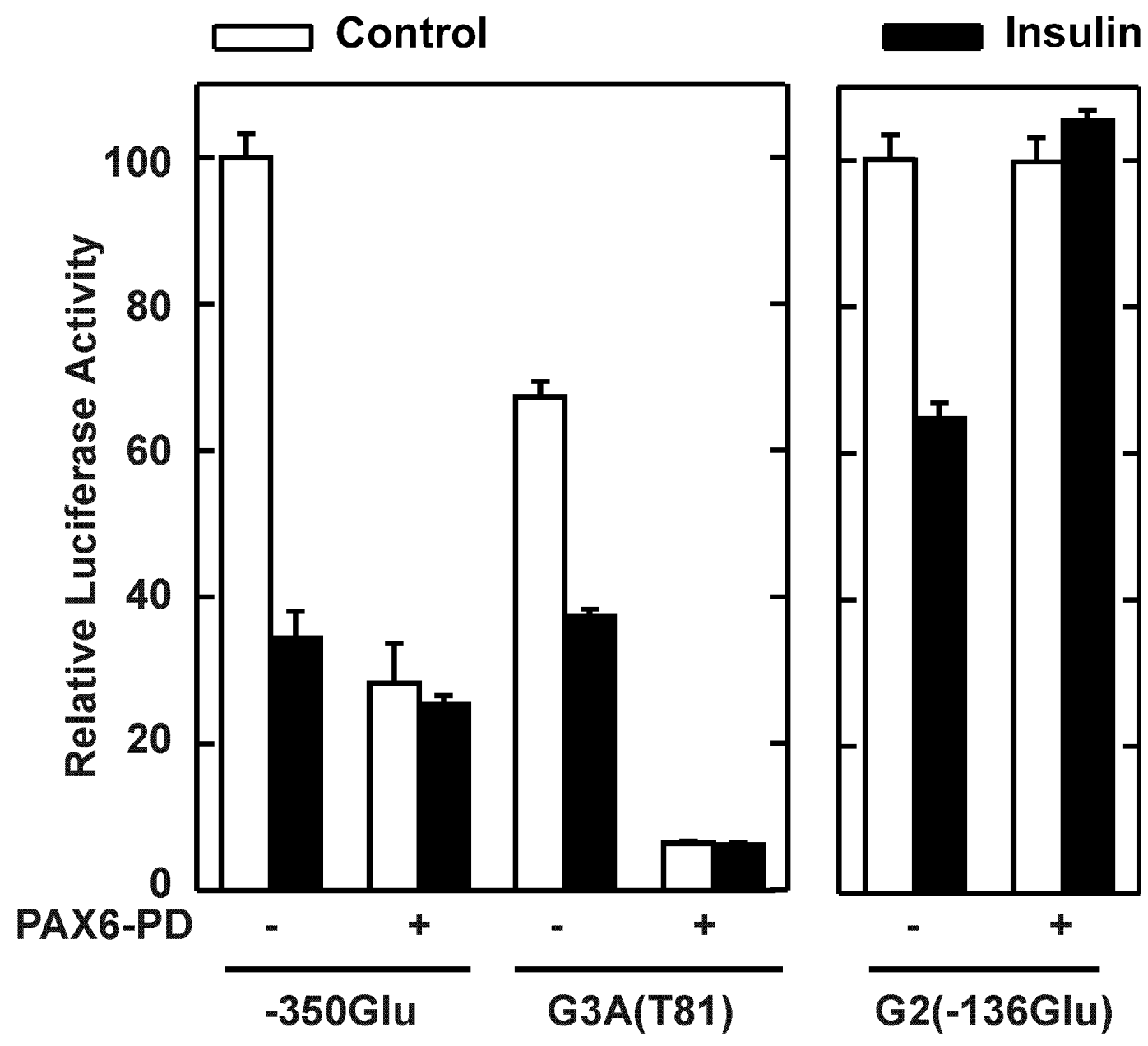

FIG. 9. Effect of overexpression of the Pax6 paired domain on insulin responsiveness. An expression vector encoding the Pax6 paired domain (Pax6-PD, $5 \mu \mathrm{g} / 6-\mathrm{cm}$ dish) was transfected into InR1-G9 cells together with -350GluLuc, 4xG3A(T81)Luc or 4xG2(136)GluLuc reporter genes $(0.5 \mu \mathrm{g} / 6-\mathrm{cm}$ dish), and the cells were treated with insulin (10 $\mathrm{nM})$ or left untreated (control). Luciferase activity is expressed as percentage of the mean value, in each experiment, of the activity measured after transfection of -350GluLuc or 4xG2(136Glu)Luc (without insulin and Pax6-PD). Values are means \pm SE of three independent experiments, each done in duplicate. 

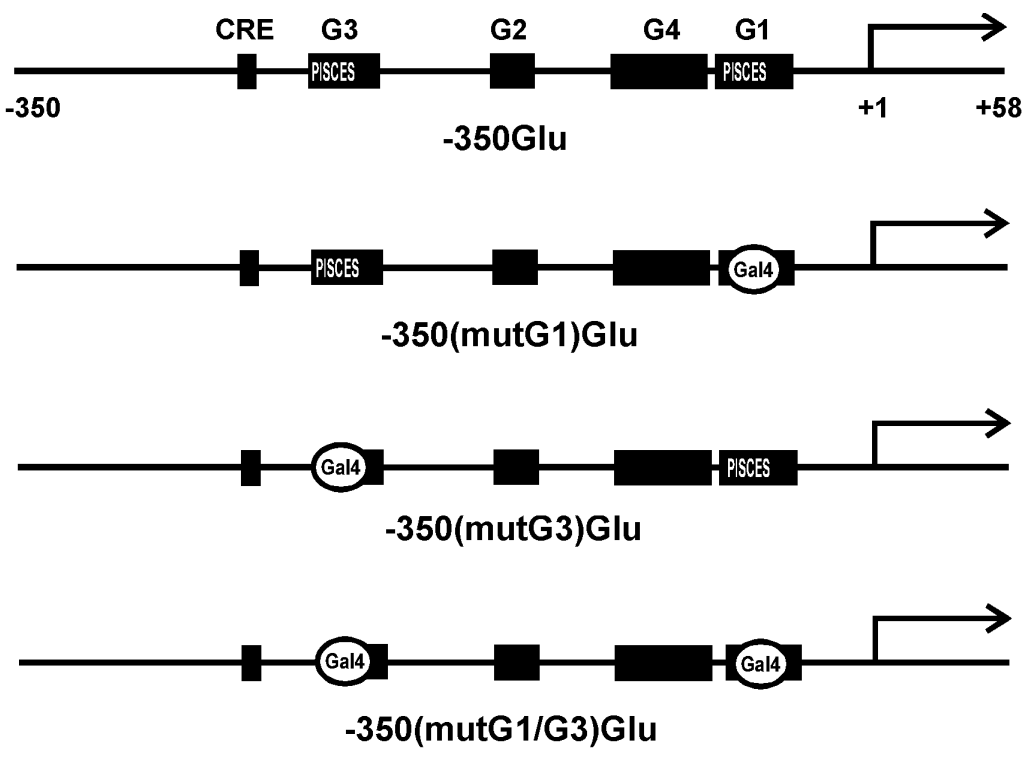

Fig. 10. Schematic representation of the wild-type and mutated glucagon reporter genes. Pax6 binds to the PISCES motifs (pancreatic islet cell-specific enhancer sequence) within G1 and G3. Bases including the PISCES motif within G1, G3 or G1 plus G3 were mutated into GAL4 binding sites.

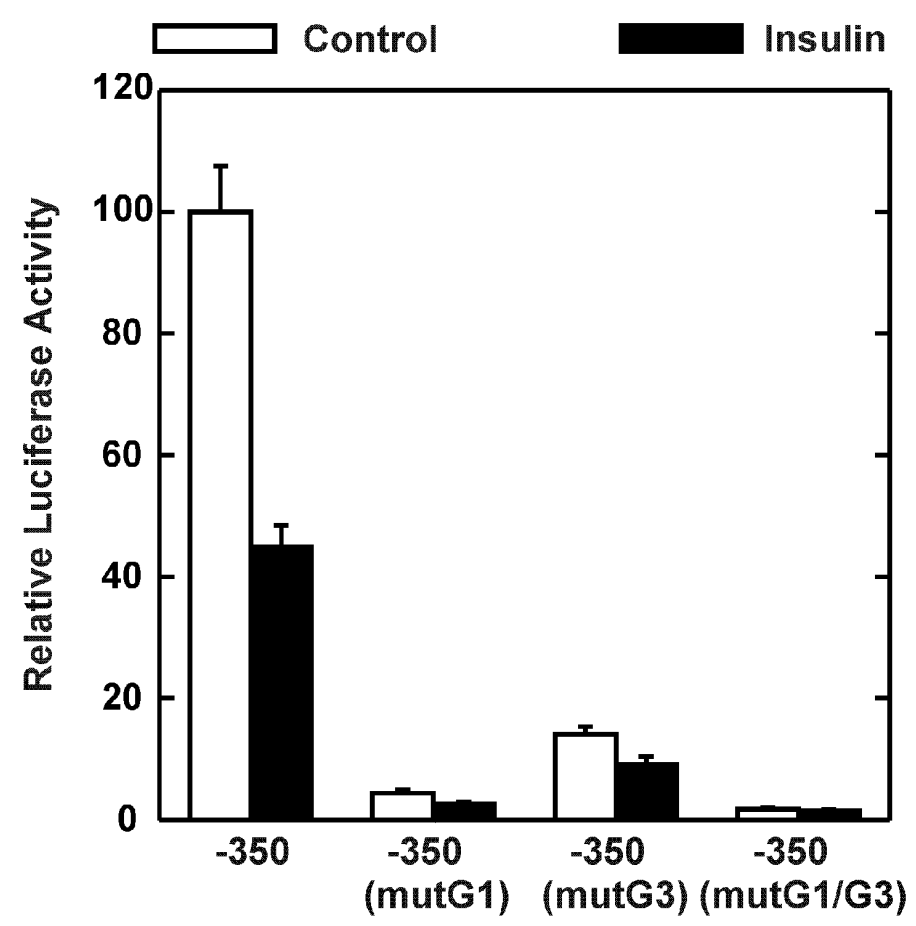

Fig. 11. Basal activity and insulin responsiveness of the mutant glucagon reporter genes. Plasmids -350GluLuc, -350 (mutG1)GluLuc, -350 (mutG3)GluLuc, and -350 (mutG1/G3)GluLuc were transfected into InR1-G9 cells, and the cells were treated with insulin (10 $\mathrm{nM}$ ) or left untreated (control). Luciferase activity is expressed as percentage of the mean value, in each experiment, of the activity measured in the -350GluLuc controls. Values are means \pm SE of three independent experiments, each done in duplicate. 
As shown in Fig. 11, the mutation of the Pax6 binding sites within G3, G1, and G3 plus G1 decreased basal transcriptional activity of the glucagon promoter to 14.1 , 4.4, and $1.8 \%$ of wild type, respectively, confirming that Pax6 is important for basal glucagon promoter activity. The remaining low transcriptional activities of the mutant glucagon promoters were not inhibited by insulin (Fig. 11).

Restoration of the transcriptional activity and insulin responsiveness of the mutated glucagon promoter by overexpression of GAL4-Pax6

Due to potentially overlapping binding sites, the mutation of the PISCES motifs may not only abolish Pax6 binding but also affect the binding of additional transcription factors like cdx2/3 and brain-4 within G1 (Andersen et al.1999, Ritz-Laser et al.1999, Hussain et al.1997, Jin and Drucker 1996).

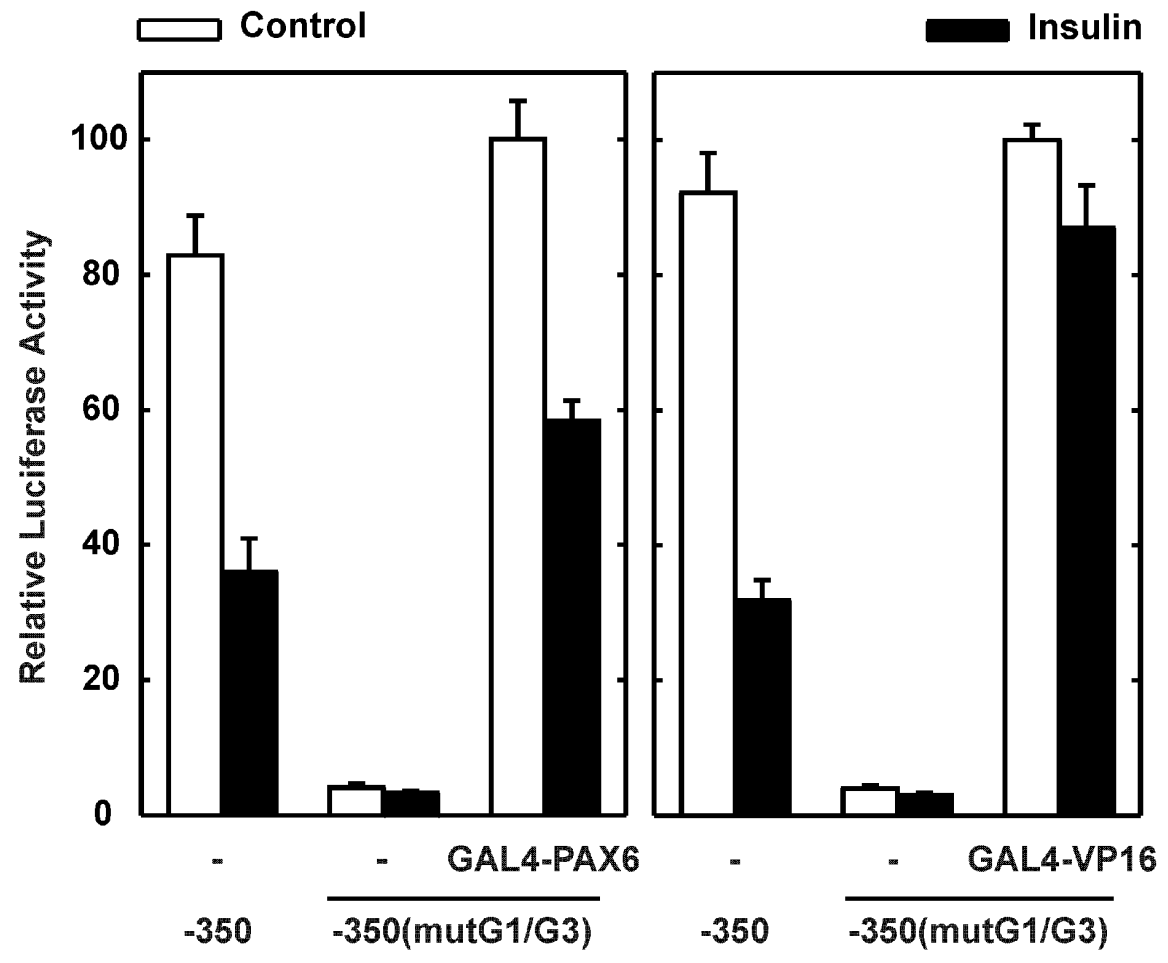

FIG. 12. Overexpression of GAL4-Pax6 restores basal activity and insulin responsiveness of glucagon gene transcription after mutation of the Pax6 binding sites into GAL4 binding sites. Expression vectors encoding GAL4-Pax6 or GAL4-VP16 (50 or $15 \mathrm{ng} / 6-\mathrm{cm}$ dish, respectively) were transfected into InR1-G9 cells together with the 350(mutG1/G3)GluLuc reporter gene, and the cells were treated with insulin (10 nM) or left untreated (control); for comparison, the wild-type -350GluLuc construct was also transfected $(-350)$. Luciferase activity is expressed as percentage of the mean value, in each experiment, of the activity measured in the GAL4-Pax6 or GAL4-VP16 controls. Values are means \pm SE of three independent experiments, each performed in duplicate. 
It was therefore examined whether basal activity and insulin responsiveness of the glucagon promoter can be restored by Pax6 recruited to the double mutant glucagon promoter through the GAL4 binding sites. When an expression vector encoding a GAL4-Pax6 fusion protein was transfected together with -350(mutG1/G3)GluLuc, basal transcriptional activity of the doubly mutated glucagon promoter was restored to a level similar to that of the wild-type promoter (Fig. 12). The expression of GAL4Pax6 also conferred insulin responsiveness (Fig. 12). After cotransfection of 350(mutG1/G3)GluLuc and the GAL4-Pax6 expression vector, insulin inhibited transcription by $43 \pm 1 \%$; this is similar to the inhibition by insulin of the wild-type glucagon promoter activity (56 $\pm 3 \%$ ) (Fig. 12). This effect of GAL4-Pax6 seems to be specific and also not secondary to the restoration of basal activity, because the expression of GAL4-VP16 restored basal activity of the doubly mutated glucagon promoter, which was however not inhibited by insulin (Fig. 12).

\subsection{DNA-binding and electro-phoretic mobility of PAX6 proteins after insulin treatment in InR1-G9 cells}

Insulin-induced signalling pathways have been shown to regulate the phosphorylation and subcellular localisation of transcription factors like FKHR (Rena et al.1999, Tang et al.1999). To study if similar mechanisms might regulate Pax6dependent transcriptional activity of the glucagon gene, experiments were performed investigating the DNA-binding and protein levels of Pax6 after insulin treatment in the InR1-G9 cells.

\section{Effect of insulin treatment on Pax6 DNA binding as revealed by EMSA}

Negative regulation by insulin of Pax6-dependent transcriptional activity might be explained by changing DNA-binding properties upon insulin stimulation. To study this possibility electro-phoretic mobility shift assay (EMSA) was performed.

Radioctively labelled G3 oligonucleotide was used as a probe, which was shown previously to bind Pax6 (through domain A) (Sander et al.1997). Nuclear proteins from the InR1-G9 cells (two different preparations) showed a binding of Pax6 to the G3 probe (Fig. 13), which was not changed by the insulin treatment (30 and 60 minutes). Specificity of the binding was assessed by using an antiserum directed 
against the paired domain of Pax6, which abolished Pax6 DNA binding (the arrow in Fig.13). As a positive control bacterially expressed, GST-fused Pax6 paired domain (PD) was used which is visible as a prominent band migrating below Pax6-specific band (GST-fused PD is smaller and migrates faster than full length Pax6). These results show that Pax6 DNA-binding properties are not changed upon insulin treatment as detected in this EMSA.
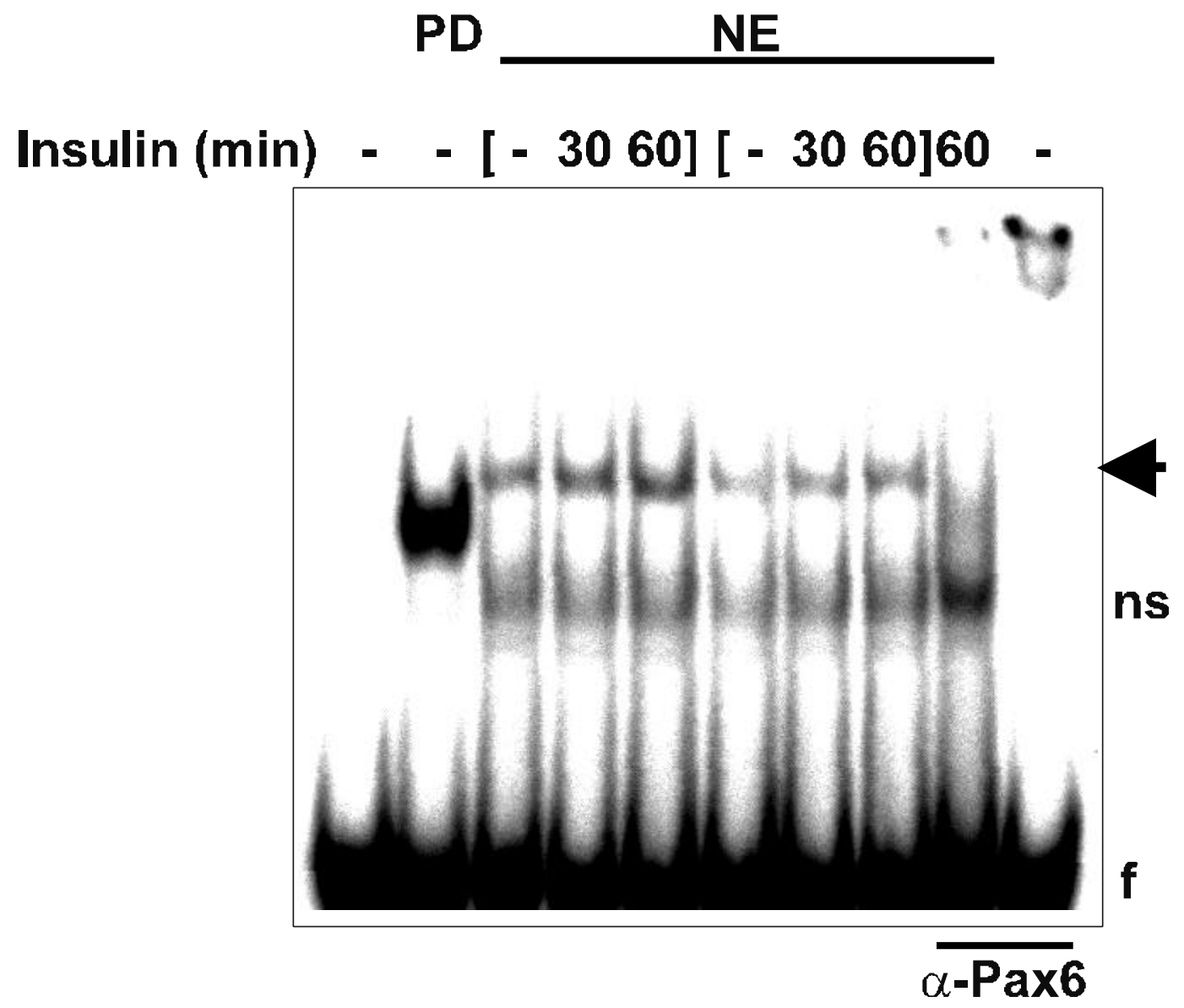

Fig. 13. Effect of insulin treatment on Pax6 DNA binding. Radioactively labelled G3 oligonucleotide was incubated with nuclear extracts from InR1-G9 cells treated with insulin for the time indicated (minutes) or left untreated (two independent experiments shown in square brackets). Pax6-specific complexes are indicated by arrow as the binding is abolished by anti-Pax6 serum ( $\alpha$-Pax6) treatment. Bacterially expressed Pax6 paired domain (PD) was included $(2 \mu \mathrm{g})$ as a binding positive control. First lane to the left - probe only, last lane to the right - probe with $\alpha$-Pax6 only. NE - nuclear extract, ns - nonspecific band, $f$ - free probe. 
Effect of insulin on Western blot analysis of Pax6 protein after insulin treatment Insulin may exert its action on gene transcription through changes in the expression level of a given transcription factor protein or, as it was shown in case of FKHR (Tang et al.1999; Rena et al.1999) or AFX (Geert et al.1999), by changes in the phosphorylation state. Either different level of protein expression or postranslational modifications in phosporylation state may be revealed using Western blot analysis. Changes in the band intensity can reflect different protein expression and different migration properties might be due to differences in the state of phosphorylation after insulin treatment. Results from Western blot analysis using Pax6-specific antibodies are shown in the Fig. 14. Nuclear extracts were used from InR1-G9 cells treated with insulin for 8, 20 and 60 minutes or without insulin. The expression level of Pax6 protein was not changed by insulin treatment. Also no changes in the mobility of Pax6 protein could be detected.

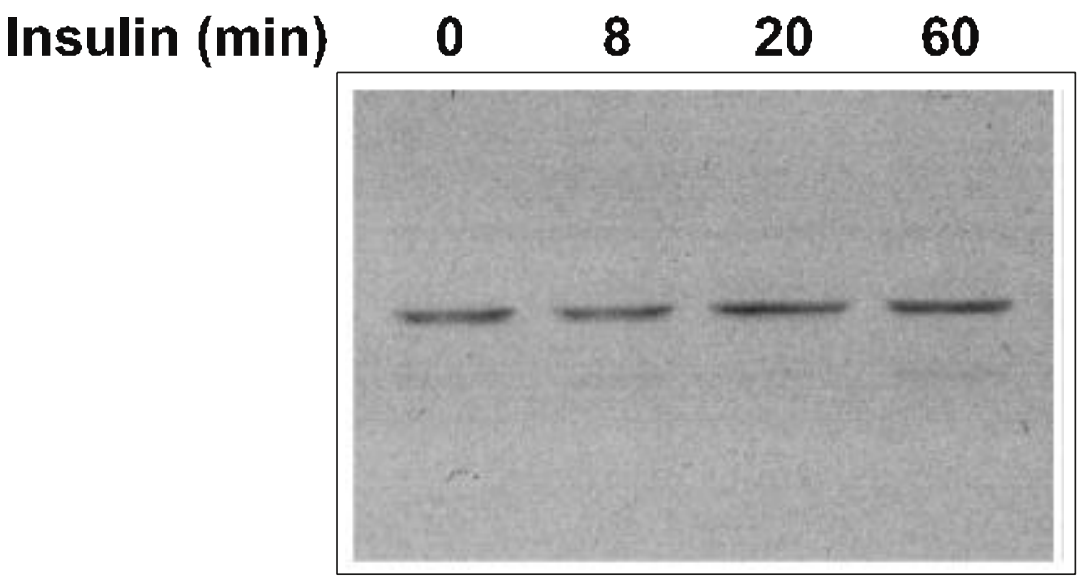

Fig. 14. Western blot analysis of Pax6 after insulin treatment. Nuclear extracts from InR1-G9 cells treated with insulin for the indicated time (minutes) were subject to Western blot analysis. Pax6-specific antibody ( $\alpha-P a x 6$ [C-20] goat polyclonal IgG, Santa Cruz Biotechnology, Heidelberg) was used to detect Pax6 proteins.

\subsection{Effect of a mutation of extracellular signal-regulated kinase (ERK) and p38 kinase sites within the Pax6 transactivation domain on the regulation by insulin.}

There is evidence that the transactivation domain (TAD) of Pax6 is a substrate both in vitro and in vivo for extracellular signal-regulated kinase (ERK) and p38 kinase 
(Mikkola et al. 1999). Three sites were described $\left(\mathrm{Thr}^{323}, \mathrm{Ser}^{376}\right.$ and $\mathrm{Ser}^{413}$ ), which after phosphorylation by ERK or p38 kinase stimulated transactivating properties of Pax6. To test whether these kinases are involved in the regulation of Pax6dependent transcriptional activity by insulin, the GAL4 system was used. The GAL4 DNA-binding domain was fused to zebrafish Pax6 TAD where all three ERK/p38 phosphorylation sites were mutated (Mikkola et al. 1999). When cotransfected together with the mutated glucagon reporter gene, in which both Pax6 binding sites within G1 and G3 had been mutated into GAL4 binding sites, this ERK/p38insensitive mutant (GAL4-TADm3) conferred strong transcriptional activity which was three fold higher as compared to the activity conferred by the wild type TAD (GAL4TADwt).

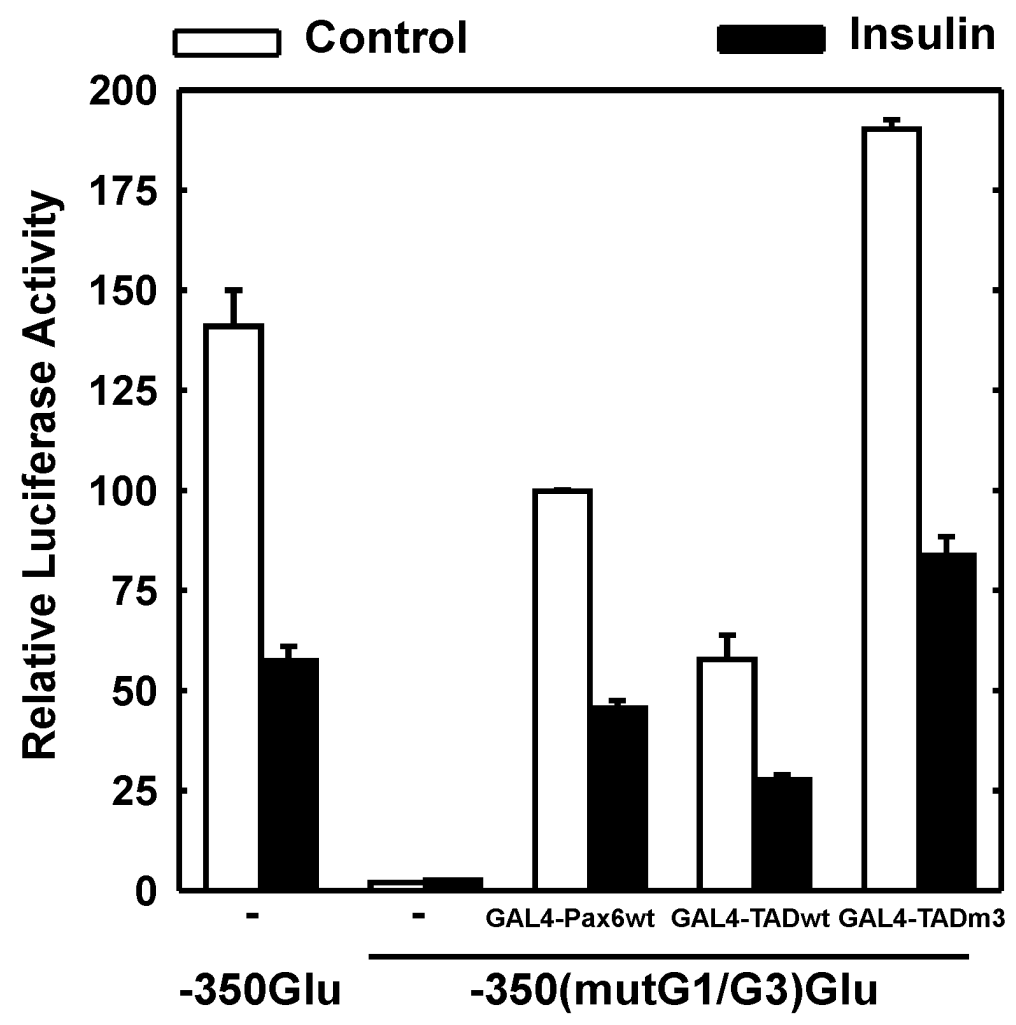

Fig. 15. Mutation of p38/ERK phosphorylation sites within Pax6 transactivation domain does not abolish negative regulation by insulin. InR1-G9 cells were transfected with 350 (mutG1/G3)GluLuc reporter gene ( $2 \mu \mathrm{g} / 6-\mathrm{cm}$ dish) together with expression vectors (each $100 \mathrm{ng} / 6-\mathrm{cm}$ dish) encoding following proteins: GAL4-TADm3 (Pax6 TAD with mutated three p38 kinase/ERK phosphorylation sites), GAL4-TADwt (wild type Pax6 transactivation domain from zebrafish) and GAL4-Pax6 (full length, wild type Pax6 from mouse). The cells were treated with insulin $(10 \mathrm{nM})$ or left untreated (control). Luciferase activity is expressed as percentage of the mean value, in each experiment, of the activity of -350GluLuc (without insulin). Values are means \pm SE of three independent experiments, each done in duplicate. 
The activity of the triple mutant was inhibited by insulin by 55\% (Fig. 15). Similar level of inhibition was also seen in case of the wild type TAD and full length, wild type Pax6 (GAL4-Pax6wt) constructs, 50 and 54\% respectively (Fig. 15).

\subsection{Effect of insulin on CBP-mediated transcriptional activity}

Effect of insulin on GAL4-CBP activity in the context of the glucagon promoter but not in the context of viral E1B promoter

Evidence suggests that the p300/CBP proteins may interact with and function as coactivators of Pax6 (Hussain and Habener 1999). To test the hypothesis that CBP, like Pax6, can confer insulin responsiveness to the glucagon promoter, full length CBP was fused to the GAL4 DNA-binding domain.

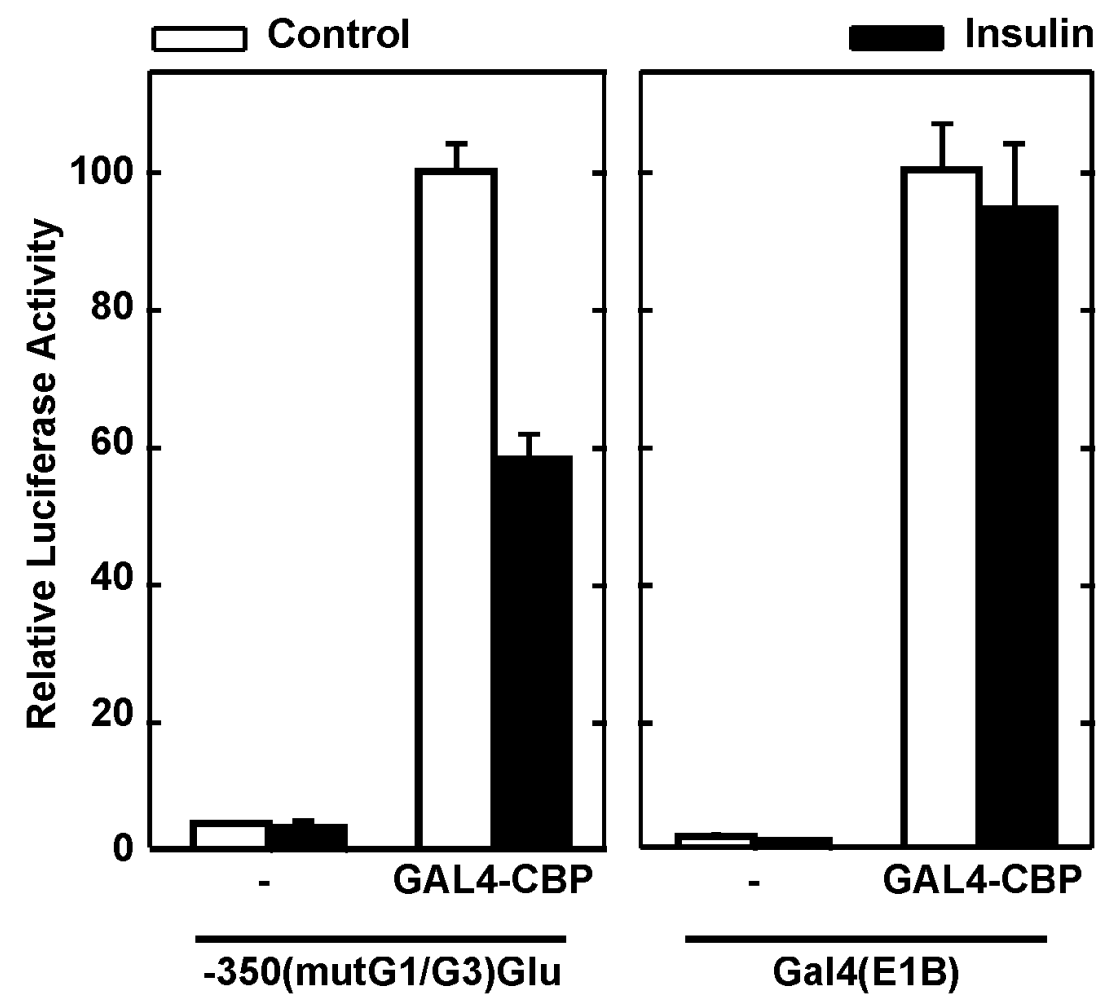

Fig. 16. Inhibition by insulin of GAL4-CBP activity in the context of the glucagon promoter. An expression vector encoding GAL4-CBP (pGAL-CBP8, $2 \mu \mathrm{g} / 6-\mathrm{cm}$ dish) was transfected into InR1-G9 cells together with -350 (mutG1/G3)GluLuc or $5 \times$ Gal4(E1B)Luc reporter gene, and the cells were treated with insulin $(10 \mathrm{nM})$ or left untreated (control). Luciferase activity is expressed as percentage of the mean value, in each experiment, of the activity measured in the respective GAL4-CBP control. Values are means \pm SE of three independent experiments, each done in duplicate. 
When cotransfected together with the mutated glucagon reporter gene, in which both Pax6 binding sites within G1 and G3 had been mutated into GAL4 binding sites (350(mutG1/G3)GluLuc), GAL4-CBP conferred strong basal activity which was inhibited by insulin by $40 \%$ (Fig. 16). In contrast, when cotransfected with a reporter construct, in which multiple GAL4 binding sites had been placed in front of the truncated viral E1B promoter (5xGal4(E1B)Luc), GAL4-CBP conferred transcriptional activity which was however not inhibited by insulin (Fig. 16).

Effect of insulin on transcriptional activity conferred by $N$-terminal and $C$-terminal part of $C B P$.

CBP is a large, multimodular protein with many domains interacting with numerous cofactors and transcriptional factors (Fig. 17) (Glass and Rosenfeld 2000, Giordano and Avantagiatti 1999). In order to further characterise the role of CBP in the insulin responsiveness of the glucagon promoter, and to localise any particular domain required and/or sufficient to confer negative regulation by insulin, several constructs were used where the GAL4 DNA-binding domain was fused with different parts of CBP.

As the first approach three constructs were used where the GAL4 DNA binding domain was fused to N-terminal (amino acids 1-451), middle (amino acids 10611891) and C-terminal (amino acids 1892-2441) part of CBP (Fig. 17 and 18).

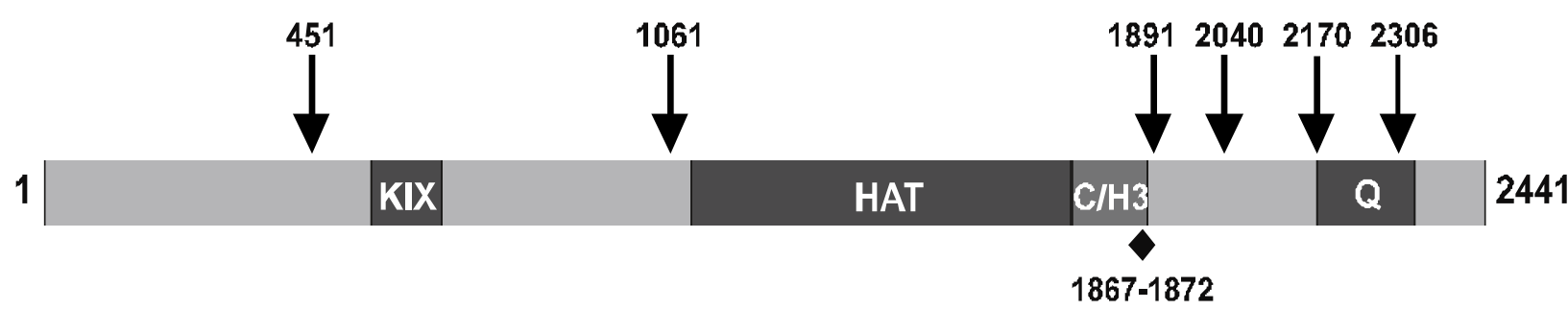

Fig. 17. Schematic representation of the CBP protein. Main functional domains and amino acids positions are indicated. C/H3: cystine/histidine-rich, HAT: histone acetyltransferase, KIX: CREB-interacting domain, Q: glutamine-rich, cofactor-interacting domain. A black diamond indicates a consensus PKB phosphorylation site: RRRMAT (amino acid positions shown). 

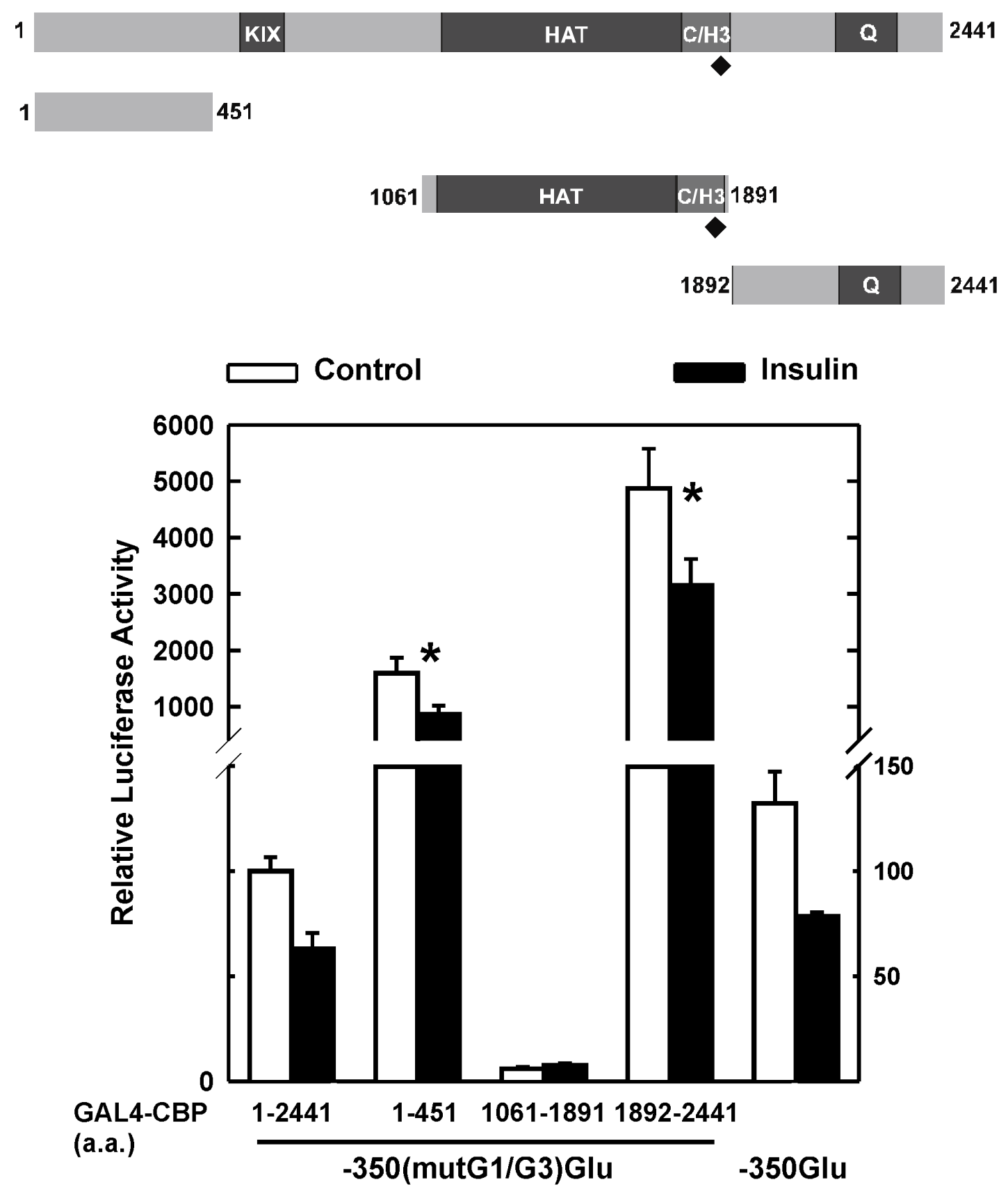

Fig. 18. Insulin inhibition of transcriptional activity conferred by the $\mathrm{N}$ - and $\mathrm{C}$-terminal parts of CBP. Expression vectors encoding GAL4-CBP fusion proteins (parts of CBP depicted above the graph, see also Fig. 17) were transfected $(2 \mu \mathrm{g} / 6-\mathrm{cm}$ dish) into InR1-G9 cells together with -350 (mutG1/G3)GluLuc reporter gene, and the cells were treated with insulin $(10 \mathrm{nM})$ or left untreated (control). Luciferase activity is expressed as percentage of the mean value, in each experiment, of the activity of the GAL4-CBP (1-2441) without insulin. Values are means \pm SE of three independent experiments, each done in duplicate. $\mathrm{C} / \mathrm{H} 3$ : cystine/histidine-rich, HAT: histone acetyltransferase, KIX: CREB-interacting domain, Q: glutamine-rich, cofactor-interacting domain. A black diamond indicates a consensus PKB phosphorylation site. ${ }^{*} P<0.005$ (Student's $t$-test). 
When cotransfected together with the mutated glucagon reporter gene, in which both Pax6 binding sites within G1 and G3 had been mutated into GAL4 binding sites (350(mutG1/G3)GluLuc), GAL4-CBP constructs containing N- and C-terminal parts of CBP conferred strong basal transcriptional activity which was inhibited by insulin by $46 \%$ and $36 \%$ respectively (Fig. 18). Similarly full length CBP conferred inhibition by $43 \%$, which is consistent with previous findings (see above). In contrast construct containing the middle part of CBP conferred relatively low transcriptional activity which was not inhibited by insulin whatsoever (Fig. 18). The positive control (350 GluLuc) was inhibited by insulin by $48 \%$.

Mapping the insulin responsive domain within the $C$-terminal part of $C B P$.

Further mapping of insulin responsiveness was focused on the C-terminal part of $\mathrm{CBP}$, which was subject to several $\mathrm{C}$-, $\mathrm{N}$-terminal and internal deletions. These deletion constructs were fused with the GAL4 DNA binding domain and cotransfected with the doubly mutated glucagon reporter gene.

The whole C-terminal part of CBP containing amino acids 1678 to 2441 conferred basal transcriptional activity which was about $30 \%$ of the activity of the wild type glucagon promoter and was inhibited by insulin by $42 \pm 3 \%(n=8)$. N-terminal deletions (constructs 1880-2441 and 2040-2441) markedly raised the transriptional activity (16 and 10 -fold respectively), which was also inhibited by insulin $(32 \pm 2 \%$ and $41 \pm 2 \%$ respectively). Deleted regions contain the $\mathrm{C} / \mathrm{H} 3$ domain and part of the HAT domain. Further N-terminal deletion of amino acids 1678-2171 and 1678-2306 (constructs 2171-2441 and 2306-2441) resulted in a dramatic decrease of the transcriptional activity and abolishment of the insulin inhibition.

Noteworthy, the construct containing amino acids 2040-2170 (C-terminal deletion of the region 2170-2441), conferred a transcriptional activity comparable to the whole C-terminal part of CBP. This activity was inhibited by insulin by $49 \pm 3 \%(n=6)$, which is also similar to the level observed for the whole C-termianl part of CBP or the wild type glucagon promoter. Interestingly, internal deletion of the region between amino acids 2040-2170 (construct 1678-2441 ${ }^{\Delta 2040-2170}$ ) markedly reduced the transcriptional activity to about $6 \%$ of the activity conferred by the whole C-terminal part (construct 1678-2441). 


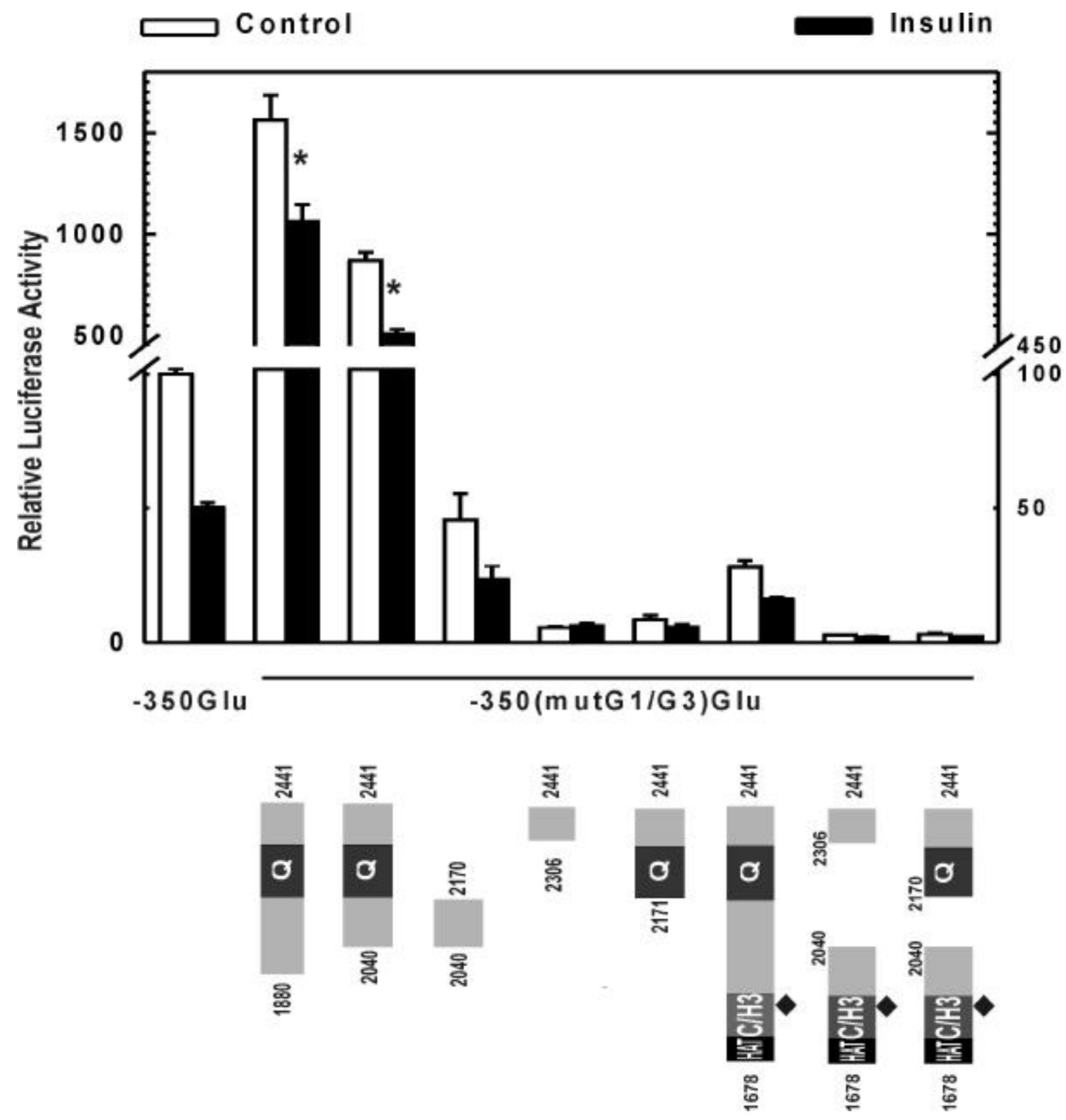

Fig. 19. Mapping the insulin responsive domain within the C-terminal part of CBP. Expression vectors encoding GAL4-CBP fusion proteins $(2 \mu \mathrm{g} / 6-\mathrm{cm}$ dish) were transfected into InR1-G9 cells together with -350 (mutG1/G3)GluLuc reporter gene. The GAL4-CBP constructs are schematically depicted below the graph with indicated important functional domains and amino acid positions. After transfection InR1-G9 cells were treated with insulin $(10 \mathrm{nM})$ or left untreated (control). Luciferase activity is expressed as percentage of the mean value, in each experiment, of the activity of -350GluLuc (without insulin). Values are means \pm SE of three independent experiments, each done in duplicate. A black diamond indicates a consensus PKB phosphorylation site. $\mathrm{C} / \mathrm{H} 3$ : cystine/histidine-rich, HAT: histone acetyltransferase, Q: glutamine-rich, cofactor-interacting domain (see also Fig. 17). ${ }^{*} P<0.005$ (Student's $t$-test). 
Effect of overexpression of constitutively active protein kinase $B$ (myrPKB) on the activity of the glucagon promoter and activity conferred by CBP

To test whether PKB can regulate the CBP-mediated activity a constitutively active form of PKB was overexpressed, myrPKB. The overexpression of myrPKB was assumed to mimic the insulin effect. In the myrPKB construct a myristolyation signal is added which directs PKB to the plasma membrane where it is activated by upstream kinases - PDK1 and PDK2 (Andjelkovic et al.1997).

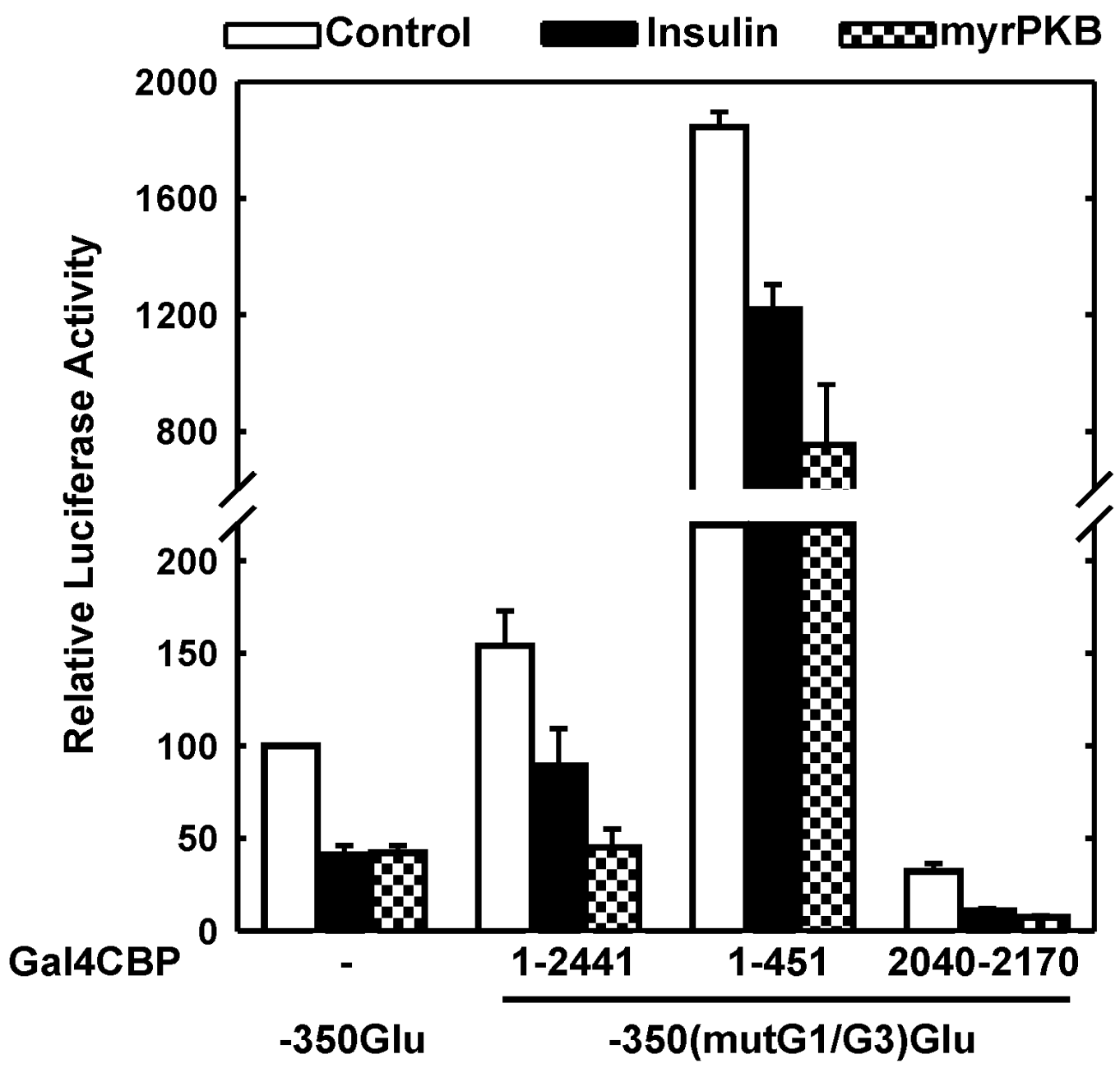

Fig. 20. Inhibition of GAL4-CBP activity by myrPKB overexpression. Expression vectors encoding GAL4-CBP fusion proteins (amino acid number indicated) were transfected $(2 \mu \mathrm{g} / 6$ $\mathrm{cm}$ dish) into InR1-G9 cells together with -350 (mutG1/G3)GluLuc. When indicated also constitutively active PKB expression vector $(1 \mu \mathrm{g} / 6-\mathrm{cm}$ dish) - myrPKB was transfected. The cells were treated with insulin (when indicated) $(10 \mathrm{nM})$ or left untreated (control). Luciferase activity is expressed as percentage of the mean value, in each experiment, of the activity of 350GluLuc (without insulin and myrPKB). Values are means \pm SE of three independent experiments, each done in duplicate. 
Together with the mutated glucagon reporter gene -350(mutG1/G3)Glu, constructs were cotransfected where the GAL4 DNA binding domain was fused with full length (1-2441), N-terminal (1-451) and smallest, insulin responsive, C-terminal part of CBP (2040-2170) (Fig .20). As a control -350GluLuc was also transfected. The overexpression of myrPKB inhibited transcriptional activity conferred by all three GAL4-CBP constructs by $72 \pm 4 \% \quad(n=6), 59 \pm 11 \% \quad(n=6)$, and $77 \pm 2 \% \quad(n=6)$ respectively (Fig. 20). Also the activity of the glucagon promoter was inhibited by the overexpression of myrPKB $(58 \pm 4 \%, n=6)$. 


\section{DISCUSSION}

Insulin inhibits glucagon secretion and gene transcription. This important aspect of body's glucose homeostasis has a clinical significance in diabetes mellitus, which apart from insulin deficiency, is characterised by high glucagon levels secondarily contributing to hyperglycaemia (Unger and Orci 1981, Lefebvre 1995). However, despite this clinical importance as a potential target for treating diabetes mellitus, the molecular mechanism of inhibition of glucagon gene transcription by insulin is poorly understood.

It has been shown that 350 base pairs of the glucagon gene 5'-flanking region are sufficient for negative regulation by insulin in the glucagon-producing pancreatic islet cell line InR1-G9 (Philippe 1989). It was also hypothesised that the G3 element may function as an insulin response element (IRE) of the glucagon gene. However, recent deletional analysis of the -350 region (Grzeskowiak et al. 2000) failed to identify any single element required and sufficient to confer the insulin responsiveness. On the contrary it was speculated that the effect of insulin depends rather on the presence of both proximal promoter elements and more distal enhancer-like elements (Grzeskowiak et al. 2000). The present study expands this hypothesis by showing a critical role of the paired-domain transcription factor Pax6 in this interaction. It also demonstrates that the Pax6-interacting coactivator CBP is capable to confer negative regulation by insulin in glucagon promoter context-specific manner.

\subsection{The involvement of Pax6 in the regulation of glucagon gene transcription by insulin.}

The results of the present study confirm the expression of Pax6 in adult pancreatic islets (Turque et al. 1994, Sander et al. 1997). They also indicate that the transcripts in the adult islets are fully consistent with the known Pax6 cDNA, with and without an alternatively spliced exon 5a (Walther and Gruss 1994). One of the two Pax6 splice variants expressed in mature pancreatic islets and islet cell lines (this study, 
Beimesche et al. 1999) binds through the PISCES motif to an enhancer-like element, G3A, and, possibly together with cdx2/3 or brain-4 (Hussain et al. 1997, Jin and Drucker 1996), to a proximal promoter element (G1) of the glucagon gene (Beimesche et al. 1999, Knepel et al. 1990, Sander et al. 1997, Andersen et al. 1999, Knepel et al. 1991, Ritz-Laser et al. 1999). The binding of Pax6 to both elements is critical for basal activity and insulin responsiveness. The mere presence of a single Pax6 binding site is not sufficient to confer the insulin response since reporter genes containing the truncated glucagon promoter (-136GluLuc) or the 3'-deleted glucagon promoter fragment from -350 to -150 include a Pax6 binding site but are not negatively regulated by insulin (Grzeskowiak et al. 2000).

However, Pax6 seems to play a critical role for the glucagon gene response to insulin in pancreatic islet cell line InR1-G9. This glucagon-producing cell line shows many characteristics of the mature A-cell and is regulated by insulin (Takaki et al. 1986) - it is therefore a useful model for studies of gene regulation by insulin.

This study provides evidence that Pax6 activity in InR1-G9 cells can be inhibited by insulin. Firstly, the activity of an artificial minienhancer consisting of synergizing Pax6 binding sites (G3A) in front of a heterologous promoter (TK) was inhibited by insulin. Secondly, insulin inhibited the GAL4-Pax6-mediated activity of the reporter gene construct under control of multiple Gal4 sites and minimal E1B promoter. This effect specifically depends on Pax6 because insulin had no effect on the transcriptional activity conferred by the viral VP16 transcription factor; furthermore insulin did not inhibit the expression of the GAL4-Pax6 fusion protein as revealed by electrophoretic mobility shift assay and Western blotting. Thus, although the extent of inhibition of GAL4-Pax6 transcriptional activity was less than that of -350 GluLuc, these results indicate that Pax6 is capable to confer insulin responsiveness in InR1-G9 cells.

The present study also provides evidence that Pax6 is required for the repression of the glucagon gene transcription by insulin. Coexpression of a portion of the Pax6 protein (amino acids 1 to 246) that contains the paired domain (without exon 5a) but lacks the transactivation domain and most of the homeodomain, dramatically decreased basal activity and completely abolished insulin inhibition of the construct driven by four copies of the Pax6-binding site, 4XG3A(T81)Luc. This suggests that the expression of the Pax6 paired domain efficiently prevents Pax 6 functions. The 
expression of the Pax6 paired domain also decreased basal transcription levels and insulin inhibition of the glucagon gene (-350GluLuc), consistent with the assumption that Pax6 is required for repression of glucagon gene transcription by insulin. Furthermore, the overexpression of the Pax6 paired domain completely abolished the inhibition of transcription by insulin of the $\mathrm{G} 2$ element in front of the truncated glucagon promoter, G2(-136Glu), without altering its basal transcriptional activity. This suggests that Pax6 binding to the proximal promoter element $G 1$ is required for insulin responsiveness conferred to the truncated promoter by G2.

The requirement of Pax6 in the repression of the glucagon gene transcription by insulin was also shown by the mutation of the Pax6 binding sites within G3, G1, and G3 plus G1. In all three cases mutations decreased basal transcriptional activity and markedly reduced inhibition by insulin of the glucagon promoter. Finally, when an expression vector encoding a GAL4-Pax6 fusion protein was transfected together with -350 (mutG1/G3)GluLuc, basal transcriptional activity of the doubly mutated glucagon promoter was raised to a level similar to that of the wild-type promoter. Importantly, the activity mediated by the GAL4-Pax6 was inhibited by insulin to the levels similar of the wild-type glucagon promoter. This effect of GAL4-Pax6 seems to be specific and also not secondary to the restoration of the basal activity, because the expression of GAL4-VP16 restored basal activity of the doubly mutated glucagon promoter but did not confer insulin responsiveness. When taken together these results suggest that Pax 6 is not sufficient but required for insulin responsiveness of the glucagon promoter.

\subsection{Regulation of Pax6 activity by insulin-induced signalling pathways.}

Pax6 confers insulin response to the glucagon promoter. Inspection of the Pax6 sequence revealed a putative protein kinase $B(P K B)$ phosphorylation site in the Cterminal part of the transactivation domain. It posed the possibility that Pax6 might be directly regulated by the insulin signallig pathways - particularly by PKB. Few examples exist of transcriptional factors which are regulated directly by insulinactivated pathways as has been shown for FKHR (Tang et al. 1999, Rena et al. 1999) and AFX (Geert et al. 1999). In case of FKHR, which is implicated in the transactivation of IGFBP-1 gene, insulin activates PKB which phosphorylates FKHR 
at three conserved sites. This phosphorylation promotes nuclear exclusion of FKHR and thereby negatively regulates the FKHR-mediated transcription (Biggs et al. 1999). Negative regulation by PKB of FKHR-dependent genes involved in promoting apoptosis has been shown as well (Tang et al. 1999). However, in InR1G9 cell line Pax6 seems not to be directly affected by insulin-activated signalling pathways - and particularly by PKB. Insulin-induced posttranslational modifications of a transcriptional factor such as phosphorylation can affect DNA-binding pattern or electro-phoretic mobility as has been shown for FKHR (Tang et al. 1999, Rena et al. 1999) or DAF-16 (Ogg et al. 1997). However, as revealed by EMSA using the nuclear extracts from InR1-G9 cells, neither a change in the band pattern nor band intensity was observed upon insulin treatment, which suggests that DNA-binding of Pax6 is not affected by insulin-stimulated pathway(s). Furthermore, the insulin treatment had also no effect on the expression level of Pax6 protein or its electrophoretic mobility properties as was revealed by Western blotting. These data are consistent with the assumption that Pax6 protein level or posttranslational modifications are not affected by the insulin treatment in InR1-G9 cells.

Finally, these results are supported by an in vitro PKB assay. The immunoprecipitated PKB from InR1-G9 cells treated with insulin did not phosphorylate neither Pax6 paired domain, nor Pax6 full lenght protein (Barthel A., personal communication). This provides a direct evidence that, at least in vitro, Pax6 is not a direct substrate for PKB and might not be regulated by this kinase.

It has been reported recently (Mikkola et al. 1999) that the transactivation domain (TAD) of zebrafish Pax6 is phosphorylated in vitro at three sites by the mitogenacivated protein kinases (MAPKs): extracellular-signal regulated kinase (ERK) and p38 kinase. One of three in vitro phosphorylation sites is strongly conserved in evolution and is also phosphorylated in vivo which stimulates the transactivatory properties of Pax6 TAD. However, the mutation of all three of these sites did not affect the ability of insulin to inhibit Pax6 transcriptional activity in InR1-G9 cells. These findings therefore do not support a role for these mitogen-activated protein kinase phosphorylation sites in insulin action on the glucagon gene.

The negative results presented above considering the regulation of Pax6 by PKB and ERK/p38 do not exclude the possibility that Pax6 might be actually a target for 
these kinases in vivo. However, when taken together, this results do not provide an evidence that Pax6, although crucial for the inhibition of glucagon gene transcription by insulin, is directly targeted by insulin-stimulated signalling pathways in InR1-G9 cells.

\subsection{Inhibition by insulin of the CBP-mediated transcriptional activity.}

The C-terminal transactivation domain of Pax6 is proline/serine/threonine-rich and can interact with the coactivator p300/CBP (Hussain and Habener 1999, Tang et al. 1998), suggesting that recruitment of CBP may be important for the distinct function of Pax6 at the glucagon promoter. The present study shows that transcriptional activity conferred by GAL4-CBP fusion protein to the doubly mutated glucagon promoter was inhibited by insulin. In contrast, insulin did not affect GAL4-CBP activity using a reporter gene with GAL4 binding sites in front of the minimal viral E1B promoter, indicating that the specific glucagon promoter context is required for the effect of insulin on CBP activity. If Pax6 functions through recruitment of CBP, the fact that GAL4-Pax6 but not GAL4-CBP confers insulin responsiveness to the 5xGal4(E1B)Luc reporter gene may be explained by the assumption that CBP might adopt a different conformation and may function differently when bound to the promoter through recruitment by Pax6 or through fusion with the DNA-binding domain of GAL4 (Hu et al. 1999). Different CBP conformation might also induce interaction of $\mathrm{CBP}$ with different cofactors or/and general transcription factors (Korzus et al. 1998, Kurokawa et al. 1998).

CBP and the closely related protein p300 are modular proteins with multiple functional domains (Eckner 1996, Korzus et al. 1998, Kurokawa et al. 1998, Torchia et al. 1998). In addition to Pax6, other transcription factors that bind to the glucagon gene 5'-flanking region can interact with CBP including Beta2/E47/E12 basic helixloop-helix proteins (Mutoh et al. 1998, Qiu et al. 1998), NFATp (Fürstenau et al. 1999, Garcia-Rodriguez and Rao 1998), Ets-like transcription factors (Fürstenau et al. 1997, Yang et al. 1998), and CREB (Oetjen et al. 1994, Knepel et al. 1990, Kwok et al. 1994) (Fig. 21). Interestingly, the functional domains of CBP are differentially used by different transcription factors, implying conformational differences in the CBP-based coactivator complex bound to different classes of transcription factors 
(Korzus et al. 1998, Kurokawa et al. 1998). Thus, through multiple contacts with CBP or through recruiting other coactivators, the specific glucagon promoter context may induce the formation of a promoter-specific nucleoprotein complex (Shikama et al. 1997). Pax6 and CBP may be essential components of such a complex, which integrates the activities of proximal promoter elements and more distal enhancer-like elements and the function of which is sensitive to insulin (this study, Grzeskowiak et al. 2000).

\subsection{Defining the insulin responsive region of CBP.}

Pax6 directly interacts with CBP/p300 proteins (Hussain 1999, Tang 1998) and, as shown in this work, CBP-mediated transcriptional activity is negatively regulated by insulin in glucagon promoter context-specific manner. In the mapping of the CBP protein performed in the present study the $\mathrm{N}$-terminal and $\mathrm{C}$-terminal parts (aminoacids 1-451 and 1892-2441 respectively) conferred strong basal activity and insulin responsiveness. Conversely, the middle part (aminoacids 1061-1891) was rather a poor transactivator and its activity was not inhibited by insulin. These results suggest that $\mathrm{N}$ - and $\mathrm{C}$-terminal domains of CBP protein are sufficient to confer the negative regulation by insulin. The molecular mechanism underlying inhibition by insulin of the activity mediated by the $\mathrm{N}$ - and $\mathrm{C}$-terminal parts of CBP can be speculated to depend on the CBP-interacting cofactor/coactivator proteins. The $\mathrm{N}$-, and C-terminal parts of CBP have been shown to interact with many cofactors involved in the process of transactivation (Shikama et al. 1997). Many of them, like $\mathrm{p} / \mathrm{CAF}$ or $\mathrm{p} / \mathrm{CIP}$, are involved in a very precise and specific modulation of the CBP activity and conferring signals from signalling cascades or transcriptional factors to the general transcriptional machinery (Shikama et al. 1997, Perssi et al. 1999, Martinez-Balbás et al. 1998, Hu et al. 1999). The $\mathrm{N}$ - and C-terminal parts might in this view present an interacting platform for many cofactors which in turn allow the insulin-induced cascade to affect the general transcriptional machinery.

Inspection of the CBP sequence revealed a consensus phosphorylation site for protein kinase $\mathrm{B}$ residing in the $\mathrm{C}$-terminal part. Further mapping was therefore focused on this region and C-terminal part of CBP was subject to several $\mathrm{C}$-, $\mathrm{N}$ terminal and internal deletions. The transcriptional activity conferred by different parts 
was highly variable and might be explained by the modular constitution of CBP (Eckner 1996, Korzus et al. 1998, Kurokawa et al. 1998, Torchia et al. 1998). In this view the transcriptional activity of CBP would be a net output of inhibitory and stimulatory activities of many subdomains. Furthermore, the degree of insulin inhibition was highly correlated with the levels of transcriptional activity. Constructs with low transcriptional activity were also least inhibited by insulin. In the present study however, a single, smallest CBP region was mapped which is capable to confer both transcriptional activity and high degree of insulin inhibition (49\%). This region resides between amino acids 2040 and 2170 and contains the p/CIPinteracting domain. Furthermore, the internal deletion of this sequence (1678$2441^{\Delta 2040-2170}$ ) markedly reduced basal activity and insulin response. These results provide an evidence that CBP region between amino acids 2040 and 2170 is sufficient to confer the negative regulation by insulin. The fact that this domain of CBP interacts with $p /$ CIP poses an interesting speculation that actually this cofactor might be affected by insulin-induced pathway and regulate transcription directly or by modulating the activity of CBP. Recently p/CIP has been shown to regulate the CBP function by modulating its acetyltransferase activity in a substrate selective fashion (Perissi et al. 1999). Such effects were in turn speculated to be regulated by other cellular factors or by postranslational modifications, which provides and example how insulin-induced pathway might target $\mathrm{p} / \mathrm{CIP}$ or/and $\mathrm{CBP}$, and ultimately regulate transcription.

Interestingly, the mapping of the $\mathrm{CBP}$ C-terminal domain revealed that the consensus PKB phosphorylation site is dispensable for the negative regulation by insulin. This does not exclude the possibility that CBP might be phosphorylated in vivo by PKB. Also CBP might be regulated by other kinase(s) along the insulin signalling pathway(s) as has been shown for the regulation by calcium of activity conferred by CBP mutant with deleted CAM kinase site (Hu et al. 1999).

\subsection{Regulation of the CBP activity by PKB.}

The role of $\mathrm{PKB}$ in the regulation of the CBP-mediated transcriptional activity was addressed by overexpression of a constitutively active form of PKB, the myrPKB. Consistent with the previous findings, the activity conferred by the full length, $\mathrm{N}$ - 
terminal (1-451) and part of C-terminal domain (2040-2170) of CBP was inhibited by insulin treatment. Noteworthy, a similar or even stronger inhibition effect was observed when the myrPKB was overexpressed. The overexpression of the myrPKB also inhibited the $-350 \mathrm{GluLuc}$ activity which agrees with previous observations (Dellas $\mathrm{C}$, personal communication). These results suggest that PKB can regulate the CBP-mediated activity and can mimic the negative regulation of the glucagon gene transcription by insulin.

The subdomains of CBP which activity is inhibited by overexpression of the myrPKB do not contain the consensus PKB phosphorylation site. Although this does not exclude the possibility that these domains might still be phosphorylated by PKB in vivo, it might suggest that a direct target for the insulin action is in fact a cofactor(s) of $\mathrm{CBP}$ or synergizing interaction between $\mathrm{CBP}$ and cofactors rather than the CBP molecule itself.

\subsection{Final concept: Inhibition of glucagon gene transcription by insulin through IRE-binding factor(IRF)-independent mechanism.}

Recently a novel and an interesting model has been proposed in which insulin inhibits gene transcription through an IRE-independent mechanism (Leahy 1999, Pierreux et al. 1998, Pierreux et al. 1999, Yeagley et al. 1998). In glucocorticoidinduced 6-phosphofructo-2-kinase (PFK-2) gene transcription (Pierreux et al. 1998, Pierreux et al. 1999) and in cAMP-induced PEPCK gene transcription (Yeagley et al. 1998) it has been shown that in each case a combination of several DNA elements and interacting transcription factors, called glucocorticoid or cAMP response unit, respectively, are required for both full responsiveness to the respective stimulus and inhibiton by insulin. Site-directed mutational analysis revealed that none of the factors seems to be individually involved in the inhibitory effect of insulin (Pierreux et al. 1998, Pierreux et al. 1999, Yeagley et al. 1998). This led to the conclusion that the unique array of factors may be recognized, or stabilized, by a specific coactivator complex and that inhibition of gene transcription by insulin may result from the disruption of this higher order complex (Pierreux et al. 1998, Pierreux et al. 1999, Yeagley et al. 1998). 
Evidence suggests that CBP is part of this complex on the PEPCK promoter (Leahy et al. 1999, Pierreux et al. 1998, Pierreux et al. 1999, Yeagley et al. 1998) and this might also hold true for PFK-2 (Pierreux et al. 1999). The finding that the mitogenregulated $\mathrm{S} 6$ kinase $\mathrm{pp} 90^{\mathrm{RSK}}$ binds to the $\mathrm{C} / \mathrm{H} 3$ region of $\mathrm{CBP}$ and regulates $\mathrm{CBP}$ function (Nakajima et al. 1996) gives an example how an intermediate in a signaling cascade is able to interact with CBP and control gene transcription.

The results of the present study support this concept. Insulin responsiveness of the glucagon promoter was suggested to be dependent on the synergistic interaction between proximal promoter and more distal enhancer-like elements (Grzeskowiak et al. 2000). Pax6 binding to both promoter (G1) and enhancer (G3) elements presents a crucial integrating factor and is required for the insulin responsiveness.

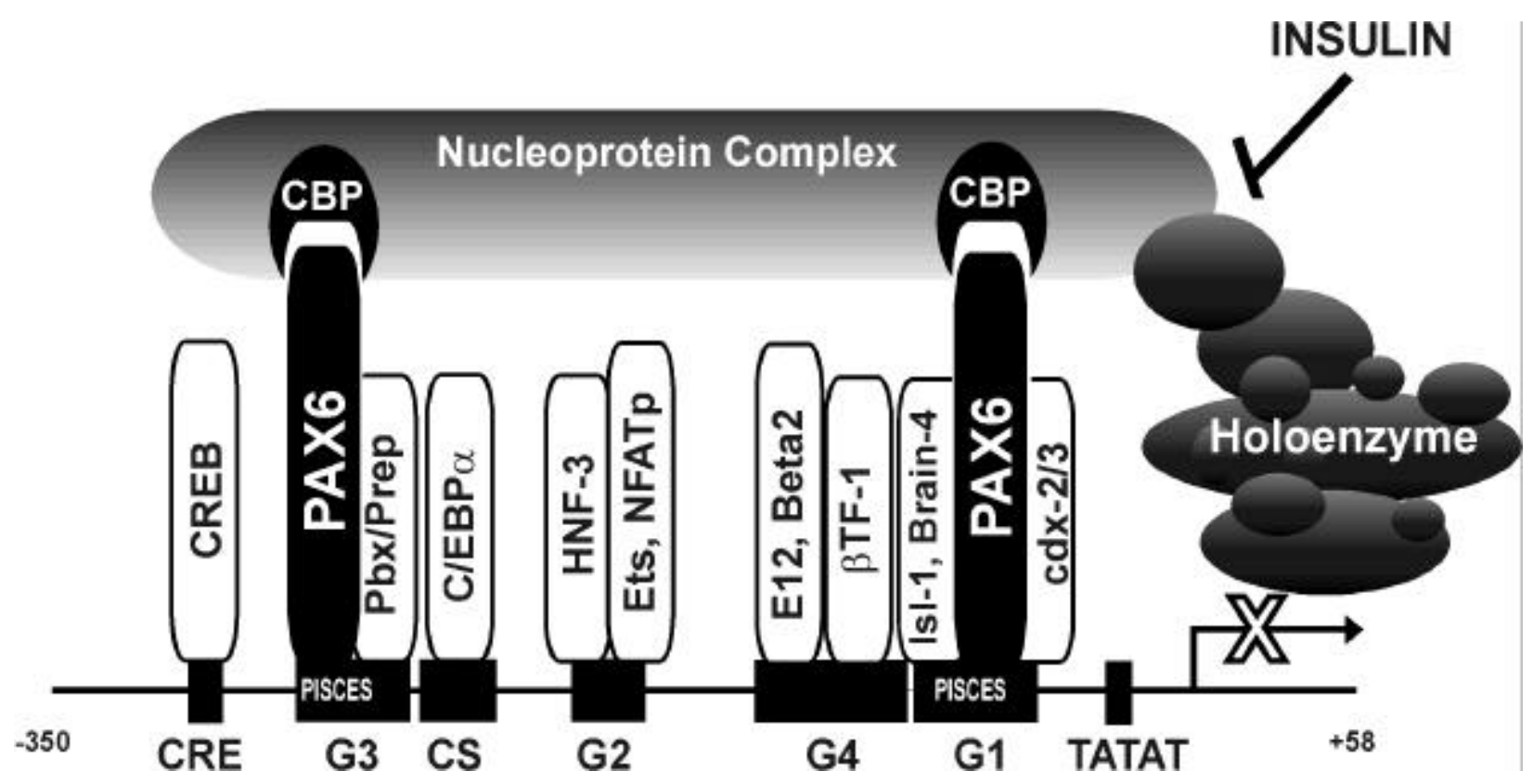

Fig. 21. The importance of Pax6 and CBP in the insulin responsiveness of the glucagon promoter. Schematically presented are regulatory elements of the glucagon promoter and their transcriptional factors. The transcription factors which were reported to interact with CBP are enlarged (CREB, ETS/NFATp, E12/Beta2). Pax6 is shown to bind to PISCES within G1 and G3 elements and interact with CBP which in turn is a part of the large nucleoprotein complex. Insulin stimulus disrupts interaction between the holoenzyme and the nucleoprotein complex which inhibits transactivation of the glucagon gene transcription. 
Pax6 interacts with the coactivator protein CBP, activity of which has been also shown in this study to be regulated by insulin. CBP is a well established integrator of signals coming from transcriptional factors and intracellular signalling pathways to the general transriptional machinery and chromatin (Shikama et al. 1997). Furthermore, the CBP-mediated activity can be further modulated by interaction with CBP-specific cofactors, like p/CIP or p/CAF (Shikama et al. 1997, Perssi et al. 1999). It is therefore tempting to speculate that within the specific context of the glucagon promoter a nucleoprotein complex is being induced. Critical role in establishing this complex might play the interaction of Pax6 with the CBP/p300 coactivator (Fig. 21). In this view insulin might target this large, glucagon promoter-specific protein complex rather than any single transcriptional factor and therefore act through a IRE-binding factor (IRF)-independent mechanism. 


\section{REFERENCES}

Alessi DR, Andjelkovic M, Cron N, Hemmings BA (1996) Mechanisms of activation of protein kinase $B$ by insulin and IGF-1. EMBO J 15:6541-51

Alessi DR, James SR, Downes, Cohen P (1997) Purification and characterisation of a phosphatidylinositol 3,4,5 triphosphate dependent kinase (PDK1) that phosphorylates and activates protein kinase B alpha. Curr Biol 7:261-9

Alexander-Bridges M, Mukhopadhyay NK, Jhala U, Denaro M, Kong X F, Avruch J, and Maller J (1992) Growth factor-activated kinases phosphorylate IRE-ABP Biochem Soc Trans 20:691-3

Andersen FG, Heller RS, Petersen HV, Jensen J, Madsen OD, and Serup P (1999) Pax6 and $C d x 2 / 3$ form a functional complex on the rat glucagon gene promoter G1-element FEBS Lett 445:306-10

Andjelkovic M, Alessi DR, Meier R, Fernandez A, Lamb NJC, Frech M, Cron P, Cohen PP, Lucocq JM and Hemmings BA (1997) Role of Translocation in the activation and Function of Protein Kinase B. J Biol Chem 272:31515-24

Assan R, Attali JR, Ballerio G, Boillot J, Girard JR (1977) Glucagon secretion induced by natural and artificial amino acids in the perfused rat pancreas Diabetes 26:300-7

Barroso I and Santisteban P (1999) Insulin-induced early growth response gene (Egr-1) mediates a short term repression of rat malic enzyme gene ranscription $J$ Biol Chem 274:17997-18004

Beimesche S, Neubauer A, Herzig S, Grzeskowiak R, Diedrich T, Cierny I, Scholz D, Alejel T, and Knepel W (1999) Tissue-specific transcriptional activity of a pancreatic islet cell-specific enhancer sequence/Pax6-binding site determined in normal adult tissues in vivo using transgenic mice. Mol Endocrinol 13:718-28

Berk AJ (1999) Activation of RNA polymerase II transcription. [Review article] Current Opinion in Cell Biology 11:330-5

Biggs WH, Meisenhelder J, Hunter T, Cavenee WK, and Arden KC (1999) Protein kinase B/Akt-mediated phosphorylation promotes nuclear exclusion of the winged helix transcription factor FKHR PNAS 96:7421-6

Bonner-Weir S (1991) Anatomy of the islet of Langerhans. In Samols E (Ed), The endocrine pancreas, Raven Press, New York 
Brown JC (1971) A gastric inhibitory polypeptide II The complete amino acid sequence. Can J Biochem 49:255-61

Brunet A, Bonni A, Zigmond MJ, Lin MZ, Juo PJ, Hu LS, Anderson MJ, Arden K, Blenis CJ and Greenberg ME (1999) Akt promotes cell survival by phosphorylating and inhibiting a Forkhead transcription factor. Cell 96:857-68

Burgering BMT, Coffer PJ (1995) Protein kinase B in phosphatidylinositol 3-kinase signal transductio. Nature 376:599-602

Chapman SC, Ayala JE, Streeper RS, Culbert AA, Eaton EM, Svitek CA, Goldman J K, Tavaré JM and O'Brien RM (1999) Multiple promoter elements are required for the stimulatory effect of insulin on human collagenase-1 gene transcription Selective effects on activator protein-1 expression may explain the quantitative difference in insulin and phorbol ester action. J Biol Chem 274:18625-34

Cheatham B and Kahn R (1995) Insulin action and the insulin signalling network Endocrine Reviews 16:117-42

Chrivia JC, Kwok RPS, Lamb N, Hagiwara M, Montminy M, Goodman RH (1993) Phosphorylated CREB Binds to the Nuclear Protein CBP. Nature 365: 855-859

Cohen P, Alessi DR, Cross DAE (1997) PDK1, one of the missing links in insulin signal transduction? FEBS Letters 410:3-10

Cross DAE, Alessi DR, Cohen P, Hemmings BA (1995) Inhibition of glycogen synthase kinase- $3 \beta$ by insulin mediated protein kinase B. Nature 378:785-9

Datta SR, Dudek H, Tao X, Greenberg ME (1997) Akt phosphorylation of BAD couples survival signals to the cell-intrinsic death machinery. Cell 91:231-41

Deprez J, Vertommen D, Alessi DR, Rider MH (1997) Phosphorylation and activation of heart 6-phosphofructo-2-kinase by protein kinase B and other kinases of the insulin signalling cascade. J Biol Chem 272:17269-75

Downward J (1998) Mechanisms and consequences of activation of protein kinase B/Akt. Current Opinion in Cell Biology 10:262-7

Drucker DJ (1998) Glucagon-like peptides. Diabetes 47:159-69

Drucker DJ, Asa S (1988) Glucagon gene expression in vertebrate brain. J Biol Chem 263:13475-8

Durham SK, Suwanichkul A, Scheimann AO, Yee D, Jackson JG, Barr FG and Powell DR (1999) FKHR binds the insulin response element in the insulin-like growth factor binding protein-1 promoter. Endocrinology 140:3140-6

Eckner R (1996) p300 and CBP as transcriptional regulators and targets of oncogenic events. Biol Chem 377:685-8 
Epstein JA, Glaser T, Cai J, Jepeal L, Walton DS, Maas RL (1994) Two independent and interactive DNA-binding subdomains of the Pax6 paired domain are regulated by alternative splicing. Genes Dev 8:2022-34

Fürstenau U, Schwaninger M, Blume R, Kennerknecht I and Knepel W (1997) Characterization of a novel protein kinase $\mathrm{C}$ response element in the glucagon gene. Mol Cell Biol 17:1805-16

Fürstenau U, Schwaninger M, Blume R, Jendrusch EM, Knepel W (1999) Characterisation of a novel calcium response element in the glucagon gene. $J$ Biol Chem 274:5851-60

Garcia-Rodriguez C and Rao A (1998) Nuclear factor of activated T cells (NFAT)dependent transactivation regulated by the coactivators p300/CREB-binding protein (CBP). J Exp Med 187:2031-6

Geert JPL, Kops ND, de Ruiter AM, Vries DR, Burgering MT (1999) Direct control of the forkhead transcription factor AFX by protein kinase B. Nature 398:630-4

Gerich JE, Schneider V, Dippe SE, Langlois M, Noacco C, Karam JH, Forsham PH (1974) Characterization of the glucagon response to hypoglycemia in man. J Clin Endocrinol Metab 38:77-82

Giordano A, Avantaggiati ML (1999) p300 and CBP: partners for life and death. J Cell Physiol 181:218-30

Glass CK, and Rosenfeld MG (2000) The coregulator exchange in transcriptional functions of nuclear receptors. Genes Dev 14:121-41

Grzeskowiak R, Amin J, Oetjen E, and Knepel W (2000) Insulin responsiveness of the glucagon gene conferred by interactions between proximal promoter and more distal enhancer-like elements involving the paired-domain transcription factor Pax6. J Biol Chem in press

Habener JF, Drucker DJ, Mojsov S, Knepel W, Philippe J (1991) Biosynthesis of glucagon. In: Samols E, ed The endocrine pancreas New York: Raven Press, 5371

Herzig S, Füzesi L, and Knepel W (2000) Heterodimeric Pbx-Prep1 Homeodomain Protein Binding to the Glucagon Gene Restricting Transcription in a Cell Typedependent Manner. J Biol Chem, in press

Hu SC, Chrivia J, Ghosh A (1999) Regulation of CBP-mediated transcription by neuronal calcium signaling. Neuron 22:799-808

Hussain MA, LeeJ, Miller CP, and Habener JF (1997) POU domain transcription factor brain 4 confers pancreatic alpha-cell-specific expression of the proglucagon gene through interaction with a novel proximal promoter G1 element. Mol Cell Biol 17:7186-94 
Hussain MA, and Habener JF (1999) Glucagon gene transcription activation mediated by synergistic interactions of pax-6 and cdx-2 with the p300 co-activator $J$ Biol Chem 274:28950-7

James R, Erier T and Kazenwadel J (1994) Structure of the murine homeobox gene cdx-2: expression in embryonic and adult intestinal epithelium. J Biol Chem 269: 15229-37

Janknecht R and Nordheim A (1993) Gene regulation by ets proteins. Slochim Blophys Acta 1155:346-56

Jin T and Drucker DJ (1996) Activation of proglucagon gene transcription through a novel promoter element by the caudal-related homeodomain protein cdx-2/3. $\mathrm{Mol}$ Cell Biol 16:19-28

Kasuga M, Zick Y, Blith DL, Karlsson FA, Häring HU, Kahn CR (1982) Insulin stimulation of phosphorylation of the beta subunit of the insulin receptor. $J$ Biol Chem 257:9891-4

Kaufmann E and Knöchel W (1996) Five years on the wings of fork head. Mech Dev 57:3-20

Kellerer M, Lammers H, Häring U (1999) Insulin signal transduction: possible mechanisms for insulin resistance. Exp Clin Endocrinol Diabetes 107:97-106

Knepel W, Chafitz J, and Habener JF (1990a) Transcriptional activation of the rat glucagon gene by the cyclic AMP-responsive element in pancreatic islet cells. $\mathrm{Mol}$ Cell Biol 10:6799-804

Knepel W, Jepeal L, and Habener JF (1990b) A pancreatic islet cell-specific enhancer-like element in the glucagon gene contains two domains binding distinct cellular proteins. J Biol Chem 265:8725-35

Knepel W, Vallejo M, Chafitz JA, and Habener JF (1991) The pancreatic islet-specific glucagon G3 transcription factors recognize control elements in the rat somatostatin and insulin-I genes. Mol Endocrinol 5:1457-66

Knepel W (2000) in Molecular Basis of Endocrine Pancreas Development and Function (Hussain, M A, Miller, C P, and Habener, J F, eds) in press, Kluwer Academic Publishers, Boston

Kohler PO and Bridson WE (1971) Isolation of hormone-producing clonal lines of human choriocarcinoma. J Clin Endocrinol 32:683-7

Kops GJ, de Ruiter ND, De Vries-Smits AM, Powell DR, Bos JL, Burgering BM (1999) Direct control of the Forkhead transcription factor AFX by protein kinase B. Nature 398:630-4 
Korzus E, Torchia J, Rose DW, Xu L, Kurokawa R, Mclnerney EM, Mullen TM, Glass CK, and Rosenfeld MG (1998) Transcription factor-specific requirements for coactivators and their acetyltransferase functions. Science 279:703-7

Krüger M, Schwaninger M, Blume R, Oetien E and Knepel W (1997) Inhibition of CREB and CAMP response element-mediated gene transcription by the immunosuppressive drugs cyclosporin A and FK506 in T cells. NaunynSchmiedeberg's Arch Pharmacol 356:433-40

Kruse F, Rose SD, Swift GH, Hammer RE and MacDonald RJ (1993) An endocrinespecific element is an integral component of an exocrine-specffic pancreatic enhancer. Genes Dev 7:774-86

Kurokawa R, Kalafus D, Oligastro MH, Kioussi C, Xu L, Torcha J, Rosenfeld MG, Glass CK (1998) Differential Use of CREB Binding Protein-Coactivator Complexes. Science 279:700-3

Kwok RPS, Lundblad JR, Chrivia JC, Richards JP, Bächinger HP, Brennan RG, Roberts SGE, Green MR, and Goodman RH (1994) Nuclear protein CBP is a coactivator for the transcription factor CREB. Nature 370:223-6

Kyriakis JM, App H, Avruch J (1992) Raf-1 activates MAP kinase-kinase. Nature 358:417-21

Laser B, Made P, Constant I and Philippe J (1996) The caudal-related homoodomain protein $\mathrm{cdx}-2 / 3$ regulates glucagon gene expression in islet cells. $J$ Biol Chem 271: 28984-94

Leahy P, Crawford DR, Grossmann G, Gronostajski RM, and Hanson RW(1999) CREB binding protein coordinates the function of multiple transcription factors including nuclear factor I to regulate phosphoenolpyruvate carboxykinase (GTP) gene transcription. J Biol Chem 274:8813-22

Lee YC, Asa SL and Drucker DJ (1992) Glucagon gene 5'-flanking sequences direct expression of simian virus 40 large $T$ antigen to the intestine, producing carcinoma of the large bowel in transgenic mice. J Biol Chem 267:10705-08

Lefèbvre PJ (1995) Glucago and diabetes. Diabetes Care 18:715-30

Le-Gouill C, Parent JL, Rola-Pleszczynski M and Stankova J (1994) Analysis of recombinant plasmids by a modified alkaline lysis method Anal Biochem 219:164

Mansouri A, Hallonet M, Gruss P (1996) Pax genes and their roles in cell differentiation and development. Curr Opin Cell Biol 6:851-7

Martinez-Balbás MA, Bannister AJ, Martin K, Haus-Seuffert P, Meisterernst M, Kouzarides T (1998) The acetyltransferase activity of CBP stimulates transcription. The EMBO Journal 17:2886-93 
Meyer TE, Habener JF (1993) Cyclic adenosine 3', 5' - monophosphate response element binding protein (CREB) and related transcription-activating deoxiribonucleic acid-binding proteins. Endocrine Rev 14:269-90

Mikkola I, Bruun J, Bjørkøy G, Holm T, and Johansen T (1999) Phosphorylation of the transactivation domain of Pax 6 by extracellular signal-regulated kinase and p38 mitogen-activated protein kinase. J Biol Chem 274:15115-26

Miller CP, Lin JC and Habener JF (1993) Transcription of the rat glucagon gene by the cyclic AMP response element-binding protein CREB is modulated by adjacent CREB-associated proteins. Mol Cell Biol 13:7080-90

Morell C, Cordier-Bussat M, Philippe J (1995) The upstream promoter element of the glucagon gene, G1, confers alpha cell-specific expression. J Biol Chem 270:304655

Mutoh H, Naya FJ, Tsai MJ, and Leiter AB (1998) The basic helix-loop-helix protein BETA2 interacts with $\mathrm{p} 300$ to coordinate differentiation of secretin-expressing enteroendocrine cells. Genes Dev 12:820-30

Mutt V and Jorpes JE, Magnusson S (1970) Structure of porcine secretin The amino acid sequence. Eur J Biochem 15:513-9

Mutt V and Said SI (1974) Structure of the porcine vasoactive intestinal octacosapeptide The amino-acid sequence Use of kallikrein in its determination. Eur J Biochem 42:581-9

Nakajima T, Fukamizu A, Takahashi J, Gage FH, Fisher T, Blenis J, Montminy MR (1996) The signal-dependent coactivator CBP is a nuclear target for pp90RSK. Cell 86:465-74

Nordeen SK (1988) Luciferase reporter gene vectors for analysis of promoters and enhancers, BioTechniques 6:454-7

O' Brien RM, Lucas PC, Forest CD, Magnuson MA and Granner DK (1990) Identification of a sequence in the PEPCK gene that mediates a negative effect of insulin on transcription. Science 249:533-7

O'Brien RM and Granner DK (1991) Regulation of gene expression by insulin. Biochem J 278:609-19

O'Brien RM and Granner DK (1996) Regulation of gene expression by insulin Physiological Reviews 76:1109-60

Oetjen E, Diedrich T, Eggers A, Eckert B, and Knepel W (1994) Distinct properties of the cAMP-responsive element of the rat insulin I gene. J Biol Chem 269:27036-44 
Ogg S, Paradis S, Gottieb S, Patterson GI, Lee L, Tissenbaum HA and Ruvkun G (1997) The forkhead transcription factor DAF-16 transduces insulin-like metabolic and longevity signals in C elegans. Nature 389:994-9

Orskov C, Hoist JJ, Knuhtsen S, Baidissera FGA, Poulsen SS and Nielsen V (1986) Glucagon-like peptides GLP-1 and GLP-2, predicted products of the glucagon gene, are secreted separately from pig small intestine but not pancreas. Endocrinology 119:1467-75

Ortiz L, Aza-Blanc P, Zannini M, Cato ACB and Santisteban P (1999) The interaction between the forkhead thyroid transcription factor TTF-2 and the constitutive factor $\mathrm{CTF} / \mathrm{NF}-1$ is required for efficient hormonal regulation of the thyroperoxidase gene transcription. J Biol Chem 274:15213-21

Ouyang L, Jacob KK and Stanley FM (1996) GABP mediates insulin-increased prolactin gene transcription. J Biol Chem 271:10425-8

Perissi V, Dasen JS, Kurokawa R, Wang Z, Korzus E, Rose DW, Glass CG, Rosenfeld MG (1999) Factor-specific modulation of CREB-binding protein acetyltransferase activity. Proc Natl Acad Sci USA 96:3652-7

Philippe J, Drucker DJ, Knepel W, Jepeal L, Misulovin Z, Habener JF (1988) Alphacell-specific expression of the glucagon gene is conferred to the glucagon promoter element by the interaction of DNA-binding proteins. Mol Cell Biol 8:487788

Philippe $\mathrm{J}$ (1989) Glucagon gene transcription is negatively regulated by insulin in a hamster islet cell line. J Clin Invest 84:672-7

Philippe $J$ (1991) Insulin regulation of the glucagon gene is mediated by an insulin-responsive DNA element. Proc Natl Acad Sci USA 88:7224-7

Pierreux CE, Urs $\varnothing$ B, De Meyts P, Rousseau GG and Lemaigre FP (1998) Inhibition by insulin of glucocorticoid-induced gene transcription: involvement of the ligand-binding domain of the glucocorticoid receptor and independence from the phosphatidylinositol 3-kinase and mitogen-activated protein kinase pathways. Mol Endocrinol 12:1343-54

Pierreux CE, Rousseau GG and Lemaigre FP (1999) Insulin inhibition of glucocorticoid-stimulated gene transcription: requirement for an insulin response element? Mol Cell Endocrinol 147:1-5

Qiu Y, Sharma A and Stein R (1998) p300 mediates transcriptional stimulation by the basic helix-loop-helix activators of the insulin gene. Mol Cell Biol 18:2957-64

Rao A (1994) NF-ATP: a transcription factor required for the co-ordinate induction of several cytokine genes. Immunol Today 15:274-81 
Rena G, Guo S, Cichy SC, Unterman TG, Cohen P (1999) Phosphorylation of the transcription factor forkhead family member FKHR by protein kinase B. $J$ Biol Chem 274:17179-83

Ritz-Laser B, Estreicher A, Klages N, Saule S, and Philippe J (1999) Pax-6 and Cdx$2 / 3$ interact to activate glucagon gene expression on the $\mathrm{G} 1$ control elementJ Biol Chem 274:4124-32

Roberts SGE and Green MR (1994) Activator-induced conformational change in general transcription factor TFIIB Nature 371:717-19

Roichlin S (1983) Somatostatin. N Engl J Med 309:1495-1501

Sadowski I and Ptashne M (1989) A vector for expressing GAL4(1-147) fusions in mammalian cells. Nucleic Acids Res 17:7539

Sambrook J, Fritsch EF and Maniatis T (1989) Molecular cloning. A laboratory manual. 2-nd Edition Cold Spring Harbor Laboratory

Samols E, Weir GC, Bonner-Weir S (1983) in Handbook of experimental pharmacology. (Lefebvre PJ ed) 66:133-173 Springer-Verlag, New York

Sander M, Neubüser A, Kalamaras J, Ee HC, Martin GR, German MS (1997) Genetic analysis reveals that Pax6 is required for normal transcription of pancreatic hormone genes and islet development. Genes Dev 11:1662-73

Schwaninger M, Lux G, Blume R, Oetlen E, Hidaka H and Knepel W (1993) Membrane depolarization and calcium influx induce glucagon gene transcription in pancreatic islet cells through the cyclic AMP-responsive element. $J$ Biol Chem 268: $5168-77$

Shah P, Basu A, Basu R, Rizza R (1999) Impact of lack of suppression of glucagon on glucose tolerance in humans. Am J Physiol 277:283-90

Shaw M, Cohen P, Alessi DR (1997) Further evidence that the inhibition of glycogen synthase kinase-3beta by IGF-1 is mediated by PDK-1/PKB-induced phosphorylation of Ser-9 and not by dephosphorylation of Tyr-216. FEBS Lett 416:307-11

Shikama N, Lyon J, La Thangue NB (1997) The p300/CBP family: integrating signals with transcription factors and chromatin. (review) Trends in Cell Biology 7:230-6

Slack JMW (1995) Developmental biology of the pancreas. Development 121:156980

Spiess J, Rivier J, Thorner M, Vale W (1982) Sequence analysis of a growth hormone releasing factor from a human pancreatic islet tumor. Biochemistry $21: 6037-40$ 
Stokoe D, Stephens LR, Reese CB, Hawkins PT (1997) Dual role of phosphatidylinositol $3,4,5$ triphosphate in the activation of protein kinase $\mathrm{B}$. Science 277:567-70

St-Onge L, Sosa-Pineda B, Mansouri A and Gruss P (1997) Pax6 is required for differentiation of glucagon-producing alpha-cells in mouse pancreas Nature 387:406-9

Strachan T and Read AP (1994) PAX genes. Curr Opin Genet Dev 4:427-38

Streeper RS , Chapman SC, Ayala JE, Svitek CA, Goldmann JK, Cave A and O'Brien RM (1998) A phorbol ester-insensitive AP-1 motif mediates the stimulatory effect of insulin on rat malic enzyme gene transcription. Mol Endocrinol 12:177891

Takaki R, Ono J, Nakamura M, Yokogawa Y, Kumae S, Hiraoka T, Ymaguchl K, Hamaguchi $K$ and Uchida S (1986) Isolation of glucagon-secreting cell lines by cloning insulinoma cells. In Vitro Cell Dev Biol 22:120-6

Tang ED, Nuñez G, Barr FG, Guan KL (1999) Negative regulation of the forkhead transcription factor FKHR by Akt. J Biol Chem 274:16741-6

Thaws G, Mutschier E and Vaupol P (1991) Anatomie, Physiologie, Pathophysiologie des Menschen. 4 Auflage Wissenschaftliche Verlagsgeselischaft, Stuttgart

Thompson, M J, Roe, M W, Malik, R K, and Blackshear, P J (1994) Insulin and other growth factors induce binding of the ternary complex and a novel protein complex to the c-fos serum response element. J Biol Chem 269:21127-35

Throsby M, Homo-Delarche F, Chevenne D, Goya R, Dardenne M, Pleau JM (1998) Pancreatic hormone expression in the murine thymus: localization in dendritic cells and macrophages. Endocrinology 139:2399-406

Torchia J, Glass C, and Rosenfeld MG (1998) Co-activators and co-repressors in the integration of transcriptional responses. Curr Opin Cel Biol 10:373-83

Turque N, Plaza S, Radvanyi F, Carriere C, Saule S (1994) Pax-QNR/Pax6, a paired box- and homeobox-containing gene expressed in neurons, is also expressed in pancreatic endocrine cells. Mol Endocrinol 8:929-38

Uesugi M, Nyanguile O, Lu H, Levine AJ and Verdine GL (1997) Induced alpha helix in the VP16 activation domain upon binding to a human TAF. Science 277:131013

Unger RH and Orci L (1981) Glucagon and the A cell: physiology and pathophysiology. N Eng J Med 304:1518-24 
Utley RT, Ikeda K, Grant PA, Cote J, Steger DJ, Eberharter A, John S, and Workman JL (1998) Transcriptional activators direct histone acetyltransferase complexes to nucleosomes. Nature 394:498-502

Vanhaesebroeck B, Leevers SJ, Panayotou G, Waterfield MD (1997) Phosphoinositide 3-kinases:a conserved family of signal transducers. Trends Biochem Sci 22:267-72

Walther C and Gruss P (1994) Pax-6, a murine paired box gene, is expressedin the developing CNS. Development 113:1435-49

Wang D and Sul HS (1997) Upstream stimulatory factor binding to the E-box at -65 is required for insulin regulation of the fatty acid synthase promoter. $J$ Biol Chem 272:26367-74

Wrege A, Diedrich T, Hochhuth C, and Knepel W (1995) Transcriptional activity of domain $\mathrm{A}$ of the rat glucagon G3 element conferred by an islet-specific nuclear protein that also binds to similar pancreatic islet cell-specific enhancer sequences (PISCES). Gene Expr 4:205-16

Yang C, Shapiro LH, Rivera M, Kumar A, and Brindle PK (1998) A role for CREB binding protein and p300 transcriptional coactivators in Ets-1 transactivation functions. Mol Cell Biol 18:2218-29

Yankulov K, Blau J, Purton T, Roberts S, Bentley DL (1994) Transcriptional elongation by RNA polymerase II is stimulated by transactivators. Cell 5:749-59

Yeagley D, Agati JM and Quinn PG (1998) A tripartite array of transcription factor binding sites mediates CAMP induction of phosphoenolpyruvate carboxykinase gene transcription and its inhibition by insulin. J Biol Chem 273:18743-50 


\section{Acknowledgements}

I am grateful to Prof. Dr. W. Knepel, for giving me the opportunity to work in his laboratory and for his excellent supervision.

I would like to thank Prof. Dr. R. Hardeland and Prof. Dr. K. Jungermann, for acting as referent and co-referent respectively.

I am also thankful to Prof. Dr. G. Burckhardt for his active support during all these years I was a member of the Graduate College 335.

Many thanks to Elke Oetjen for helpful technical and theoretical remarks.

For help and professional technical assistance I thank to Roland Blume and Doris Scholz.

Last but not least, I am thankful to Ulli, Sven and Stephan for stimulating talks (not only scientific) and friendly help in my daily work. 


\section{RESUME}

Name:

Rafal Grzeskowiak

Date of birth:

2. 5.1973

Place of birth:

Szczecin, Poland

Nationality:

Polish

\section{Schools:}

1980-1988

Primary School in Choszczno, Poland

1988-1992

Secondary School in Choszczno, Poland

June 1992

Final Examinations

\section{Study:}

1992-1997

June 1997

Study in the faculty of biology of the University of Warsaw, Poland

Final examination for the degree of M.Sc. in molecular biology

Postgraduate study

September 1997

October 1997

September 2000
Research project in the Department of Molecular Pharmacology in the Pharmacology and Toxicology Centre of Georg-August University (head: Prof. Dr. rer. nat. W. Knepel)

Member of the Graduate College 335 „Klinische, Zelluläre und Molekulare Biologie Innerer Organe“ (supervisor Prof. Dr. med. G. Burckhardt)

Submission of the dissertation 